Historic, Archive Document

Do not assume content reflects current scientific knowledge, policies, or practices. 



\section{FALL 1909 LIBPARY,}

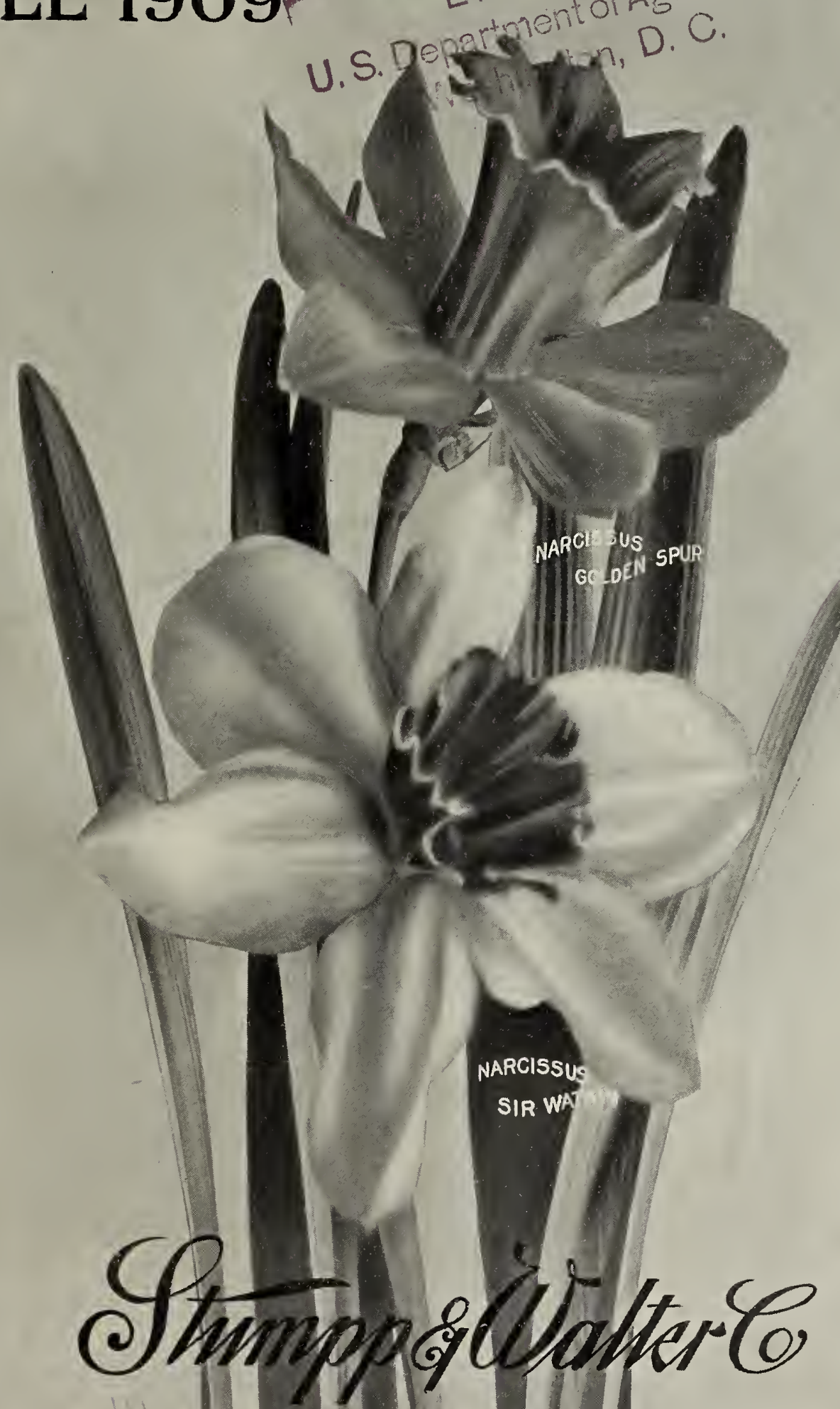

50 BARCLAY STREET,

NEW YORK 


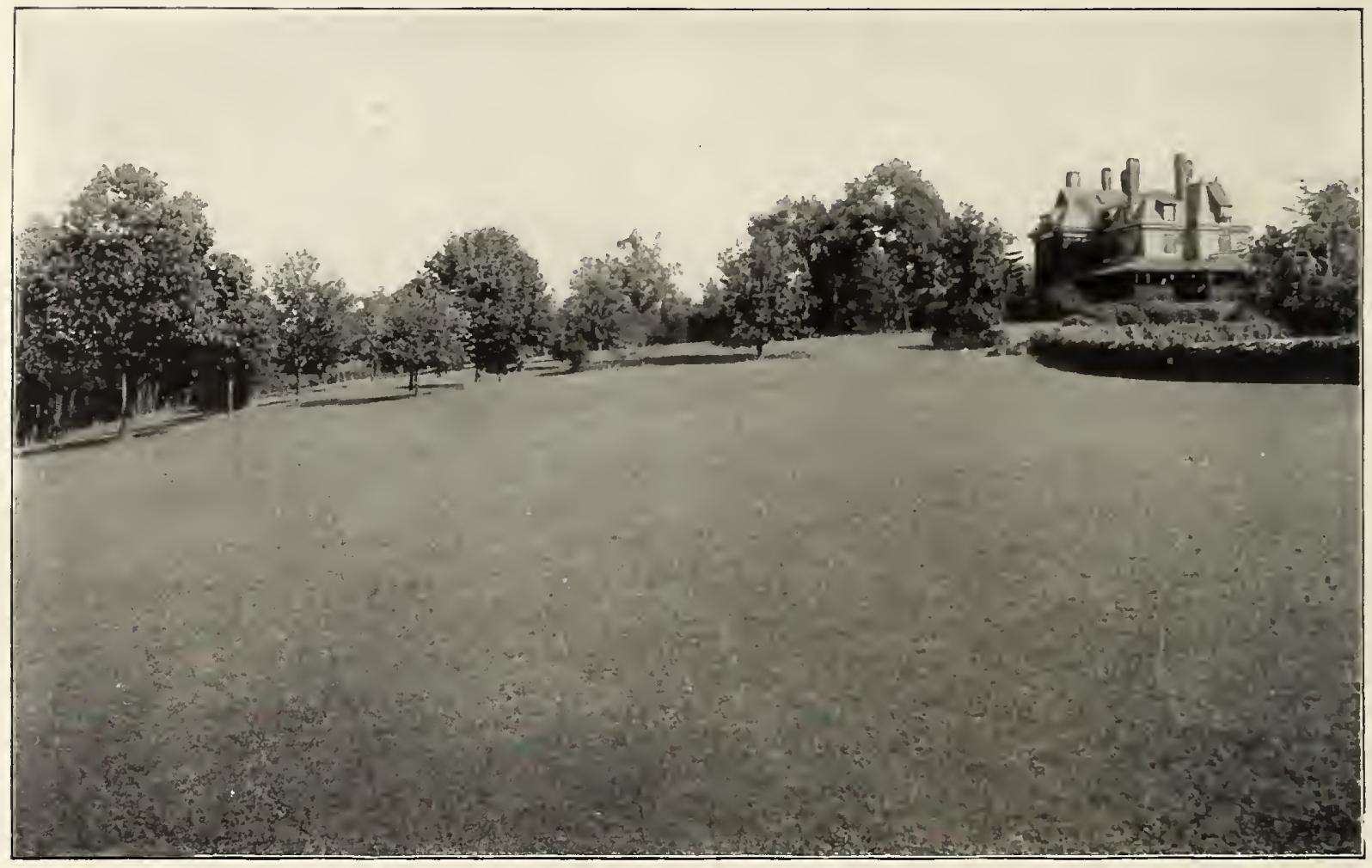

\section{S. \& W. CO.'S HIGH GRADE LAWN GRASS SEED}

This is a mixture of the hardiest, dwarfest growing Grass Seed, and is the result of ten years' constant trial and study to get a mixture of seed that is properly balanced to make a lawn that will withstand oul extreme changes in temperature.

The majority of the mixtures sent out are at their best only part of the season: this is caused by the use of either too few varieties, or the use of too much of some and not enough of other varieties in the mixture.

S. \& W. Co.'s High Grade Lawn Serd is properly balanced, and only the purest, cleanest and best seedsare used.

Price Per Quart, 25c., by Mail Postpaid, 30 c.

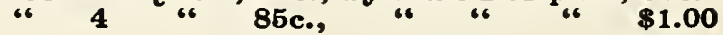

Price 8 Quarts, \$1.50, by Express Prepaid, $\$ 1.75$

“ Per Bushel $\$ 5.00$, by Express Prepaid

\section{S. \& W. CO.'S GRASS SEED MIXTURES FOR HAY AND PERMANERET}

For every different kind and condition of soil there are a large number of grasses, ejther indigenous or introduced, which are especially suitable. Some sorts do best on high ground and in dry weather; others prefer plenty of moisture. Some mature so early and others so late that from the beginning of Spring until Winter sets in there is no time when one species or another is not at its best. From these considerations the importance of sowing many varieties for pasture and meadow purposes will be apparent, consisting of the following varieties: Orchard Grass, Meadow Foxtail, Sheep's Fescue, Rhode Island or Creeping Bent, Hard Fescue, Sweet-Scented Vernal (True Perennial), Mcadow Fescue, English Rye Grass, Italian Rye Grass, Red Top, Timothy and Red Alsike Clover, blended in propontions which we have found from actual use, give the most satisfactory results.

On ordinarily fertile soil three bushels of this mixture are sufficient to seed an acre, but where the land is poor a larger quantity will be necessary. Taking one soil with another, a fair average would be three bushels to the acre.

For Hay and Permanent Pasture For Light Soils

“.

“ Orchard and Shady Places

“ Hay only. Specially recommended for large hay crop

“ Pasture only. Will stand close cropping without injury

$\$ 2.50$ per bushel of $14 \mathrm{lbs}$.

20 bushel lots, $\$ 2.45$ per bushel

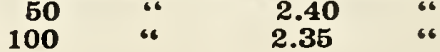

For Wheat, Rye, Clovers and Grasses-see last page. 


\section{Trial Grounds DUMONT, N.J.}

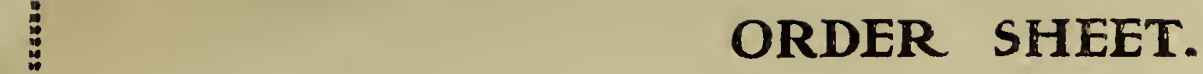

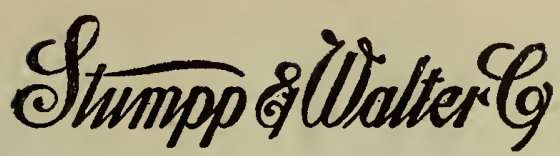

50 Barclay Street

TIRMS. While we exereise the greatest care to have all seeds pure and reliable and all Bulbs and Plants true to name and of best quality

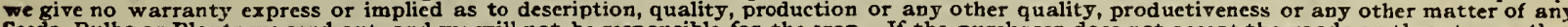

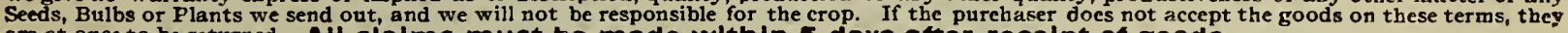
are at once to be returned. All claims must be made within 5 days after recelpt of goods.

\section{Name}

Street or Box No.

Date

Town

AMOUNT ENCLOSED.

County

State 


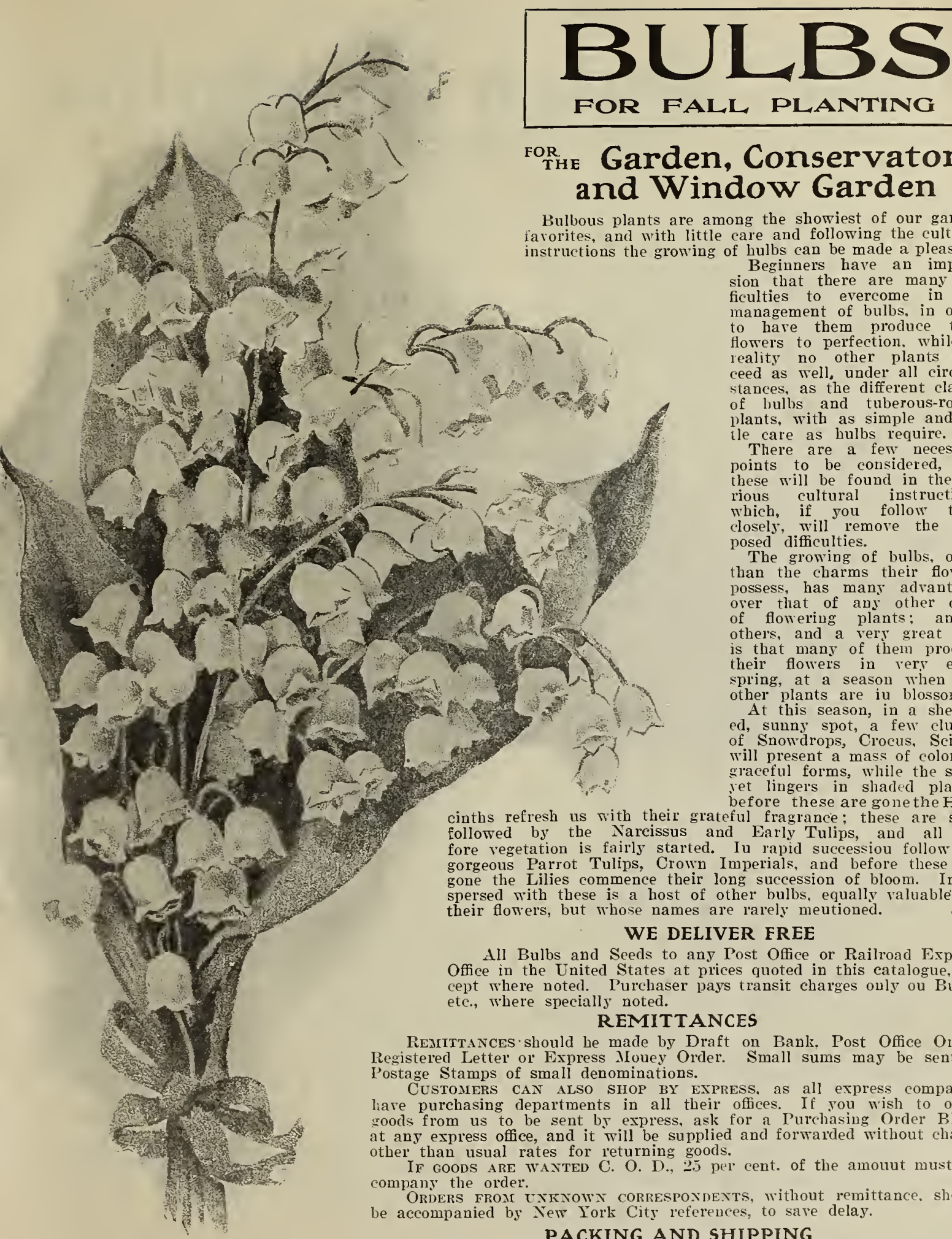

FOR FALL PLANTING

\section{FOR Garden, Conservatory and Window Garden}

Bulbous plants are among the showiest of our garden farorites, and with little care and following the cultural instructions the growing of hulbs can be made a pleasure.

Beginners have an impression that there are many difficulties to evercome in the management of bulbs, in order to have them produce their flower's to perfection. while in reality no other plants succeed as well, under all circumstances, as the different classes of luulbs and tuberous-rooted plants, with as simple and litile care as hulbs require.

There are a few necessary points to be considered, and these will be found in the rarious cultural instructions, which, if you follow them closely, will remove the supposed difficulties.

The growing of bulbs, other than the charms their flowers possess, has many adrantages orer that of any other class of flowering plants: among others, and a very great one, is that many of them produce their flowers in very early spring, at a season when few other plants are iu blossom.

At this season, in a sheltered, sunny spot, a few clumps of Snowdrops, Crocus, Scillas, will present a mass of color, in graceful forms, while the snow ret linger's in shaded places; before these are gone the Hya-

cinths refresh us with their grateful fragrance; these are soon followed by the Narcissus and Early Tulips, and all before regetation is fairly started. In rapid successiou follow the gorgeous Parrot Tulips, Crown Imperials, and before these are gone the Lilies commence their long succession of bloom. Interspersed nith these is a host of other bulbs, equally valuable for their floter's, but whose names are rarely meutioned.

\section{WE DELIVER FREE}

All Bulbs and Seeds to any Post Office or Railroad Express Office in the United States at prices quoted in this catalogue, except where noted. P'urchaser pays transit charges ouly ou Bulbs, etc., where specially noted.

\section{REMITTANCES}

Remittances should he made by Draft on Bank. Post Office Order, Registered Letter or Express ILouey Order. Small sums may be sent in Postage Stamps of small denominations.

CUSTOMERS CAN ALSO SHOP BY EXPRESS, as all express companies liare purchasing departments in all their offices. If you wish to order coods from us to be sent br express, ask for a Purchasing Order Blank at any express office, and it will be supplied and forwarded without charge other than usual rates for returning goods.

If GOODS ARE WANTED C. O. D., 25 per cent. of the amout must accompany the order.

ORDERS FROM UXKNOWX CORRESPONDENTS, without remittance, should be accompanied by New York City references, to sare delay.

\section{PACKING AND SHIPPING}

The make no charge for packing excent for cloth bags, and no chargi for cartage or delivery of goods to any shipping office in New York City.

SAFE ARRIVAL ASSURED. Te guarantee the safe arrival of all Bulbs and Seeds sent by express. Should anything he injured in transit, notify us at once and send us a list of what has becn damaged, so that we can replace such without delay. 


\section{EXTRA SELECTED} NAMED ...
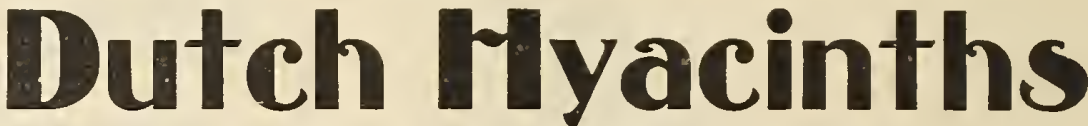

Specially suited for growing in pots or glasses, or for high-class bedding, at a uniform price of $15 \mathrm{c}$. each ; $\$ 1.50$ per doz.; $\$ 10.00$ per 100 . Delivered free anywhere in the United States.

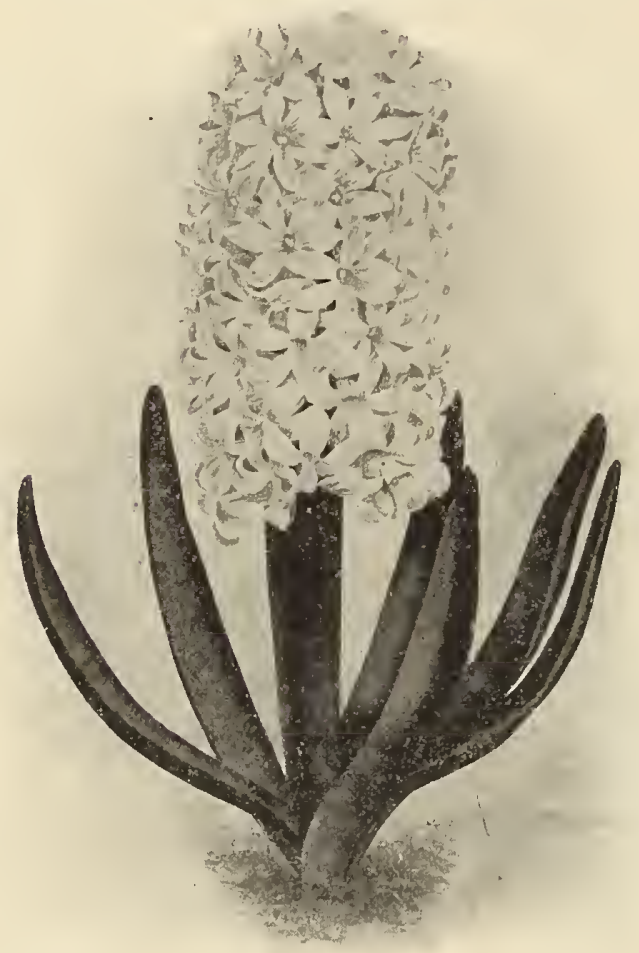

Single Pink Gigantea

The bulbs offered here are first size and best quality grown in Holland.

\section{SINGLE RED AND ROSE HYACINTHS}

Moreno. Waxy pink, early.

William the First. Dark red, fine.

Rosea Maxima. Delicate rose.

Chas. Dickens. Beautiful pink, white shaded, very large truss.

Cardinal Veisman. Fine rose.

Floreuce Nightingale. Light rose, fine spile.

Gertrudle, Rosy pink, large, erect spike, of excentional value for pots or bedding; a splendid forcer.

Gigantea. Rose and blush, large bells, extra largo close truss, one of the best pink hyacinths for either forcing $\mathrm{or}^{\circ}$ bedding.

Iord Maenulay. Rosy carmine, large bells and spike. Ia Ineonluarable. Deep crimson, fine spike.

Robert Steiger. Fine deep crimson, large truss. A very popular variety for either bedding or pot culture.
Roi des Belges. Very large, full spike, fine deep color.

Von Sehiller. Deep salmon pink, striped with erimson, large broad spike, forces easily.

\section{SINGLE PURE AND CREAMY WrIITE HYACINTHS}

Agnes Christina. Pure $w^{\text {hite. }}$

Alba Superbissima. Pure white, large spike, a favorite early variety.

Baroness Ton Thuyll. Snow white, large eompact truss of many bells, splendid for bedding and pnt culture, one of the best for early forcing.

Blanehard. Pure white, early variety.

Grandeur a Merveille. Finest blush white, extra fine large truss; it is the best of this color to grow in quantity.

Ia Franchise. Blush white, large bells, fine for forcing.

La Grandesse. Pure white, long spike, very eompact, excellent for pots or forcing.

L'Innocenee. Pure white, large bells, extra large spike; one of the best forcing varieties.

Mme. Van der Hoop. Pure white, large bells, dwarf spike.

Mr. Plimsoll. Blush white.

Pavillion Blane. Pure waxy white.

Rosseau. Creamy white.

Voltaire. Waxy white.

\section{SINGLE LIGHT AND DARK BLUE HYACINTHS}

Baron von Thuyll. Bright blue.

Blondlin. Beautiful silvery blue, a eompaet large spike; splendid for forcing or bedding.

Chas. Diekens. Light blue, tinted lilac.

Czar Peter. Porcelain blue, extra fine, large spike.

Grand Maitre. Grand large spike, pure ultramarine blue. shaded porcelain, strong grower.

La Peyrouse. Fine light blue, large bells, fine large spike; a splendid variety for bedding out, and a great favorite for forcing, very early.

Leonidas. Light blue, early.

Lord Derby. Light porcelain, one of the finest varieties.

Marie. Deep purple blue, with light blue stripe, extra good compact and large truss; a splendid variety for pots.

Regulus. Fine porcelain blue, large bells, compact and large truss.

King of the lilue's. Rich dark blue, large bells, broad spike; splendid for forcing and pot culture.

Qncen of the Blues. Porcelain, large compact spike, large bells.

\section{SINGLE YELLOW HYACINTHS}

Ida. Pure, the best, yellow:

Sonora. Salmon yellow, early:

ling of the Yellows. Pure bright yellom:

All the above are seleeted first size bulbs, for which we make a uniform price of 15 cts. each: $\$ 1.50$ per doz.; $\$ 10.00$ per 100 . Delivered free anywhere in the $U$. $S$. 


\section{S. E W. Co.'s Mammoth Named Hyacinths}

These bulbs are the largest size and finest varieties imported, and where extra large blooms are wanted for show and exhibition purposes, would recommend trying this stock. The undermentioned 10 varieties consisting of 3 shades of White, 3 shades of Blue, 3 shades of Red and 1 of Yellow, are the 10 best flowering varieties of all the named sorts.

Price, 20 cents each; $\$ \mathbf{2 . 2 5}$ per doz.; $\$ \mathbf{1 5 . 0 0}$ per 100. Delivered free anywhere in the United States.

Barouess Yon Thmyll. Pure white, large fine compact spike.

Grandem a Merveille, Blush white.

Linnocence. Waxy white.

Grand Maitre. Blue shaded porcelain.

Queen of the Blues. Light blue, one of the best pot Hyacinths.

King of the Blues. Dark blue.

Roi des Belges. Fine deep red.

Gertrude. Fine rosy pink.

Gigantea. Light pink.

Obelisque. Large yellow.

The above collection 1 bulb each, 10 varieties for $\$ 2.25 ; 2$ collections for $\$ \mathbf{4 4 . 2 5}$. Delivered free anywhere in the United States.

\section{DOUBLE NAMED MYACINTHS}

Bonquet Royal. Fine rose, dark shaded, very handsome truss.

Bouquet Tendre. Brilliant carmine red, good truss early.

Czar Nicholas. Pale pink, large bells, fine spike.

Prince of Orange. Large, semi-double, light pink, fine spike.

La Tomr d'Avergne. The earliest pure white, extra fine.

Kohinoor. Pink.

Isabella. Fine blush white, large spike.

Lord Raglan. Lilac-blue.

Prince of Waterloo. Pure white, fine spike.

Van Spcyck, Lilac-blue.

Goethe. Light yellow, fine bells, large truss, extra fine.

Jaune Supreme. Splendid rich yellow, tall stiff spike; well furnished with large bells, one of the yellowest, early.

Minerva. Salmon, with rosy carmine stripe, fine double bells, compact rounded spike.

William III. Yellow, tinged orange, rose center, fine compact spike.

Blocksberg. Light blue, marbled, extra large bells, magnificent large compact spike; the finest double light blue, early.

Charles Dickens. Magnificent dark blue, shaded lilac, excellent, large and compact.

All of the above named Domble Hyacinths $15 \mathrm{cts}$. each; $\$ 1.50$ per doz.: $\$ 10.00$ per 100 . Delivered free in the $U$. $S$.

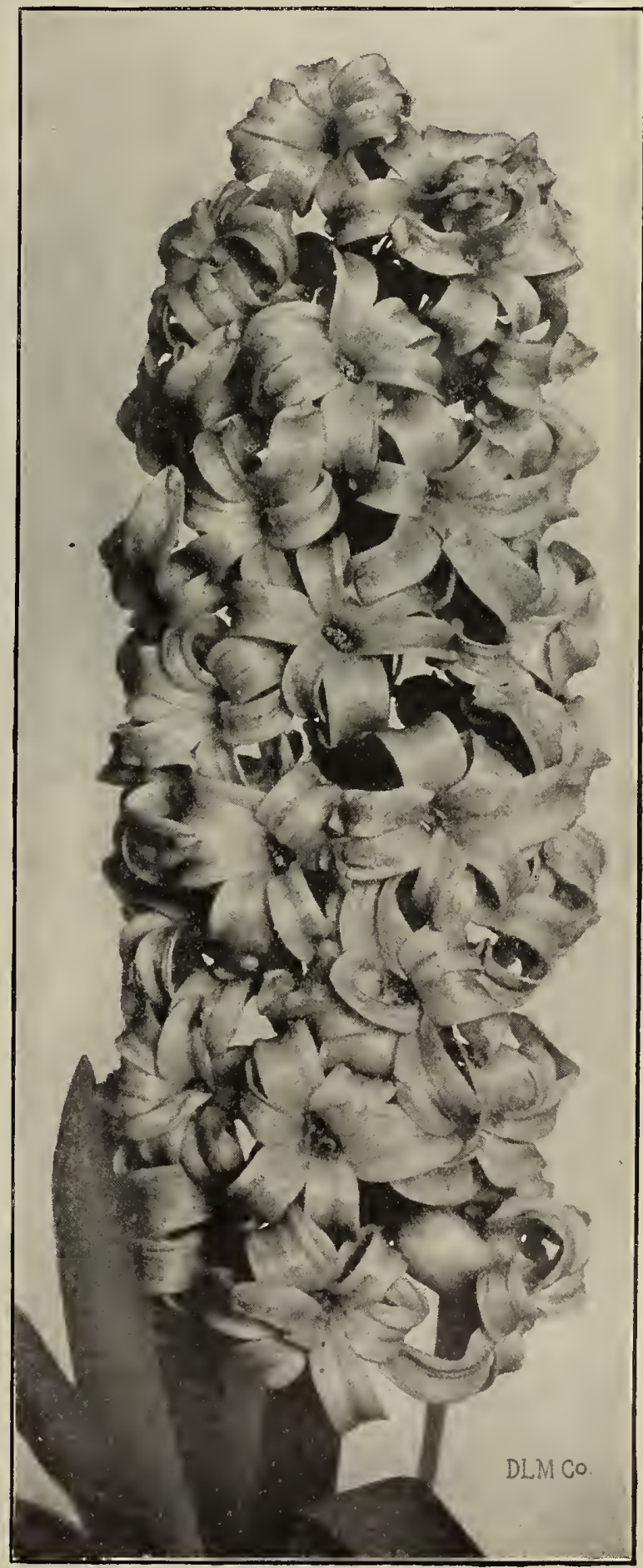




\section{How to Grow Hyacintbs Batdoors.}

For the open border but one condition is absolutely necessary, riz., they must be protected against flost. Although Hyacinths are classed with the hardy bulbs, they are by no means such, and where the bulbs are cultirated for purposes of sale the ground is so thoroughly mulched that the frost rarely, if ever, touches the bulbs

In planting the Hyacinth, no matter what the nature of the soil may bc, make it deep, and work in libcral quantities of well-rotted manure; if it is a heavy loam the bulbs should not be covered more than two inches; if in a light sandy soil, cover them fully four inches. Upon the approach of frost, cover the beds with newly fallen leaves, to the depth of six inches; this covering should be extended at least eighteen inches beyond the bed on all sides, and then kept in place by Evergreen boughs, brush or pleces of boards. Thus protected, the Hyacinth will be among the first plants to put in an appearance above ground in spring.

No further work will be required for the perfect development of the flower. Bulbs slould be planted from 4 to 6 inches deep and about 6 inches apart.

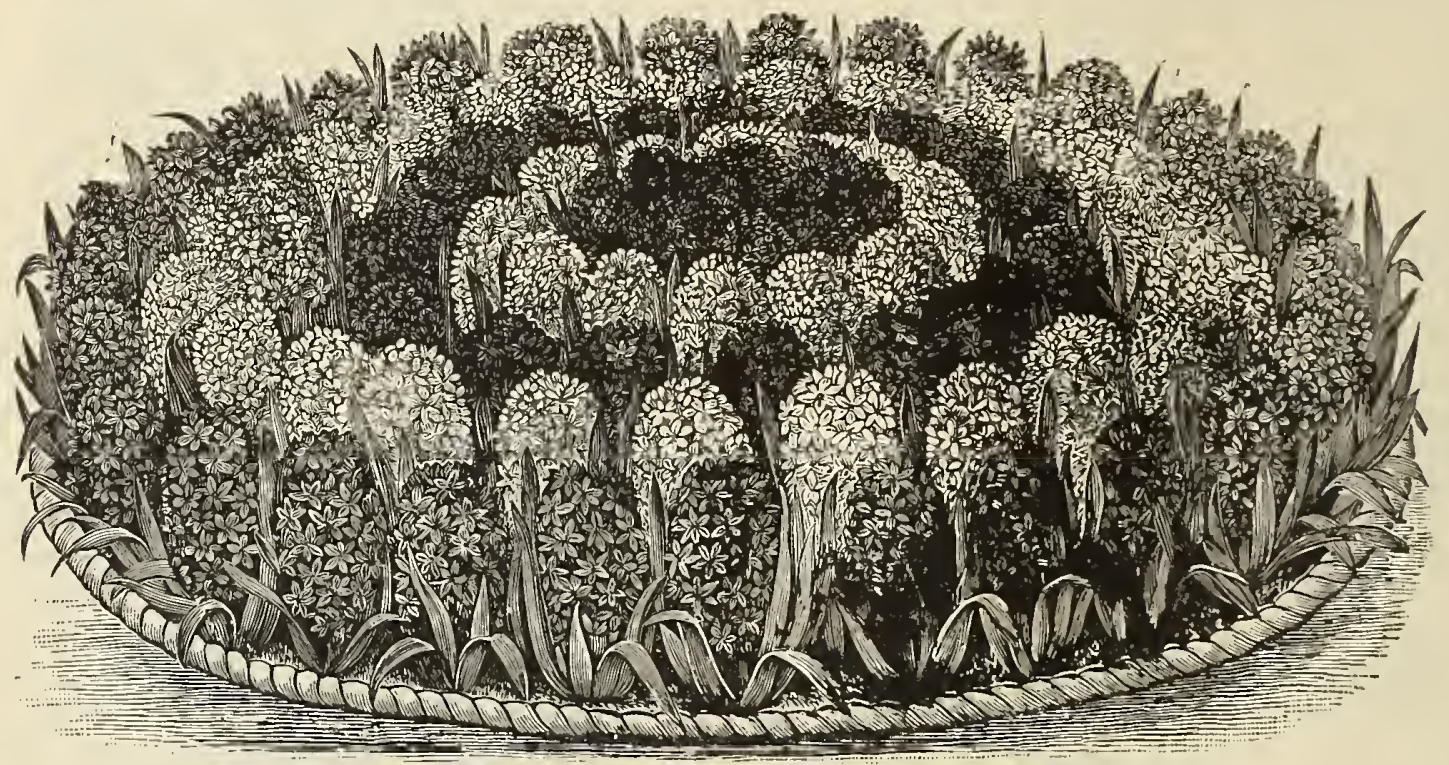

Round Bed of S. \& W. Special Bedaing Hyacinths

\section{Our S. \& W. Special Bedding and Forcing Hyacintbs.}

The bulbs under this heading are of a much larger size than those put in ordinary mixtures; in fact, most of these average as large as those often sent out as "First Size Named" by some dealers. They are of the same age as the first size fancy named Hyacinths offered by us, from which they are the second selection. They will produce grand spikes of bloom; and the different sorts, as offered below, all being of one shade of color and all blooming at one time, render them of great value for forcing or bedding out, especially in designs, enabling one to secule the exact color effect desired, which is a great advantage over mixed reds, mixed blues, etc., at but a slight advance in price.

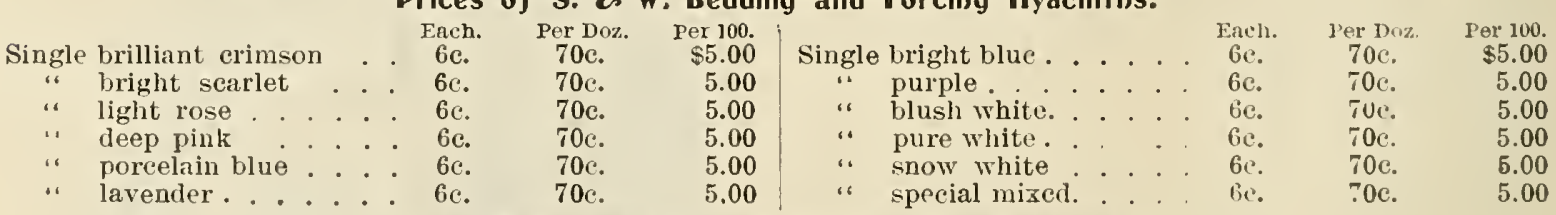

Delivered Free anywhere in the United States.

\section{Mixed Dutcb Myacinths.}

These $\mathrm{Hyacint} \mathrm{hs} \mathrm{are} \mathrm{all} \mathrm{large-sized} \mathrm{healthy} \mathrm{bulbs,} \mathrm{well} \mathrm{adapted} \mathrm{for} \mathrm{outdoor} \mathrm{planting.} \mathrm{The} \mathrm{colors} \mathrm{bring} \mathrm{kept} \mathrm{sepa}$ rate, the purchaser can make his selection of colors as his taste may dietate. The hulbs ean also be forced for wintel flowering or cutting. Bedding and forcing varieties are kept separate. Please state which to send when order ing.

\section{Single Mixed Varieties.}

Pure white, blush white, rose, l'ed, light blue, dark blue, vellow, mixed all colors. Each, 5c.; doz., 50c; 100, \$4.00.
Double Mixed Varieties.

Pure white, blush whlte, rose, red, light blne, dark blue, yellow. mixed all colors. Each, 5c.; doz , 50c. ; $100 \$ 4.00$. 


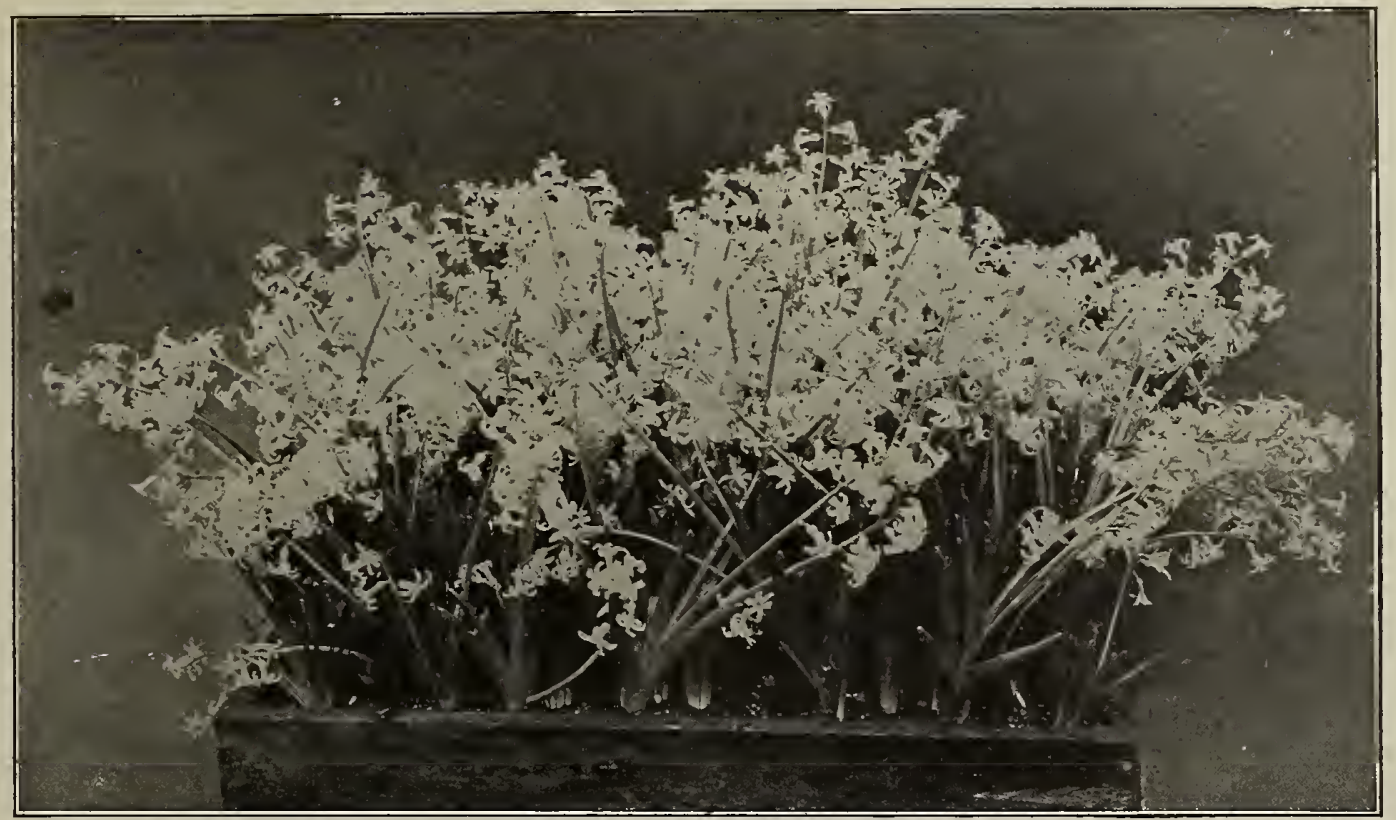

A Box of French Roman Hyacinths

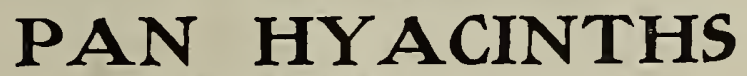

(Sometimes called Dutch Romans)

This method of growing Hyacinths for Winter flowering in the house has given the most satisfactory results. A number of florists used this method for creating something new in the line of an Easter display with the result that there was a much greater demand than supply, owing to the beautiful display the Hyacinths in pans make. The secret of acquiring success is simply the following: Plant only one kind of Hyacinth in one pan, in order to have them all bloom at once, and to have them all the same shade. The various sorts of Hyacinths invariably grow different from one another, and if planted together, the result will turn out accordingly. The following varieties of pan Hyacinths are the best known sorts for this mode of growing, and if by planting 10 to 12 bulbs of either of the twelve varieties mentioned in a pan 8 to 9 inches in diameter and following the directions of planting Hyacinths in pots, the most satisfactory results will be obtained.

In ordering bulbs for this purpose, be sure to mention Pan Hyacinths.

Gertrude, Fine pink.

Roi des Belges. Bright red.

Cardinal Weisman. Rosy carmine.

Gigantea. Pale pink.

L'Innocence. Pure white.

La Grandesse. Pure white, large spike.

Price of any of above named varieties 50c. per doz. by mail prepaid, cr 53.50 per 100 by express prepaid.

\section{Varieties and Prices}

\section{ROMAN HYACINTHS}

Make splendid plants for the window garden, grown in whatever device may be desirable. They should be treated in all respects like the other classes, only that they come into flower much earlier, and should, for first flowers, be brought in by the 15 th of November; by so doing, they will sive their flowers in perfection by Christmas.

The great beauty of this class of Hyacinths is their profusion of flowers, each bulb giving from three to six spikts, according to the size and strength of bulb. The flowers are smaller than those of the Dutch Hyacinths, but more graceful. The bulbs being small, three can be put in a 5 -inch pot.

Doz. $100 \quad 1000$

White Roman Hyacinths, Jumbo. $\$ 0.75 \quad \$ 5.50 \quad \$ 50.00$ White Roman Hyacintlis, Manumoth $\ldots \ldots \ldots \ldots \ldots \ldots \ldots$

White Roman Hyacintlis, 13 to 15 Cent. ......................

White Roman Hyacinths 12 to 15 Cent. ..................... Single Rose Roman Hyacinths, 12 to 15 Cent................

$\begin{array}{rrr}.60 & 4.50 & 40.00 \\ .50 & 4.00 & 35.00 \\ .40 & 3.50 & 30.00 \\ .40 & 3.50 & 30.00\end{array}$

Single Blue Roman Hyacintls, 12 to 15 Cent............... $\$ 0.40 \$ 3.50 \$ 30.00$ Single Yellow Roman Hyacintlis, 12 to 15 Cent................ .75 $5.00 \quad 45.00$

Double Rose Roman Hyacinths, 12 to 15 Cent............... .50 3.75 32.50

White Italian Roman Hyacintlıs, 12 to 15 Cent...............4 .40 3.50 30.00 


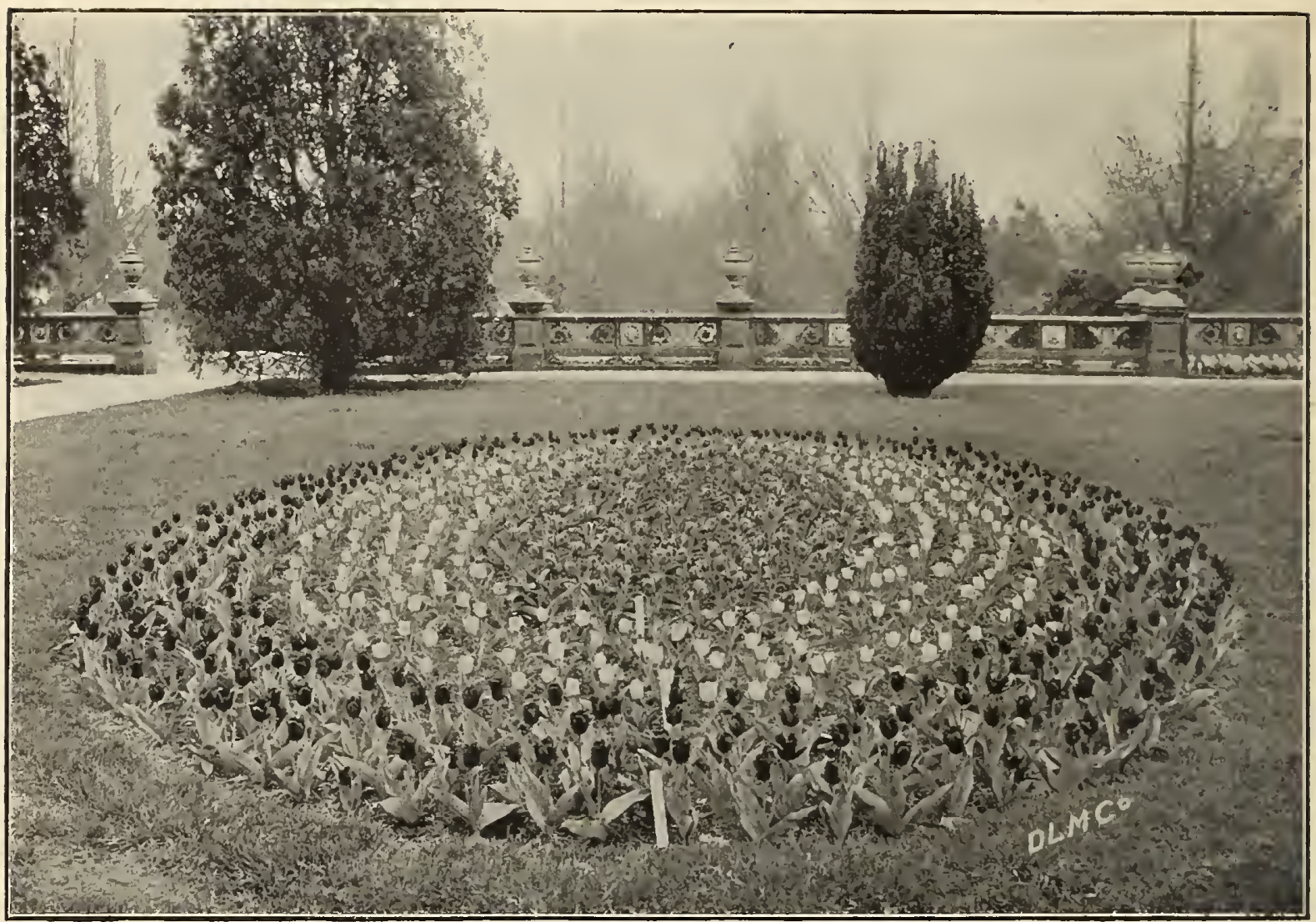

\section{Bed of Single Early Tulips \\ SINGLE EARLY TULIPS}

Tulips are sueh universal favolites that it is scarcely necessary to dwell upon their merits here. Their ease of culture, combined with beauty of form and gorgeous eoloring, renders them the most popular bulbs grown for Spring bedding, and for Winter flowering in the greenhouse and rindow garden they are ineomparable. The Tulip is perfectly hardy and of easy eulture, flowering as freely in the shade as in the sunshine, and producing as fine flowers in a confined town garden as in a more favored plaee. Double and Single Tulips, when associated together and planted in front of shrubs, maintain a longer display than if either is separately planted. In gardens where the flower beds are to be kept gay from the earliest day of spring, plant between the lines of Tulips, Seilla Sibiriea, Chionodoxas, Snowdrops or Croeus, as these flower first and are through when the Tulips come into bloom.

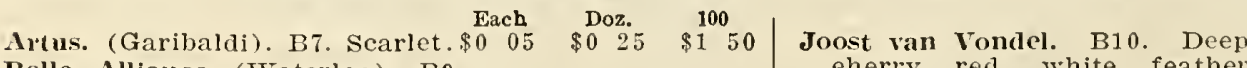

Fach Doz. 100

Belle Alliance (Waterloo). B9

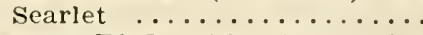

Canary Bird. As. Pure rich golden yellow. Excellent for forcing or bedding.........

$05 \quad 50 \quad 300$

Cardinal's Hat. B9. Dark brownish red, very showy...

Chrysolora. B9. Pure yellow.

Cotlage Maid. B9. White, edged

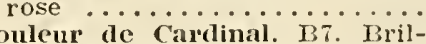

liant crimson ............

Cramoisi I3rilliant. C9. Brilliant scallet flower; fine for bedding or forcing .......

Crimson Íing. C9. Large, bright crimson flowers, with yellow base; a popular bedder...

Ducluesse de Parma. B8. Red, yellow border

Flamiıgo. Beautiful dark pink

Ilobbema. Salmon pink...... $\begin{array}{lll}60 & 3 & 50\end{array}$ eherry red, white feather

through center of petals

pretty $\ldots \ldots \ldots \ldots \ldots \ldots \ldots \ldots \$ 0 \quad 05 \$ 0 \quad 30 \$ 200$

Joost van Vondel. White.... son, with broad orange yellow margin, large and exeeedingly effective Yellows. B. Grand rich rellow lare, fine flowers

La Reine (Queen Vietoria). BS. White faintly tinted rose, good for bedding and foreing....

I'Immaculee. B9. Pure White, yellow base, large, broad petaled flower; very early and fine ............ Grand rich. vellow, extra large, fine flower

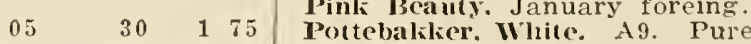
1501000 white, fine large and showy

$\begin{array}{llll}05 & 30 & 2 & 00 \\ 05 & 50 & 3 & 00 \\ 05 & 25 & 1 & 75 \\ & & & \\ 05 & 20 & 1 & 50 \\ 05 & 50 & 3 & 50 \\ 05 & 50 & 4 & 50 \\ 05 & 35 & 2 & 50\end{array}$
out of bloom, etc. The figures Indicate average helght In laches. All the above prices Include dellvery anywhere in the U. S. 
Pottebakker, Scarlct. Bright Eac dazzling scarlet; very large.

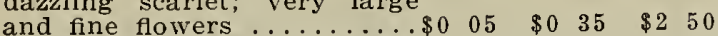

Pottebakker, Yellow. A9. Large, fine, bright yellow, feathered

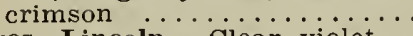

Pres. Lincoln. Clear violet...

Prince of Austria. Fine orange

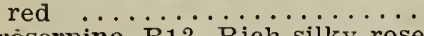

Próserpine. B12. Rich silky rose

Queen of the Netherlands. Delicate pink .....................

Rachel Ruisch. rose, shaded white, fine for forcing, beautiful ....... mine, pink, feathered white, through center of petals, white base, large flower....

Rose Grisdelin. C7. Delicate rose shaded blush white; fine for bedding or forcing.......

Rose Luisante. C8. Dark rose, extra fine Bio. Orange, effective, large, sweet-scented.

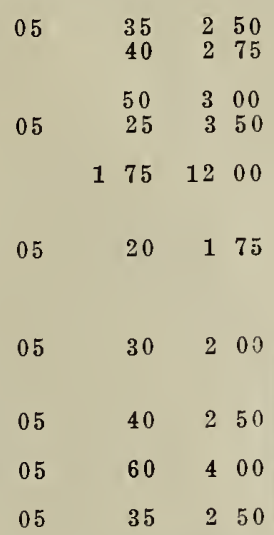

Veruuilion Brilliant. B5. Deep, Each dazzling vermilion, magnificent; extra fine for pots and massing ............. \$0 $05 \quad \$ 0 \quad 50 \quad \$ 3 \quad 50$

White Hawk, January forcing. $05 \quad 50 \quad 4 \quad 50$

White Swan. C9. Large pure white; extra fine for bedding

Tellow Prince. B9. Bright yellow, large and showy, the finest low-priced yellow tulip for bedding out........ $.05 \quad 35 \quad 225$ Single Wlute $\ldots \ldots \ldots \ldots \ldots \ldots \ldots 0 \quad 20 \quad \$ 1 \quad 00 \quad \$ 900$

Single Pink ........... $25 \quad 125 \quad 1000$

Single Red............. $30 \quad 150 \quad 1250$

Single Yellow ............ $25 \quad 1 \quad 25 \quad 10 \quad 00$

Single Red and Yellow ...... $25 \quad 2 \quad 125 \quad 10 \quad 00$

Single Extra Fine Mixed. From 25 named varieties ....... $30 \quad 150 \quad 12 \quad 50$

Duc van Tliol. Red and yellow...... $\$ 0^{2} \quad 20 \quad \$ 1 \quad 25$

Duc van Thol. Scarlet ........... $25 \quad 175$

Duc valt Thol. White ............ $30 \quad 2 \quad 25$

Duc van Thol. Yellow........... $40 \quad 250$

\section{DOUBLE TULIPS}

Double Tulips have massive flowers of brilliant and varied colors, shades and markings, and being double, the flowers last much longer in bloom than single varieties, and in consequence, when singles and doubles are planted in conjunction, the

"time of the Tulips" is greatly prolonged. Double Tulips are beautifully adapted for beds on the lawn, in the garden, and for mingling in clumps of half a dozen or more around the edges of shrubbery. Are robust growers and exceedingly effective.

Agnes. Vermilion. Doz. $25 \mathrm{c} ., 100 \$ 1.50$.

Blanche Hative. A10. Very fine, large, semi-double, pure white, very early. Ea. $10 \mathrm{c}$, doz. $60 \mathrm{c} ., 100 \$ 4.00$.

Couronne d'Or. B10. Large flower, very double, rich golden-yellow, shaded orange. Ea. 8c., doz. 60c., $100 \$ 4.00$.

Count Leicester. B7. Orange and yellow, feathered Ea. $5 \mathrm{c}$, doz. $35 \mathrm{c} ., 100 \$ 2.50$.

Duke of York Carmine, red and yellow. Doz. 35 c., $100 \$ 2.00$.

Gloria Solis. Red bordered with gold. Doz. $35 \mathrm{c} ., 100 \$ 2.00$.

Imperator Rubrorum. A9. Splendid bright scarlet, yellow base; a fine full double. Ea. 5 c., doz. 50 c., $100 \$ 3.00$.

La Candeur. B8. Pure white, very full and large, extensively grown for bedding. $\mathrm{Ea} .5 \mathrm{c} .$, doz. $35 \mathrm{c} ., 100 \$ 1.75$.

Le Blason. A9. A beautiful variety of delicate rose, shaded and striped with white, extra fine. Ea. 5c., doz. $50 \mathrm{c}$., $100 \$ 2.75$.

Murillo. B8. Magnificent blush-white, shaded rose, large flowers, fine for forcing. Ea. 5c., doz. $40 \mathrm{c}$., $100 \$ 3.00$.

Rex Rubrorum. B9. Bright crimson-scarlet, superb for bedding, large and showy. Ea. $5 \mathrm{c}$, doz. $35 \mathrm{c}$., $100 \$ 2.50$.

Rose Blanche. Pure white. Doz. 30c., 100 $\$ 1.75$.

Salvator Rosa. A7. Beautiful deep rose, flamed with white, fine for forcing. Ea. $10 \mathrm{c}$., doz. $50 \mathrm{c}$., $100 \$ 4.00$.

Toreador. Ried with rich yellow border. Doz. $\$ 1.00$, $100 \$ 7.00$.

Tournesol. A9. Splendid showy tulip orange scarlet, with broad yellow tips and yellow base. Very large double flower. Ea. 5c., doz. $35 \mathrm{c}$., $100 \$ 2.75$.

Tournesol Yellow. A9. Bright golden yellow, shaded orange. Very fine large and showy flower; forces well. Ea. 10c., doz. $80 \mathrm{c} ., 100 \$ 4.50$.

Superfine Mixed. Doz. $25 \mathrm{c} ., 100 \$ 1.00$.

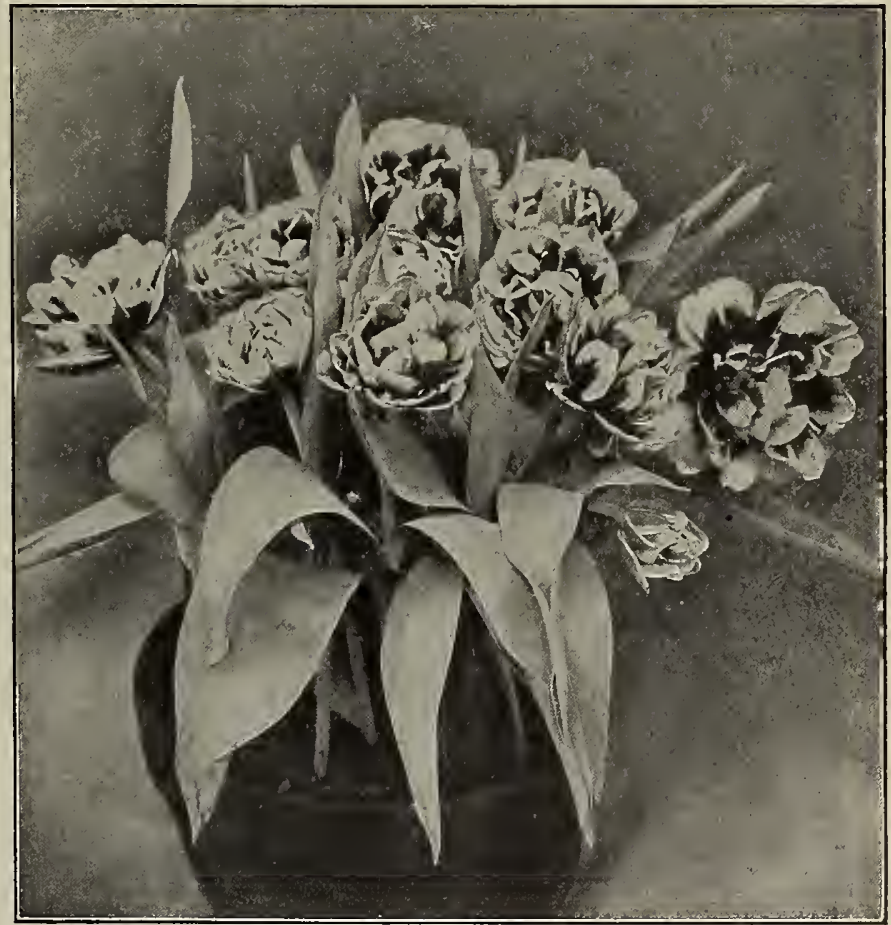

Double Tulip

Double Paeony Flowered Tulips

The very largest and best flowering of the double varieties, producing flowers of enormous size, often measuring $5 \frac{1}{2}$ to 6 inches in diameter.

Double Preony flowered scarlet... \begin{tabular}{ccccccc} 
Each & \multicolumn{1}{c}{ Doz. } & 100 & $\$ 1$ & 00 & $\$ 5$ & 00
\end{tabular} Double Preony flowered white.... $\quad \begin{array}{llllll}\mathbf{1} & \mathbf{1} & 0 & 0 & \mathbf{5} & 0\end{array}$ Double Preony flowered yellow... $\quad \begin{array}{lllllll}10 & \mathbf{1} & 0 & 0 & \mathbf{5} & 0 & 0\end{array}$

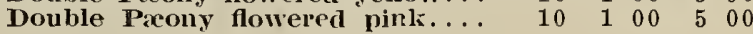




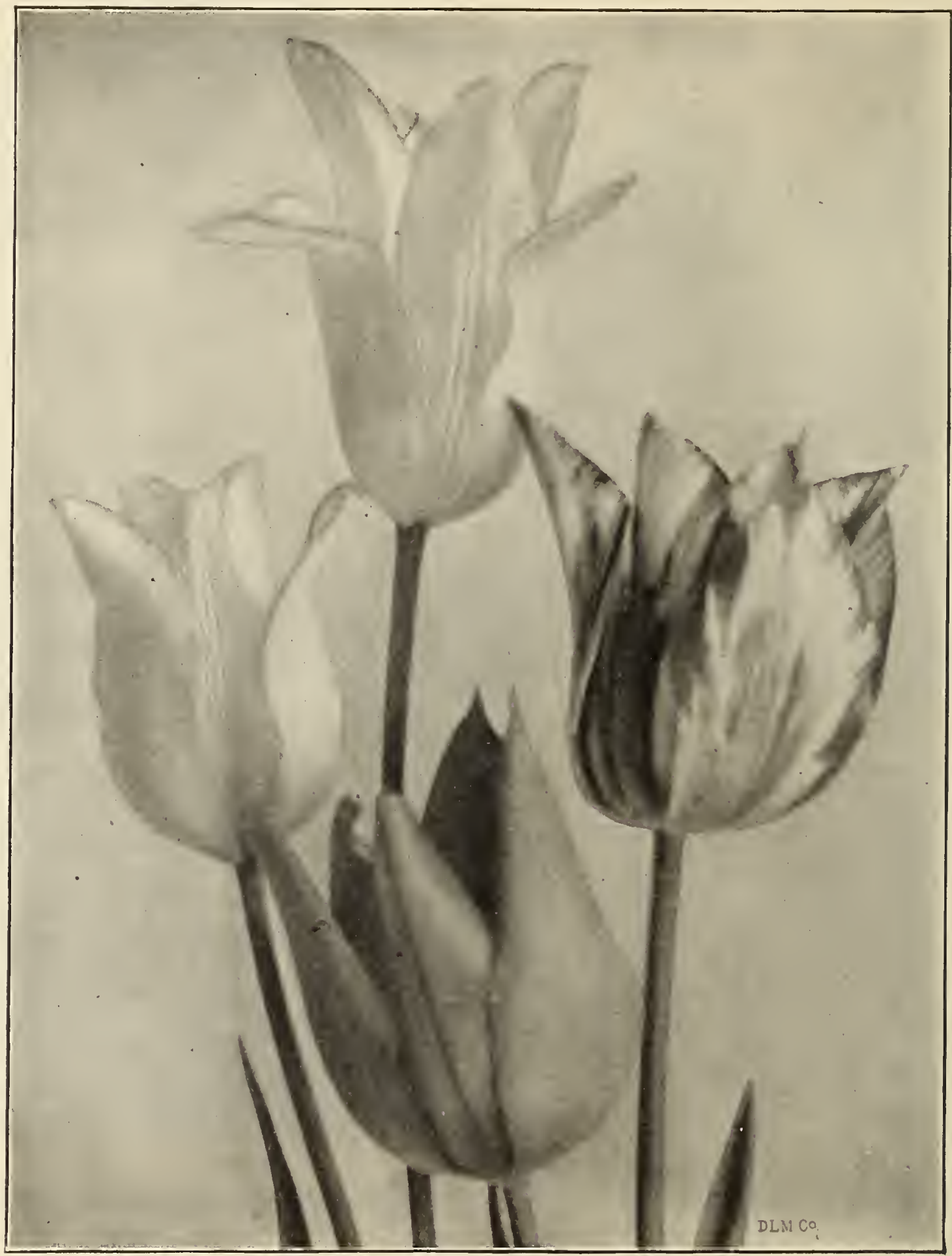

Late Flowering Tulips. Four Fine Varieties-Elegans Alba, Picotee, Union Jack, Isabella (See page 9) 


\section{LATE FLOWERING TULIPS}

This group of Late-Flowering Garden Tulips generally is in full flush of bloom about "Decoration Day." "They differ from the Early Single Tulips by their taller growth and later bloom. They are brilliant in the extreme for bedding purposes. The flowers are very large, symmetrically formed and their magnificent colors, with interesting and delicate featherings and markings, make a sight not soon to be forgotten, particularly when bedded out in quantity. They are very hardy and do well through all sorts of weather.

\section{SINGLE LATE COTTAGE OR OLD ENGLISH TULIPS}

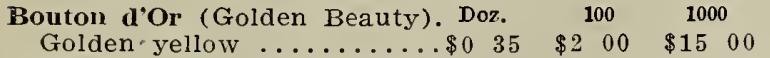

Bridesmaid (Maid of Holland). Violet red striped.........

Caledonia. Bright orange red

Elegans Alba (White Crown). Large, white reflexed petals margined rosy red. A very attractive flower ........

Fulgens Maxima Lutea (Mrs. Moon). Yellow; the largest of all late Tulips........ $1000 \quad 6 \quad 00 \quad 5500$

Gesneriana Aurantiaca Maculata (Orange Beauty). Brilliant orange red; enormous

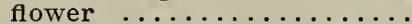

Gesneriana Spathulata ( $\mathrm{Ma}-$ jor). Brilliant scarlet; blue center. One of the best in

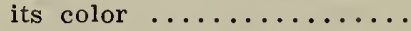

Golden Crown. Yellow, bright yellow bordered and feath-

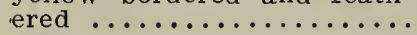

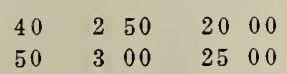

60

400

$35 \quad 00$

50

300

2500

$40 \quad 2 \quad 50 \quad 20 \quad 00$

$25 \quad 1 \quad 50 \quad 10 \quad 00$
Inglescombe Pink (Salmon Doz. 100

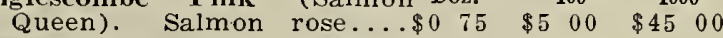

Isabella (Shandon BelisBlushing Bride). Carmine rose, creamy white shaded; splendid forcer. One of the most useful of all late tulips

La Merveille. Brilliant orange red and carmine. One of the largest and best in its

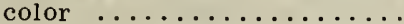

Picotce (Maiden's Blush). White, margined rose. One of the most popular varie-

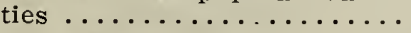

Uuion Jack (Distinction). Lilac and white striped; very conspicuous .............

Superfine Late Mixed........ Bizards Mixed . . . . . . . .

Breeders Mixed $\ldots \ldots \ldots \ldots$.

Byblooms Roses $\ldots \ldots \ldots \ldots \ldots$

$40 \quad 250$

2000

Byblooms Violets $\ldots \ldots \ldots \ldots$

\section{DARWIN TULIPS}

Darwin Tulips belong to the late or May-flowering section, and ar: destined to be extensively grown for bedding or massing purposes. The flowers are very large, of symmetrical form, and are borne on tall strong stems, often two feet high. They $b_{y}$ far surpass in colors aric brilliancy anything before known in Tulips. The include almost every corceivable colur and shade, ferm the daintiest blue to the darkest violet, from soft rose to the most brilliant red, and from light brown io what is believed to be the darkest black in the floral world.

Clara Butt. Delicate salmon Ioz. $100 \quad 1000$ pink. A very beautiful and attractive flower ......... $\$ 0 \quad 60 \quad \$ 5 \quad 00 \quad \$ 45 \quad 00$

Early Dawn ........... $50 \quad 4 \quad 00 \quad 3500$

Europe. Brilliant scarlet carmine .................

Gretchen (Margaret). Delicate flesh color. A very lovely fiower ................

La Candeur (White Queen). Almost pure white.......

$\begin{array}{lllllll}50 & 4 & 00 & 35 & 00 \\ 50 & 4 & 00 & & 35 & 00 \\ 50 & 4 & 00 & 35 & 00\end{array}$
Madame Krelage. Vivid pink, Doz. $100 \quad 1000$ light bordered .........\$0 $50 \quad \$ 400 \quad \$ 3500$
i'ride of Haarlem. Same color as Proserpine; enormous
flower ..................... $60 \quad 500 \quad 4500$ Sultan (Joseph Israels). Black $40 \quad 300 \quad 2500$ Psyche. Delicate pink; very beautiful ............... $100 \quad 700 \quad 6500$

Glory. Brilliant scarlet .... $40 \quad 300 \quad 2500$ Vedding Veil. White with lilac shade ............ $40 \quad 3 \quad 00 \quad 2500$

Fine Mixed .............. $30 \quad 200 \quad 1600$

\section{PARROT TULIPS \\ THREE-YEAR-OLD FLOWERING BULBS}

These Tulips belong to the late-flowering garden varieties, which are generally in full bloom during the latter part of May. The Parrot Tulips have immense picturesque forms and brilliant showy colors. The petals have peculiarly feathered and fringed edges, and the shape of the flower, especially before it opens, resembles the neck of a parrot. They form extravagantly showy beds, an unlimited variety of colors making a very effective display in the flower garden.

Admiral de Constantinople. Large red flowers, tipped Markgraaf van Badcn. Yellow, striped with scarlet with orange.

Cramoisi Brilliant. Deep carmine, very handsome.

Lutca Major. Large bright yelłow.

Gloriosa. Very large yellow flowers, with red stripes. and green.

Perfecta. Yellow and rad striped.

Price, 75c. per doz., \$5.00 per 100.

A collection of one of each of the above named six sorts for 50c., postpaid. Mixed Parrot Tulips, per doz.. 40c.; per 100, $\$ 3.00$. 


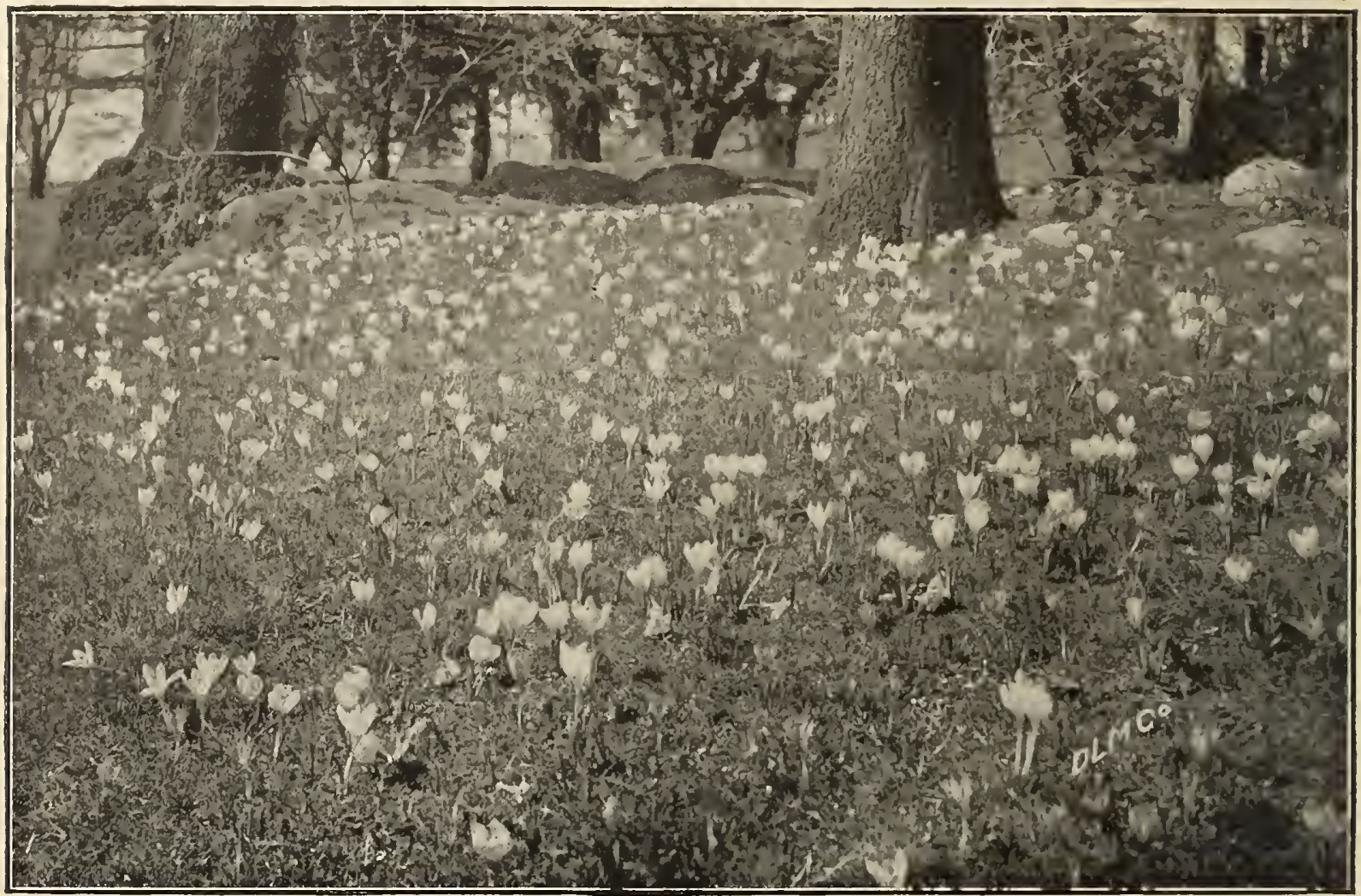

\section{CROCUS}

The Crocus is one of the earliest flowers of Spring, and occupies a prominent place in erery garden. When planted as an edging, in triple lines of one or more colors, the effect is striking. Spring display surpasses that of Crocus; the broad wavy bands of golden yellow, striped, purple, or of pure white, when they expand their blossoms in February and March, are incomparable. In lawns and pleasure parks, planted in the grass, the Crocus is extremely effective. They are easily planted indiscriminately in the turf with the aid of a dibber-after Fall rains have made the soil moist. The flowers and foliage are gone before the lawn needs mowing, so they do not interfere with the Summer beauty of the lawn. For several years past Crocus, Snowdrops, Daffodils, etc., have been planted in our parlis and lawns, in wild places, woodland walks. etc., to the great delight of visitors and enhanced decoration of the parks. In one of the parks thousands of Crocus were used in the grass, and the effect was matchless. If ordered by mail, add 25 cents per 100 for postage. Larger lots sent by express, buyer paying transit.

\section{Mixed Crocus}

Hunc, White, Purple and Yellow. Per doz. 10c., per 100 50c., per $1000 \$ 4.00$.

Striped. Per doz. 10c., per $10050 \mathrm{c}$. , per $1000 \$ 4.00$. IIl color's mixed. Per doz. 10c., per $10040 \mathrm{c}$., per $1000 \$ 3.50$.

\section{Named Large Flowering Crocus}

Baron von Brino. Purplish blue. Per doz. 20c., per $100 \$ 1.00$, per $1000 \$ 7.50$.

Conroline Clisholm. Fine white. Per doz. 20c., per $100 \$ 1.00$, per $1000 \$ 7.50$.

Cloth of Gold. Golden striped brown. Per doz. $20 \mathrm{c}$., per $100 \$ 1.00$, per $1000 \$ 7.50$.

Cloth of Silver. White striped lilac. Per dloz. 20c., per $100 \$ 1.00$, per $1000 \$ 7.50$.

\section{Autumn Flowering Crocus (Colchicum)}

Colchicum Autummale. Very effective and handsome, hardy plants, the flowers of which come through the ground without leaves in the Fall, the leaves appearing the following Spring. These bulbs can also be grown in the Fall of the year in shallow bowls of water, or in pots of earth, when they will come into bloom in two weeks after planting, making a very pretty display at a time when blooming plants are very scarce. The flowers comprise many shades of white, purple, rose and striped.

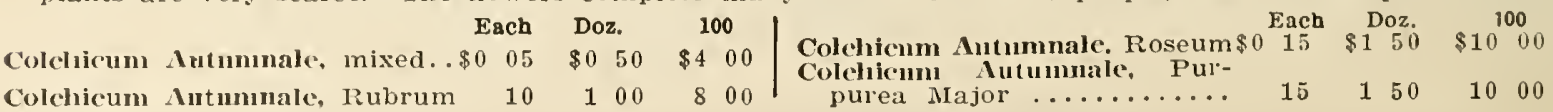

King of the Blues. Large blue. Per doz. $20 \mathrm{c}$, per $\$ 1.00$, per $1000 \$ 7.50$

Madam Mina. Striped purple and white. Per doz. $20 \mathrm{c}$. per $100 \$ 1.00$, per $1000 \$ 7.50$.

Purpurca Grandiflora. Purple. Per doz. 20c., per Iout $\$ 1.00$, per $1000 \$ 7.50$

Queen of the Whites. Pure white. Per doz. $20 \mathrm{c}$. per $100 \$ 1.00$, per 1000 blue and white, Per doz. $20 \mathrm{c}$., per $100 \$ 1.00$, per $1000 \$ 7.50$.

ellow Mammoth. Per doz. $20 \mathrm{c}$, per $100 \$ 1.00$, pel $1000 \$ 7.50$.

Cllow Jumbo 13nlbs. Per doz. 25c., per $100 \$ 1.50$. per $1000 \$ 12.50$. $\$ 1.00$, per $1000 \$ 7.50$ 


\section{NARCISSUS OR DAFFODILS}

In this genus we have a long list of established favorites, remarkable for their fragrance and precocity of their flowers. They are all hardy, with the exception of Bulbocodium and the Polyanthus varieties. Give them the same treatment as Hyacinths for outdoor cultivation.

LARGE AND MEDICM TRUMPET VARIETIES. If ordered by mail, add 12 cents per dozen for postage.

IRISH KING. Rich yellow trumpet, very early. Ea. 5c., doz. 50c., $100 \$ 3.00$.

BARRI CONSPICUUS. The finest of this class, longstemmed flowers with beautiful broad petaled perianth $3 \frac{1}{2}$ inches across, sparkling canary yellow with deep golden cup richly edged with orange scarlet; awarded a first-class certificate. Ea. 4c., per doz. 40c., per $100 \$ 3.00$.

CYNOSURE. Large across, light yellow, with rich, deep yellow broad cup; a great beauty, and one of the best for either forcing or open grounc planting. Ea. 5c., per doz. 30c., per $100 \$ 2.00$.

EMPRESS. A magnificent, large variety, bold and erect. A rare beauty. Some give this the claim of being the best of the two-colored Trumpets. Perianth white and of great substance, trumpet rich yellow.

\begin{tabular}{|c|c|c|c|c|}
\hline & Each & Doz & & 100 \\
\hline umbo Bul &.$\$ 01$ & $\$ 1$ & & $\$ 500$ \\
\hline Loth Bulb & 0 & & 50 & 3 \\
\hline
\end{tabular}

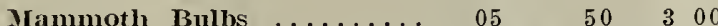

EMPEROR. One of the finest Daffodils in cultivation; entire flower of the richest yellow, trumpet of immense size, and the petals of the perianth are so broad that they overlay and measure $3 \frac{1}{2}$ inches across. Grand for cutting.

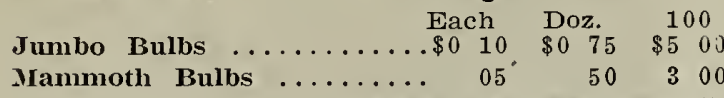

GOLDEN SPUR. One of the grandest Daffodils, with extra large, bold, rich yellow flowers, foliage very broad and striking. It is of unusually robust habit and unsurpassed for gardens, pots or forcing. Early and extremely free flowering.

Doz. 100 Jumbo Bulbs $\ldots \ldots \ldots \ldots \ldots \ldots \ldots \ldots \$ 0 \quad 75 \quad \$ 500$ Mammoth Bulbs ........... $50 \quad 300$ First Size $\ldots \ldots \ldots \ldots \ldots \ldots \ldots \ldots \ldots$ 35 200

HORSEFIELDI. The Queen of the Daffodils, Very large flowers of pure white, with rich yellow trumpet. Very stately and beautiful, and one of the most elegant for ladies' corsage wear. The flowers are the largest of this class, very early and freeblooming, a grand cut flower; and eagerly sought after as one of the finest.

Bulbs Each Doz. 100 .

... $05 \quad 30 \quad 150$

LEEDSI. Circe. Fine pure white, cup slightly tinted with light straw but changes to white. A very distinct and pretty variety. Per doz. 25c., per 100 $\$ 1.50$.

MAXIMUS OR HALE'S BEATEN GOLD. One of the largest and most beautiful of this class. Very large flower, of rich, deep golden yellow. Remarkable for an elegantly twisted perianth. Trumpet deep golden, large, well flanged and deeply fluted. The darkest and richest yellow of all Daffodils. Ea. 8c., per doz. 75 c., per $100 \$ 5.00$.

MME. DE.GRAAFF. One of the largest and finest of all white trumpet Daffodils, perianth pure whitc, trumpet very pale primrose, passing off pure white, a most refined and delicate flower. Strong healthy grower; 1st Class Certificate London $R$ H. S., Floral Certificate Daff Conference 1896. Figured Gardener's Chronicle 18 April, 1896. Ea. 30 c., per doz. $\$ 3.00$, per $100 \$ 20.00$.

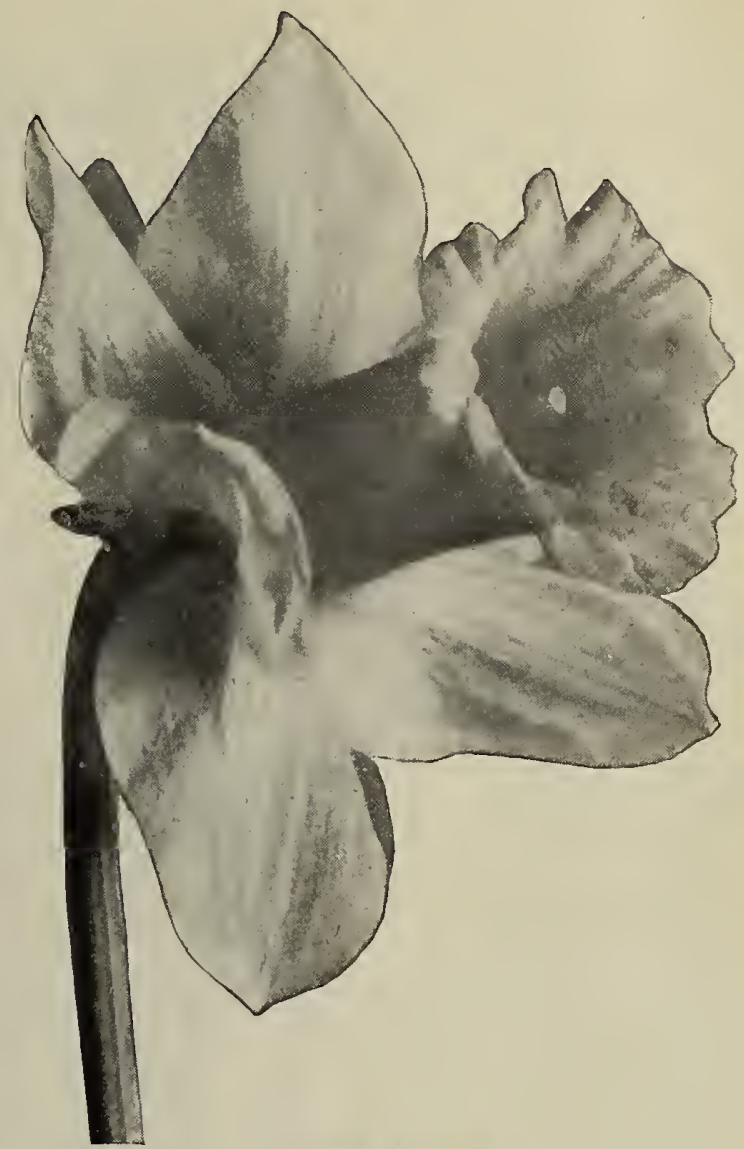

Narcissus Empress

PRINCEPS. Very early. This is one of the most popular winter-flowering and forcing varieties grown. Flowers large, perianth sulphur, an immense rich yellow trumpet. Ea. $5 \mathrm{c}$., per doz. $30 \mathrm{c}$., per $100 \$ 2.00$.

SIR WWTKIN. "The Giant Chalice Flower," or "Big Welshman." A gigantic variety, immense longstemmed flowers, sometimes measuring $5.1 / 2 \cdot$ inches across, being the largest variety grown. Color a rich light yellow, with a very large dark cup, tinted with orange. Ea. $8 \mathrm{c}$., per doz. $70 \mathrm{c}$, per 100 $\$ 2.50$.

STELLA. One of the first in flower and wonderfully free-blooming. White star-shaped flowers, 3 inches across with bright yellow cups, very beautiful, and one of the most popular forcing and cutting varieties for the London flower market. Ea. 3c., per doz. $25 \mathrm{c}$., per $100 \$ 1.50$.

TRUMPET MAJOR. Flower large and almost of a uniform deep golden. Highly prized as an early forcing sort and largely planted for outside bedding. Ea. 5c., per doz. $30 \mathrm{c}$., per $100 \$ 1.75$.

VICTORIA. New; a bi-color famous for its large and durable flowers, which stand boldly erect; broad perianth of creamy white; large, broad, fluted trumpet of rich yellow; a strong grower with massive flowers. Ea. 10c., per doz. $75 \mathrm{c}$., per $100 \$ 4.50$.

MIXED LARGE TRUMPET NARCISSUS. Plant liberally of these for cutting purposes and naturalizing. Per doz. $30 \mathrm{c}$., per $100 \$ 1.50$, per $1000 \$ 10.00$. 


\section{THE CHINESE SACRED OR ORIENTAL NARCISSUS}

The "Shui Sin Far," or Water Fairy Flower, or Flower of the Gods, as it is called by the Celestials, is a variety of Narcissus bearing in lavish profusion chaste flowers of silvery white, with golden yellow cups. They are of exquisite beauty and entrancing perfume. The bulbs are grown by a method known only to themselves, whereby they attain great size and vitality, ensuring I uxuriant growth and immense spikes of florvers. They do well in pots of earth, but are more novel and beautiful grown in shallow bowis of water with enough of fancy pebbles to prevent them from toppling over when in bloom. A dozen bulbs started at intervals will give a succession of. flowers throughout the Winter. Price, buyer paying transit, $10 \mathrm{c}$. ea., $\$ 1.00$ per doz., $\$ 7.50$ per 100 .

Mammoth Bulbs, bearing twice the number of flowering stems as the regular size, $15 \mathrm{c}$. ea. $\$ 1.50$ per doz.

\section{Narcissus Paper White Grandiflora}

A decided improvement over the ordinary Polyanthus Paper White Narcissus, producing a vigorous growth and a very large truss, bearing beautiful clusters of large, pure white flowers. This variety of Narcissus is grown in the southern part of France, and generally arrives here about August 15th or September 1st, and if planted about that date, they can be brought into bloom as early as Thanksgiving Day, and when several bulbs are planted together will keep in bloom longer than a month, providing they are kept in a cool place. Give the bulbs the same treatment as you would any other Narcissus for indoor culture, except when grown in shallow dishes as described below:

\section{How to Grow Narcissus Paper White Grandi- flora in Water \\ A very unique, simple and novel} way to grow this variety of Narcissus is to place six or eight bulbs in a shallow glass or China bowl with water. Support the bulbs with pebbles or gravel as you would the Chinese Sacred Lily bulbs and you will have a beautiful and luxuriant display of elegantly perfumed flowers in a comparatively short time; in fact, inside of six weeks. after planting if desired. After the plants have been set, place the bowls in a dark place until the roots have started, when you should bring them to the light Keep the bowls filled with water and the bulbs will take care of themselves.

Price 5e, ca., 10e. per doz., \$2.00 uer 100.

Jumbo Bulbs 10c. cá., 75c. per doz., \$3.50 per 100 .

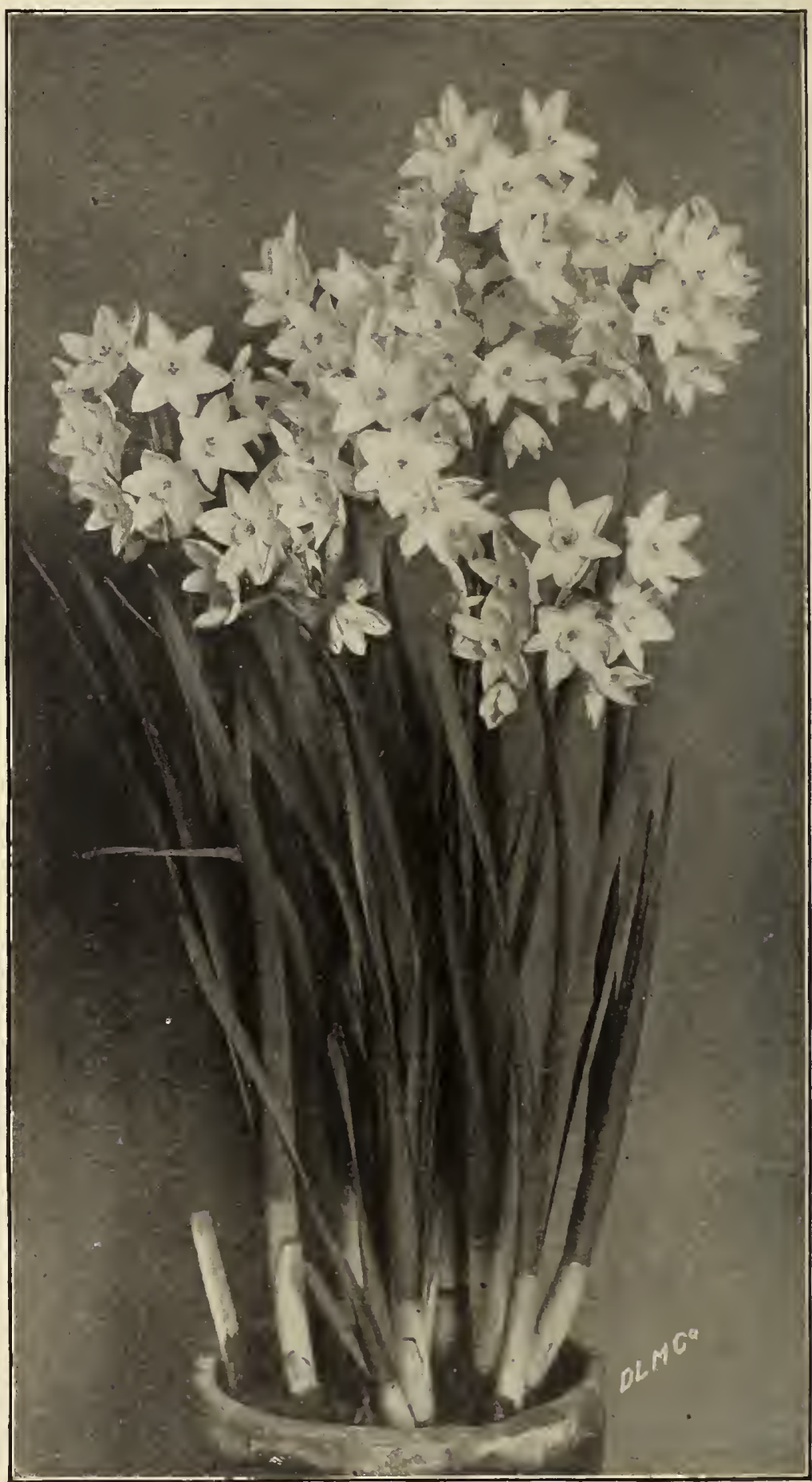

Narcissus Paper White Grandiflora

Can be grown in soil in pots or in pebbles and water. One of the most satisfactory for House Culture 


\section{DOUBLE NARCISSUS and DAFFODILS}

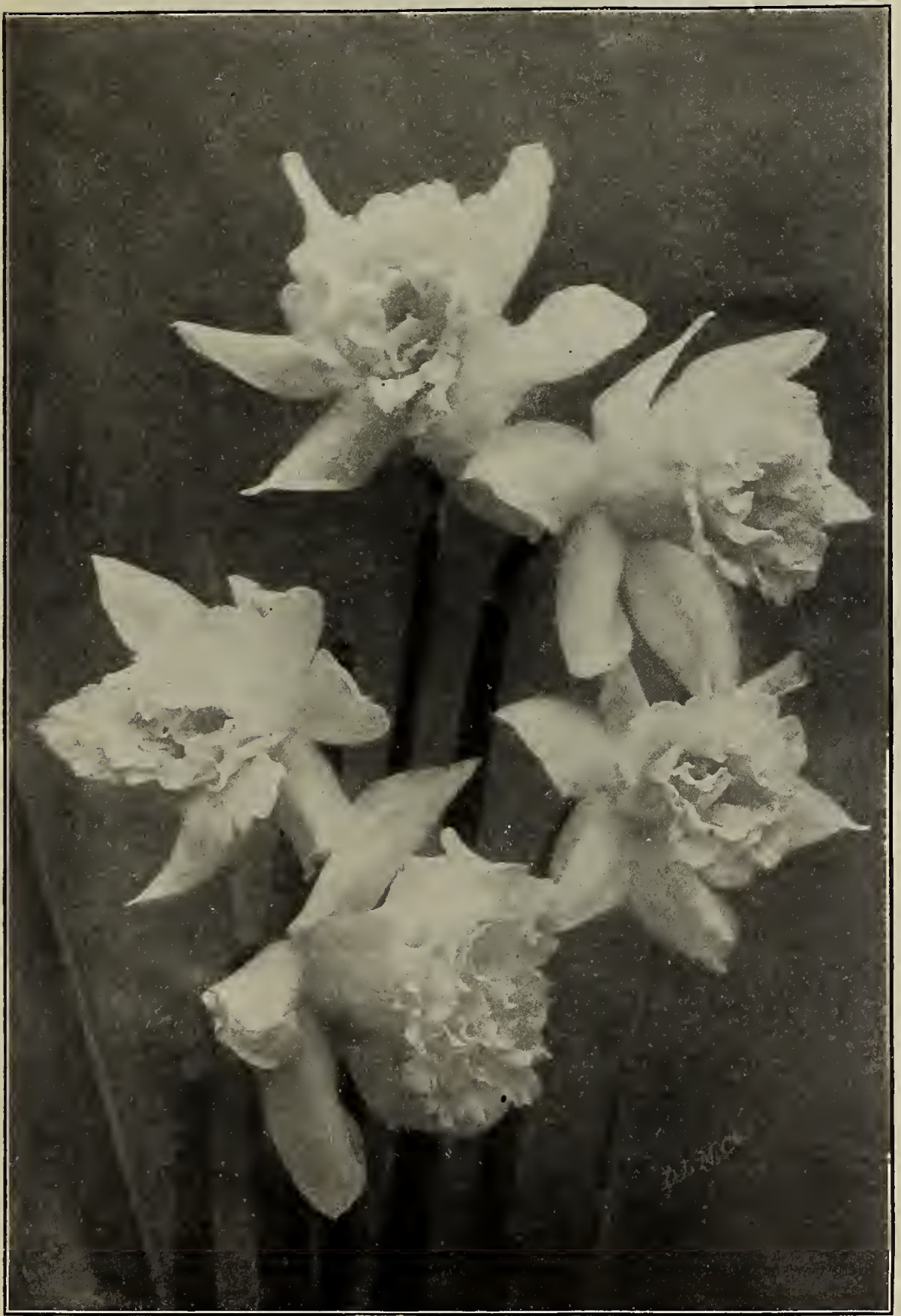

Narcissus Von Sion
Double flowering Daffodils are hardy and especially adapted for openground planting where under congenial conditions they thrive and increase for years. The early sorts are also useful for pot culture and winter forcing.

VON SION (Telamonius Plenus). The famous "Old Double Yellow Daffodil." Rich golden yellow perianth and trumpet. One of the best forcing sorts, immense quantities being grown for this purpose in Europe and America. Ea. 5c., per doz. 30c., per $100 \$ 2.00$, per 1000 $\$ 18.00$.

"DOUBLE NOSE" VON SION. Extra large bulbs, capable of producing two and three flowers each. Ea. 7c., per doz. $60 \mathrm{c}$, per $100 \$ 4.00$.

ALBA PLENA ODORATA. "The Double W"hite Poet's Narcissus or Gardenia-flowered Daffodil." Double snow-white Gardenia-like flowers, exquisitely scented. Ea. $5 \mathrm{c}$, per doz. $25 \mathrm{c}$, per $100 \$ 1.50$.

INCOMPARABLE, fl. pl. "Butter and Eggs." Full double flowers of rich yellow, with orange nectary. Splendid variety for either forcing for Winter cut flowers or for open ground planting. Ea. 5c., per doz. 20 c., per $100 \$ 1.25$.

ORANGE PHCENT. "Eggs and Bacon." Beautiful double white flowers, with orange nectary. Splendid for pot culture and cutting or garden decoration. Ea. 5c., per doz. $40 \mathrm{c}$., per $100 \$ 3.00$.

SULPHUR (OR SILVER) PHCENIX. "Codlins and Cream." Large creany white flowers, sulphur nectary. Exquisite corsage fiower, nine for growing in pots. Ea. 10c., per doz. 75c., per $100 \$ 4.00$.

MIXED DOUBLE NARCISSUS. Plant liberally of these for cutting purposes or for naturalizing. Ea. 5c., per doz. 25 c., per $100 \$ 1.25$.

\section{MIXED NARCISSUS and DAFFODILS For Naturalizing}

We offer these at exceptionally low prices to encourage liberal plantings. They are very suitable for growing in masses for garden decoration, and are grand for cutting, and are particularly adapted for mixed borders, "naturalizing" in shrubbery by woodland walks, in woods by streams and lakes and semiwild, outlying grounds. They are perfectly hardy and will flourish and increase for years.

Mixed Double and Single. Doz. 25c., per $100 \$ 1.50$, per $1000 \$ 12.00$. 


\section{POET'S NARCISSUS}

Miniature Saucer-Shaped Cups

Pocticils (Pheasant's Eye). Pure white flowers with orange cup. Per doz. $15 \mathrm{c}$., per $10075 \mathrm{c}$., per $1000 \$ 6.00$.

Poeticus Oruatus. Improved "Poeticus." Grand flower for cutting. Larger and more symmetrical than the old variety and considerably earlier. Pure white flowers, saffron cup, tinged rosy scarlet. Magnificent cut flower. Ea. 5c., per doz. $25 \mathrm{c}$, per $100 \$ 1.50$.

Poeticus ling Edward VII. A new and magnificent large flowering early variety, with broad round white llower of great substance and yellow cup edged deep red. Doz. 75c., $100 \$ 4.00,1000 \$ 35.00$.

Pocticus Grandiflorus. A new and large type of the late flowering Poeticus; very large and handsome flowers; pure white with yellow cup suffused with crimson. Doz. 60c., $100 \$ 3.00,1000 \$ 25.00$.

Poetaz Alsace. Pure white, with yellow, slightly reddish edged $\in$ ye. Very early. Doz. 75c., $100 \$ 5.00,1000 \$ 40.00$.

Poetaz Elvira. Pure white, with yellow eye; large free flowering; keeps well. Doz. $75 \mathrm{c} ., 100 \$ 5.00,1000 \$ 40.00$.

\section{Polyanthus Narcissus}

The Polyanthus varieties of Narcissus are not only beautiful, but deliciously sweetscented and of the easiest culture; very free. flowering, and suitable for window garden, conservatory or garden, continuing long in bloom. They bear tall spikes of bloom, bearing from six to twenty-four flowers each. The pure white petals and gold cups of some varieties, the yellow with deep orange cups of others, and the self whites and yellows render them great favorites.

If ordered by mail, add 20c. per dozen for postage.

Gloriosus. Immense trusses of pure white, with primrose-colored cups; very early; splendid to force. Ea. $5 \mathrm{c}$, per doz. $40 \mathrm{c}$. per $100 \$ 3.00$.

Grand Solcil d'Or. Rich vellow, with reddish orange cup, a favorite bedding and cutting variety. Ea. $5 \mathrm{c}$, per doz. $40 \mathrm{c}$, , per $100 \$ 3.00$.

Double Roman. Clusters of white flowers with double citron-colored cups. It is very early, and is grown largely for forcing. Ea. $5 \mathrm{c}$, per doz. $30 \mathrm{c}$, , per $100 \$ 1.5 n$.

States Goncral. Clusters of white flowers, With citron-colored cups, shading to white. Tery early. Ea. 5c., per doz. $40 \mathrm{c}$, per $100 \$ 3.00$.

White Pearl. Extra fine clusters of satiny white flowers, with citron-colored cups, profuse bloomer. Ea. 10c., per doz. $75 \mathrm{c}$, per $100 \$ 5.00$.

Mixed. all colors. Each 5c., doz. $45 \mathrm{c}, 100$

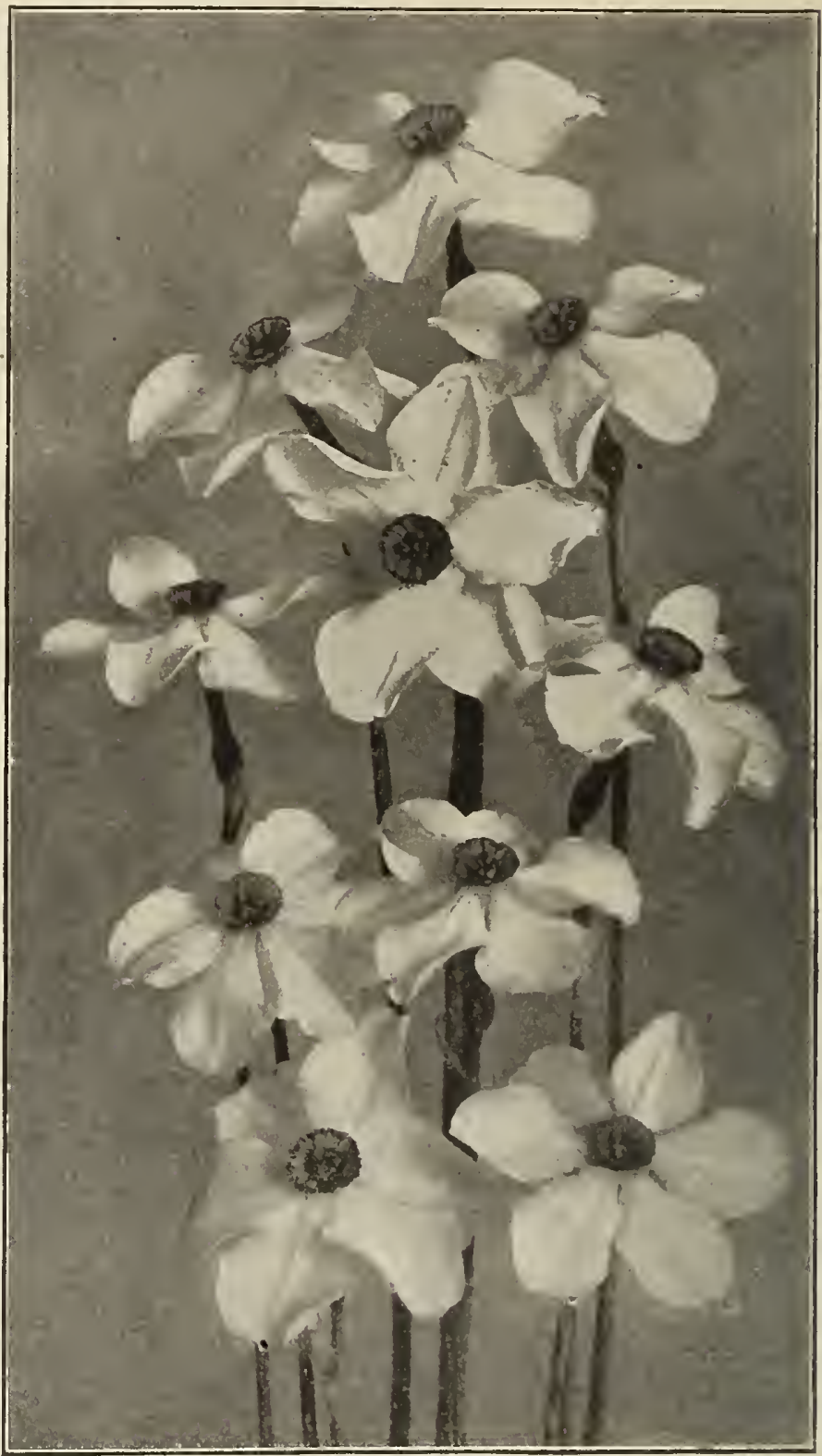

Narcissus Poeticus $\$ 2.00$.

\section{JONQUILS}

Much prized for their charming golden and deliciously swcet-scented flowers, perfectly hardy, and flowering very early in the Spring; they are also admirably adapted for Winter forcing.

siugle Jonquil. The well-known farorite, delicately scented and beautiful for forcing. Rich yellow, very fragrant. Per doz. $15 \mathrm{c}$., per $10075 \mathrm{c}$.

Double Jonquil. Heads of small, but rery double deep golden yellow flowers, powerfully scented and good for forcing. Ea. 5c., per doz. $35 \mathrm{c}$, , per 100 $\$ 2.50$.

Camperncllc. Large six-lobed rellow fowers, four th six on a stem, fine for forcing, and the one generally preferred by florists. Per doz. 15c., per 100 $\$ 1.00$.

Iiugulosus (The Giant Jonquil). Broadly imbricater? perianth, with large. wrinliled cup, full yellow Per doz. $25 \mathrm{c}$. , per $100 \$ 1.25$. 


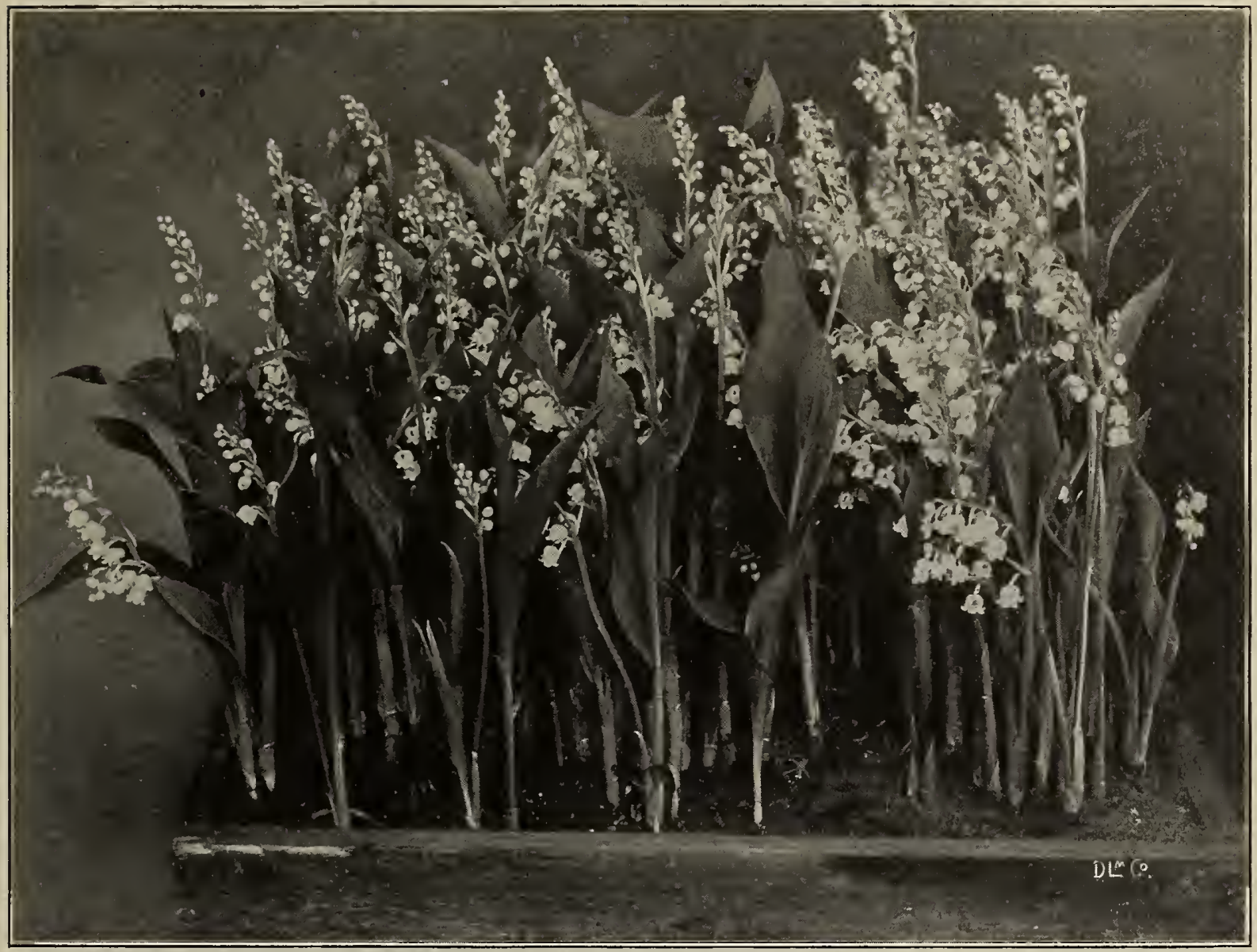

Flat of S. \& W. Co.'s Famous Russian Valley

\section{Stumpp \& Walter Co.'s Famous Russian Lily of the Valley}

The Russian Talley produces strong spikes of flowers, about 15 to 18 inches in height, bearing from twelve to twenty extra large pure white bells, which are delightfully fragrant. Feady for delivery December 1st.

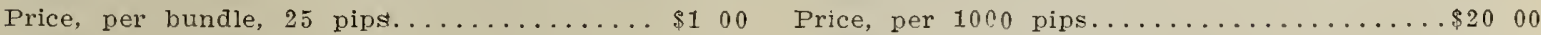
Price, 4 bundles, 100 pips............ 300 Price, per 2500 pips............. 450

\section{LILY OF THE VALLEY}

\section{CLUMPS FOR OUTSIDE PLANTING}

The most satisfactory of all the Spring flowering plants. Every garden should have at least a few clumps of these beautiful flowers. Planted once they last forever, with hardly any care. They are pcrfectly hardy, and increase in size from year to year; can be divided and transplanted, and are always sure to give a profusion of bloom.

Clumps that will produce from 12 to 15 flowers the first Spring: Each $35 \mathrm{c}$, doz. $\$ 3.50,100 \$ 25.00$.

Delivered anywhere in the United States. Order now for delivery during October. 


\section{S. E. W. Co.'s LILIUM HARRISII The True Bermuaa Easter Lily}

This beautiful Lily has pure white trumpet-shaned flowers, delightfully fragrant, which can be kept for two weeks after being cut. The bulbs are perfectly hardy, except in northern clymates, making it a desirable garden plant. Or they can be forced to bloom for Christmas by planting the bulbs in $A$ ugust, or be held back so as to bring them into bloom in time for Easter.

Complete cultural directions for forcing Liliums mailed upon application.

\section{Prices of Bermuda Easter Lily:}

First Size $\quad 6 \times 7 \quad \begin{gathered}\text { Each } \\ \text { Doz. }\end{gathered}$

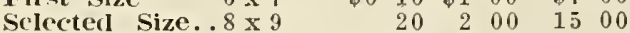
Extla Size...9 $11 \quad 35 \quad 3 \quad 50 \quad 2500$ Mammoth Size. 13 and over $\begin{array}{llllll}75 & 8 & 00 & 60 & 00\end{array}$

\section{HARDY LILIES}

L. Auratum (The Golden-rayed Lily of Japan). The flowers are pure white, thickly studded with crimson spots, while through the center of each petal runs a clear golden band. Fully expanded, the flowers measure nearly a foot across, are produced abundantly from June to October, and possess a most delicious fragrance. 3 to 5 feet.

8 to 9 -inch bulbs. $\$ 0 \quad 15 \quad \$ 150 \quad 510 \quad 00$ 9 to 11 -inch bulbs.. $\quad 20 \quad 2 \quad 25 \quad 1500$

11 to 13 -inch bulbs.. $\quad 40 \quad 3 \quad 50 \quad 2500$

13 to 15 -inch bulbs. $50 \quad 500 \quad 40 \quad 00$

I. Auratum Iiubrum Vittatum. A unique variety; flowers 10 to 12 inches across, ivory white, with broad crimson stripe through center of each petal. Each Doz. 100

9 to 10 -inch bulbs. $\$ 075 \quad \$ 6 \quad 50 \quad \$ 50 \quad 00$

L. Aluratum Wittei. A Lily of magnificent proportions; immense flowers; very tall and free-blooming; color creamy white, with gold bands. Each Doz. 100

9 to 10 -inch bulbs. $\$ \$ 0 \quad \$ 0 \quad \$ 900 \quad \$ 70 \quad 00$

T. Speciosum Album. Pure white; a grand variety.

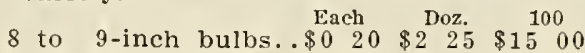

9 to 11 -inch bulbs.. $\quad 30 \quad 300 \quad 2000$

11 to 13 -inch bulbs.. $50 \quad 500 \quad 4000$

r. Spcciosium Ielpomene. Very rich crimson. $\quad$ Each Doz. 100

8 to 9 -inch bulbs. $\$ 0 \begin{array}{llllll} & 15 & \$ 1 & 50 & \$ 10 & 00\end{array}$

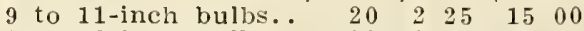

11 to 13 -inch bulbs.. $\quad 30 \quad 3 \quad 25 \quad 25 \quad 00$

I. Speciosum Rubrum. White ground, spot. ted rose on each petal; very hand-

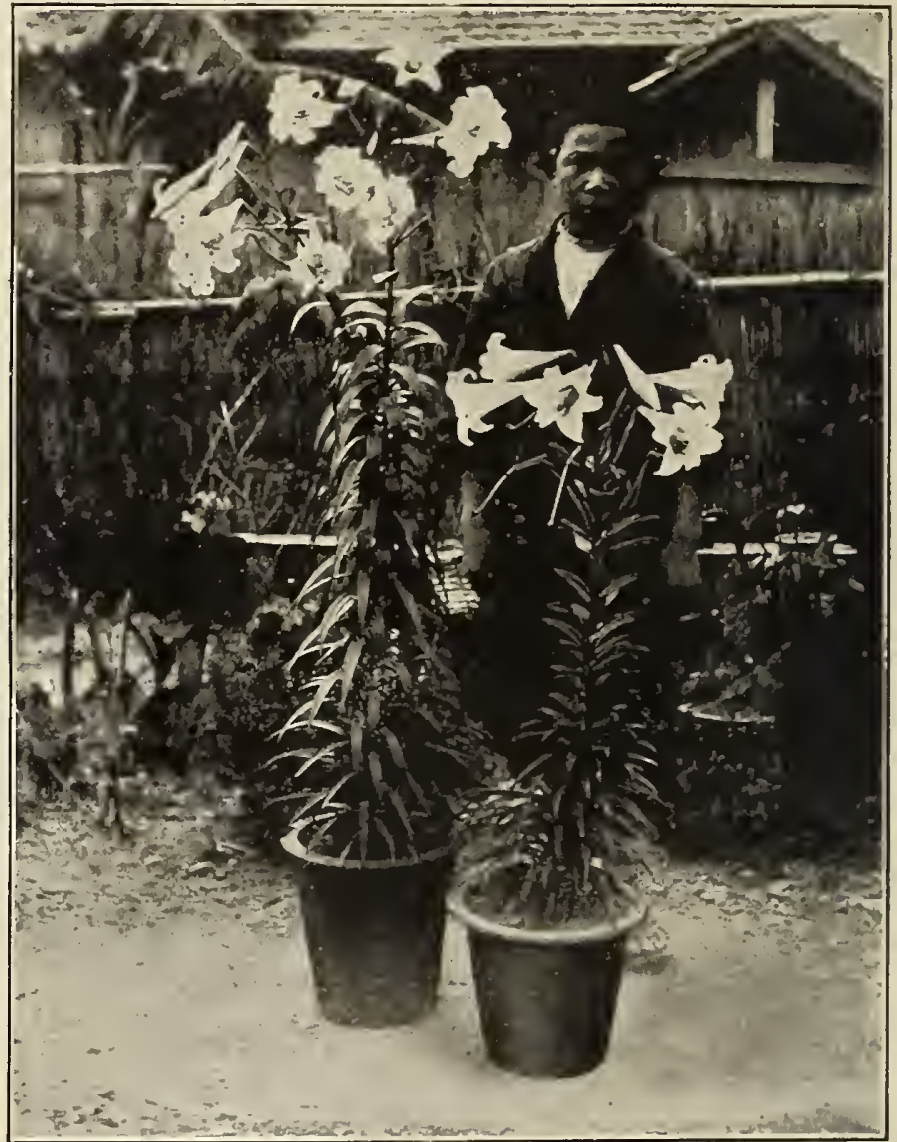

Lilium Formosum
8 to 9 -inch bulbs........ \$0 $15 \quad \$ 150 \quad \begin{array}{llll}\text { Fach } & \text { Doz. } & 100 & 00\end{array}$

9 to 11 -inch bulbs......... $20 \quad 2 \quad 25 \quad 15 \quad 00$

11 to 13 -inch bulbs........ $30,300 \quad 2000$

13 to 15 -inch bulbs........ $50 \quad 5 \quad 00 \quad 4000$

I. Japonicum Brownii. Laige trumpet-shaped flowers, 10 inches long; inside pure white, with delicately colored anthers outside brownish purple, tips of petals slightly recurved.

$\$$ to 10 -inch bulbs. Each 50c., doz. $\$ 4.50,100 \$ 30.00$.

I. Supcibum. In a collection of best plants of all countries, our native Superbum Lily would deserve a first place. In deep, rich soil it often grows 8 feet high, with twenty to thirty flowers. It is of the easiest culture, and may be grown as a wild flower in any swampy or rough part of a place where the grass is not mown. Extra selected bulbs, each $15 \mathrm{c}$, doz. $1.50,100 \$ 10.00$.

L. Tenuifolinm, A beautiful, graceful Lily, with crimson, reflexed flowers. Blooms in June. Each 20c., doz. $\$ 2.25,100 \$ 15.00$.

L. Tigrinum flore pleno. The Double Tiger Lily. The only double Tiger Lily worth growing.

5 to 7 -inch bulbs. Wach $15 \mathrm{c}$, doz. $\$ 1.25,100 \$ 8.00$.

I. Tigrinum splendens. Improved Single Tiger Lily. 8 to 10 -inch bulbs, Wach $15 \mathrm{c}$, doz. $\$ 1.50,100 \$ 12.00$.

L. Elegans Incomparablc. Red; extra fine. Each $20 \mathrm{c}$, doz. $\$ 2.25,100 \$ 15.00$.
L. Formosum. A new early flowering Easter Lily; good forcer; free from disease.

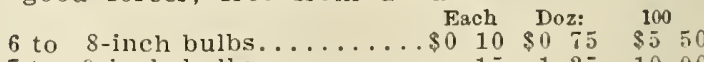

7 to 9 -inch bulbs.............. 15 1 1251000

7 to 9 -inch bulbs, selected. $\quad 20 \quad 17501250$

9 to 10 -inch bulbs, selected.. $20200 \quad 1500$

L. Longiflorum IItliflorum. Each Doz. 100

7 to 9 -inch bulbs......... $\$ 0 \quad 10 \quad \$ 1 \quad 00 \quad \$ 750$

9 to 10 -inch bulbs......... $20 \quad 2 \quad 00 \quad 1400$

11 to 12 -inch bulbs........

L. Gioantcum. The dark-stenmed Japan grown Easter Lily; flowers extra large; fine plant, but a little later flowering. The best of all the Lilies.

6 to 8 -inch bulbs........ \$0 10 \$0 $75 \quad \$ 550$

7 to 9 -inch bulbs........... $15 \quad 150 \quad 1000$

9 to 11 -inch bulbs........ 20 1 $75 \quad 1500$

11 inches and up. Extra... $30 \begin{array}{lllll}30 & 3 & 50 & 25 & 0\end{array}$

I. Candidum (Annunciation, Madonna or St. Joseph Lily). The well-known garden Lily, snow white, fragrant blossoms: it is also one of the best forcing Lilies for florists; 3 to 4 feet; blooms in the open ground about June.

$$
\text { Fach Doz. } 100
$$

1st Size Bulbs........... \$0 $15 \$ 150 \$ 1000$

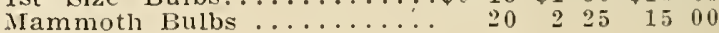
Jumbo Bulbs .......... $30 \quad 300 \quad 2200$ 


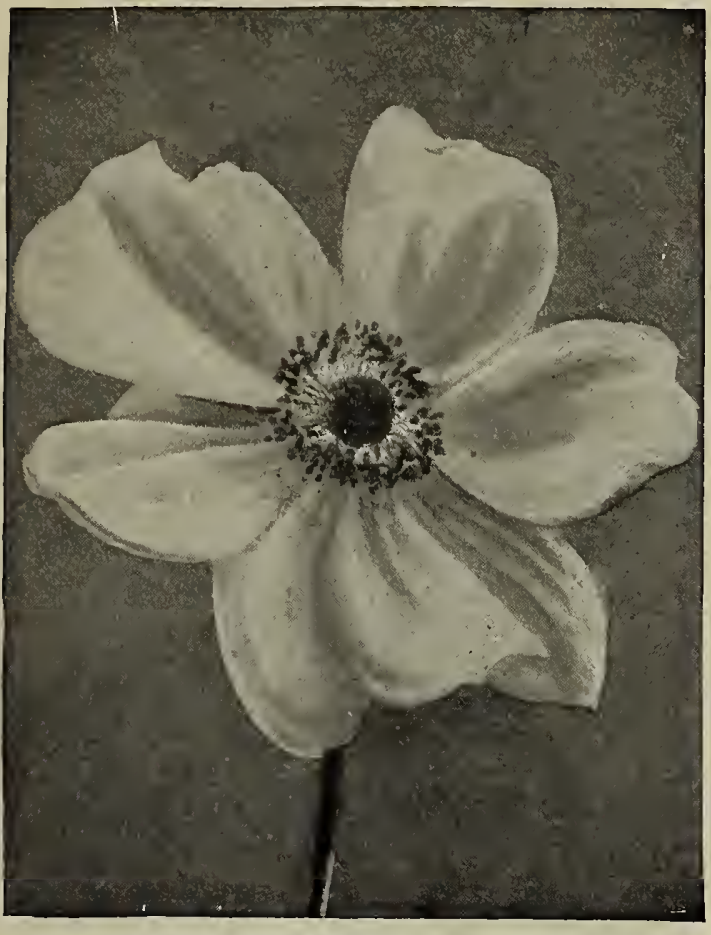

Anemones

\section{ANEMONES}

Very showy flowering plants, valued for their hardy nature, and also because they will flower at any required season, according to the time the roots are kept out of the ground. May be grown in pots or forced in frames.

Single Poppy Flowered. These handsome Single Anemones have large, beautiful saucer-shaped, Poppy-like blossoms, flowering continuously throughout spring and early summer. Each. Doz.

Helen Maria. Blue...........\$0 05 \$0 40

The Bride. Pure white........ $05 \quad 40$

Scarlet. Very brilliant......... $05 \quad 40$

Single Mixed ......40 ets. per doz.; $\$ 2.50$ per 100 .

\section{DOUBLE FLOWERING VARIETIES}

Each. Doz.

Celeste, Blue ............\$0 05 \$0 40

Ceres. White, veiled with rose... $10 \quad 75$

Cramoisi, Royal. Brilliant crimson $05 \quad 40$

Josephine. Scarlet ............ $05 \quad 40$

Lord Derby. Splendid bright rose 0540

Double Mixed ....40 cts. per doz.; $\$ 2.50$ per 100 .

Anemone Fulgens. The rich, dazzling, scarlet flowers and light, elegant growth render it the most attractive flower of Spring. It is valuable for cutting, as it lasts a long time. Each, 5 cts.; per doz., 35 ets.

Fulgens fl. pl. A double flowering variety of the above, very beautiful. Each, 5 cts.; per doz. 50 cts.

\section{Cyclamen Persicum Giganteum}

WVe have a magnificent strain of this most desirable greenhouse bulb, which has been grown especially for us, and which we know to be far superior to any stock heretofore offered.

Large Size Bulbs. Each, 15 cts.; per doz., $\$ 2.00$.

\section{CROWN IMPERIALS}

Well-known hardy border plants, bearing clusters of immense pendent bell-shaped flowers, surmounted with a tuft of green leaves. They do better if planted in good rich soil and may be left undisturbed for years.

If ordered by mail add 5 cts. each for postagc.

Aurora. Red ................... \$ach. Crown on Crown. Several whorls of flowers,

one above the other............. 20

Gold Striped. Crimson, variegated foliage.. 25 sulphureus. Sulphur-yellow ........... 20 Mixed Varieties .................. 10

\section{CHIONODOXA,} or Glory of the Snow

Most charming Spring-flowering bulbs. They produce flower-spikes bearing ten to fifteen Scilla-like flowers. They are perfectly hardy, and will thrive in any good garden soil. Fine for pot culture for winter-blooming.

Luciliae. Bright blue, with clear white center. Each, 2 cts.; per doz., 20 cts.; per $100, \$ 1.25$.

Sardensis. Very deep blue. Each, 3 cts.; per doz., 25 ets.; per $100, \$ 1.25$

\section{AMARYLLIS}

All the varieties in this list are of the easiest culture; the great secret being to give them alternately a season of growth and one of rest. To do this well, the plants should be abundantly supplied with water and heat, and placed near the glass when they are coming into flower, and water should be withheld from them gradually when they have ceased flowering, when they should be laid away in a dry, cool place. The soil suitable for their culture is a rich loam, one-fourth part of well-rotted manure and a slight proportion of sand.

If ordered by mail, add 5 cts. each for postage.

Each.

Belladona Major. Large violet and white.....\$0 15 Equestris. (The Barbadoes Lily.) Bright orange scarlet, with white throat...........

Formosissima. (Jacobean Lily.) Brilliant scarlet.

Johnsonii. Crimson, striped with white....

Defiance. Carmine-red, bars white, running

through petals ................ 100

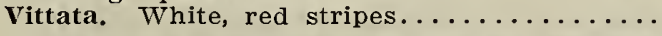

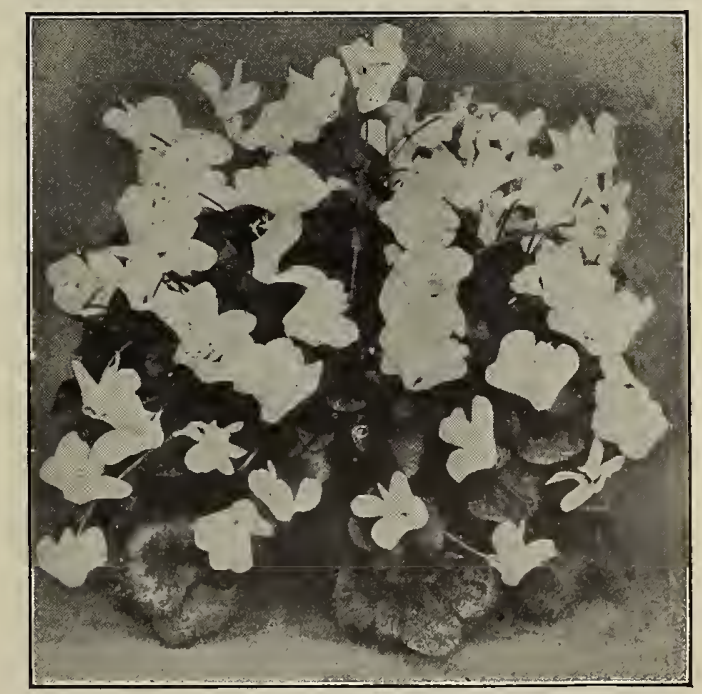

Cyclamen Persicum Giganteum 


\section{GLADIOLUS}

Our bulbs are grown and selected especially for the greenhouse; are all the largest of the respective sizes.

$\begin{array}{llll}\text { Doz. } & 100 & 1000\end{array}$

I'each Blossom. Most delicate pink, a very popular variety. .

Blushing Bride (Delicatissima). Rosy white with carminc blotch. One of the most useful Gladiolus ............. Queen Wilhelmina. Delicate pin: with dark pink blolch...... Sapplio. Soft lilac, with writc and violet blotch..........

Queen of Holland. White with soft pink blotch.........2 0001200

America. Selected extra large bulbs .................. $125700 \quad 60$

May. Selected extra large bulbs $60 \begin{array}{llll}3 & 25 & 25 & 00\end{array}$

Prineeps. Selected extra large bulbs ............... 20001500

\section{GLOXINIAS}

\section{S. E W. Co.'s Superb Strain}

Empcror Frederick. Red, bordered white. Emperor William. Violet, bordered white. Prineess Elizabetl. White, bordered blue. Iont Blane. Pure white.

Violacea. Dark violet.

Madame Ifelenc. White, crowned violet.

Princess Matlilda. White, bordered rosc.

Queen Victoria. Dark rose.

Defiance. Scarlet.

King of the Reds. Deep scarlet.

Prince Albert. Dark violet.

Finest Mixed.

Each $15 \mathrm{c} .$, doz. $\$ 1.50,100 \$ 10.00$.

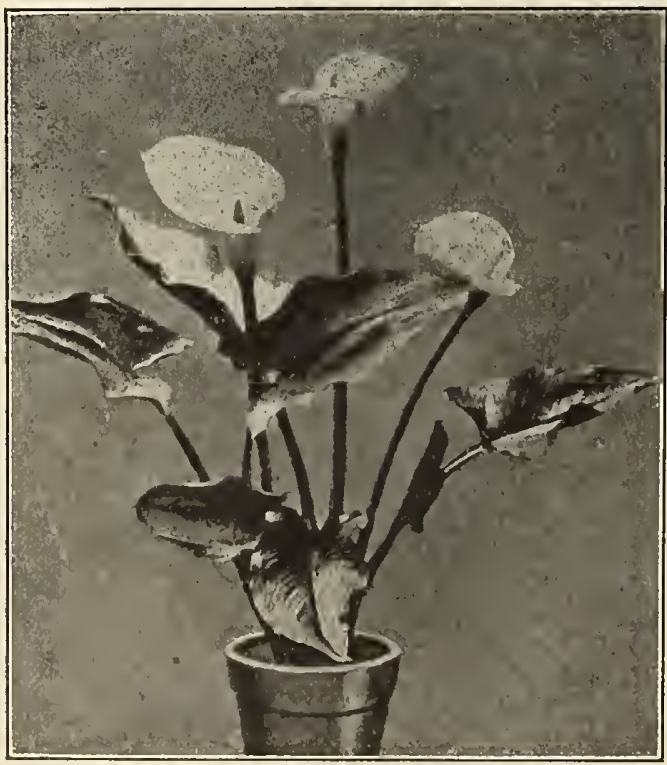

Calla

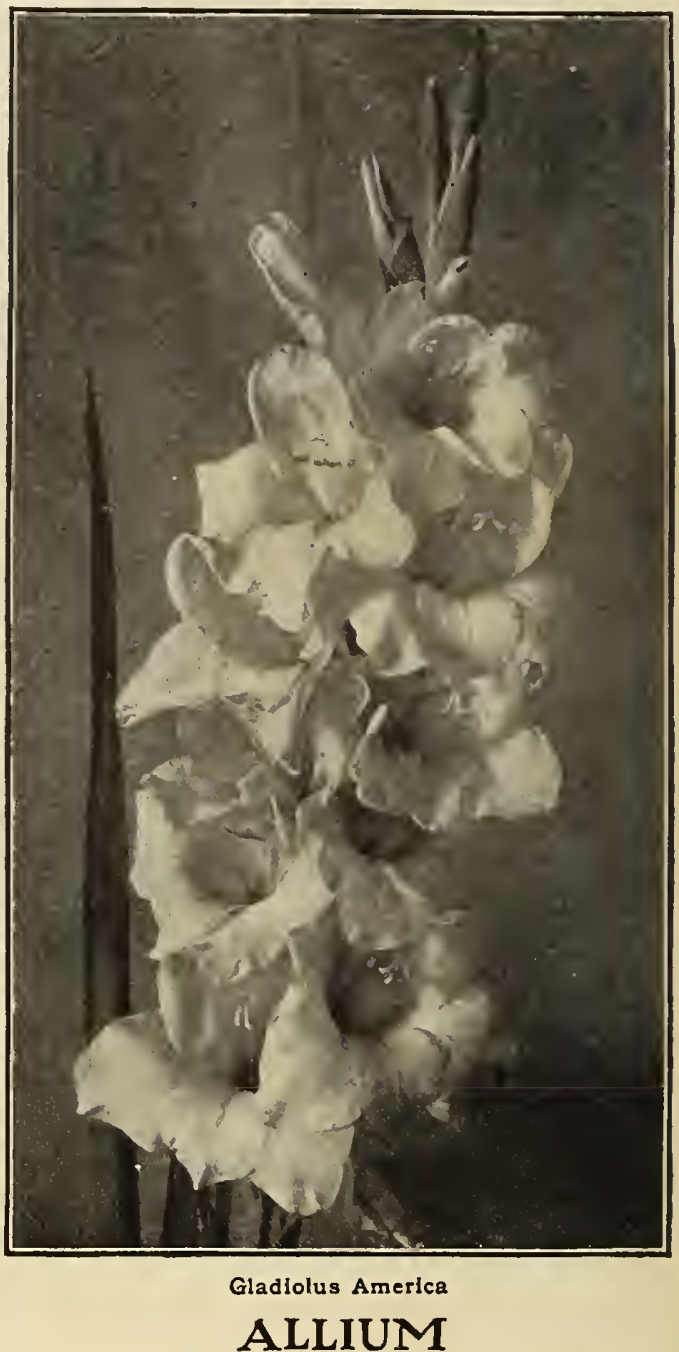

The varieties we offer are among the most beautiful for pot culture or garden decoration. They are of the easiest culture.

Neapolitamm. Another excellent variety for $\pi$ inter flowering, now extensively forced by florists for cut flowers, being of pure white, with green stamens, borne in large loose umbels; height, 15 to 18 inches, 6 for $10 \mathrm{c} .$, doz. $15 \mathrm{c}, 100 \$ 1.00$.

\section{CALLAS}

A well-known plant, of easy culture: the only particular attention it requires is constant watering. and as warm a room as can be conreniently giren it. Ist Size Bulbe............... Each Doz. 100 Extra Size Bulbs .......... $25 \quad 2 \quad 50 \quad 1500$ Jumbo Bulbs . . . . . . . 50 5 $500 \quad 3500$

\section{IXIAS}

Very desirable for pots or for the open ground. They require for outcloor planting the sume treatment as Dutch Hyacinths, except that they should be more hearily mulched.

If ordered by mail, add se. per doz. for postage. Extra Choice Mixture of 25 named varieties. Each,

$5 \mathrm{c}$, doz. $25 \mathrm{c} ., 100 \$ 1.25$. 


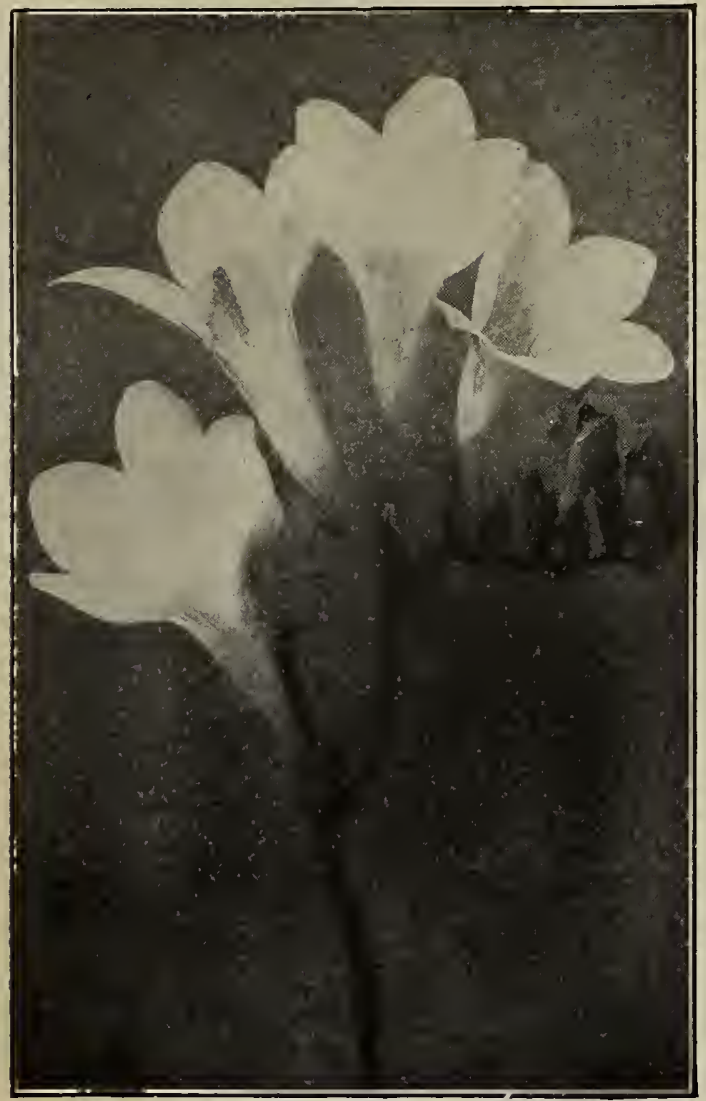

Freesia Purity

\section{FREESIAS}

Refracta Alba. Pure white; yellow throat. One of the most popular and charming bulbs for pot culture, flowering in the Winter in the conservatory or window garden. They force very easily, and can be had in bloom by Christmas if started in pots in the month of September. Plant half a dozen bulbs in a four-inch pot, in good rich soil, water well, and keep them at a temperature of 60 degrees. By having a number of pots in a cold frame they can be brought in at intervals, thereby having a succession of blooms through the vinter.

\section{FREESIA REFRACTA ALBA}

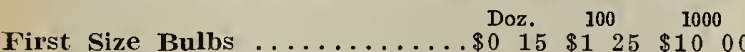

Manumoth Bulbs .......... $25 \quad 1 \quad 75 \quad 15 \quad 00$

Jumbo Bulbs ............ $40 \quad 2 \quad 25 \quad 2000$

Fischer's Purity. The finest pure white Freesia; strong stiff stems; pure white flowers.

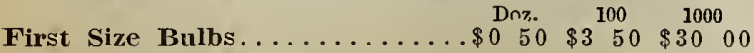

Mammoth Bulbs .......... $75 \quad 4 \quad 50 \quad 40 \quad 00$

\section{RANUNCULUS}

Very charming. dwarf-flowering, of various bright and attractive colors. Plant late in Autumn, about three inches deep and protect by straw or leaves.

French Mixed $\ldots \ldots \ldots \ldots \ldots \ldots \ldots 0 \quad 05 \quad \begin{aligned} & \text { Each } \\ & \text { Doz. }\end{aligned}$

Persian Mixed ............ $05 \quad 20 \quad 1 \quad 00$

Turban Mixed. Hardiest sort.. $05 \quad 20 \quad 100$

\section{THE BERMUDA "BUTTERCUP" OXALIS}

An unrivaled Winter-Flowering pot plant of the easiest sulture, succeeding with everybody

This is one of the finest flowering plants for pot culture that we have ever seen; it is such a strong, luxuriant grower that one bulb will be sufficient for a 6 or 8 -inch pot. Place. in a dark, cool position for several days to root thoroughly, and remove to a sunny situation in the window or conservatory in a temperature of about 60 degrees Fahr., and the great profusion of bloom produced in uninterrupted abundance for weeks will astonish and delight you. The flowers are of the purest bright buttercupyellow. Well-grown plants have produced as high as seventy flower stems at one time, and over 1,000 flowers in one season. Properly treated, the plant will flower in six weeks from the time the bulbs are planted. Each $3 \mathrm{c}$, doz. $30 \mathrm{c}$.

\section{OXALIS}

Very desirable and charming plants, particularly adapted for pot culture in the greenhouse or window garden. Plant the bulbs in September or October and keep in a moderate temperature. They are of the easiest culture and will bloom profusely during the Winter months.

Alba. White. Each 3c., doz. 25c., $100 \$ 1.75$.

Bowiei. Crimson. Each 3c., doz. 25 c., $100 \$ 1.75$.

Lutca. Yellow. Each 3c., doz. 25c., $100 \$ 1.75$.

Lutea, fl. pl. Double yellow. Each 3c., doz. $25 \mathrm{c}$., $100 \$ 1.75$.

Rosea. Rose. Each 3c., doz. 25 c., $100 \$ 1.75$.

Versicolor. Crimson and white. Each $3 \mathrm{c}$., doz. $25 \mathrm{c}$., $100 \$ 1.75$.

Mixed. Each 3c., doz. $25 \mathrm{c} ., 100 \quad \$ 1.00$.

\section{SPARAXIS}

They were formerly included in the genus Ixia, and bear a close resemblance to them; the main points of difference being that the sparaxis are of more compact habit of growth, the flowers more bold, and somewhat larger and the flower spikes are not more than half as high, rarely growing more than six inches. Especially desirable for the window curtain.

If ordered by mail, add 5c. per doz. for postage. Splendid Mixed Varieties. Doz. 20c., $100 \$ 1.25$.

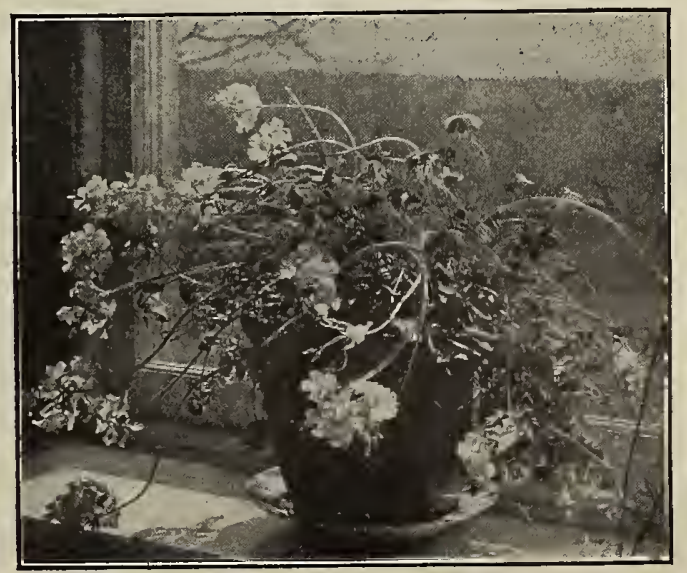

Oxalis 


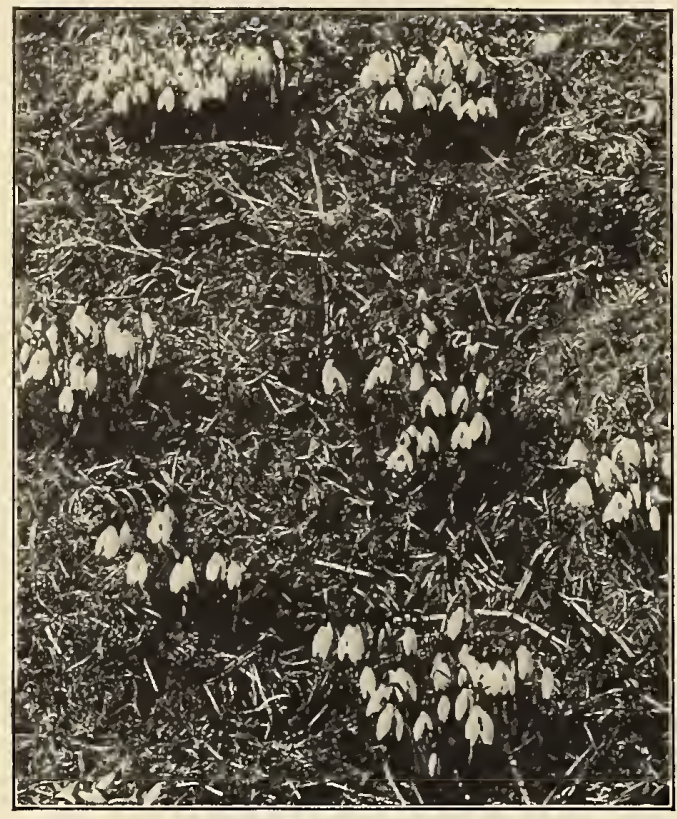

Snowdrops

TRILLIUM

Grandiflorum. (Great American Wood Lily.) This is one of the most beautiful American plants, perfectly hardy, growing and flowering profustly in partially shady nooks about the lawn, under trees, etc. The flowers are large, of the finest white, changing in a few days to soft rose; if grown several in a pot, it makes one of the best white Winter flowers. Each, 5 cts.; per doz., 50 cts.; per $100, \$ 3.00$.

\section{TRITONIA}

Exceedingly bright and free blooming bulbous plants, highly valuable for both garden and pot culture. A dozen roots in a 10-inch pot will, in the Autumn, make a beautiful display. The bulbs should be grown in pots, in a cold frame, during Winter, and they can either be brought into the conservatory toward Spring for blooming or the bulbs can be kept dormant and planted out in May, like Gladioli, and then be lifted in the Autumn for Winter blooming.

Mixed Colors. 3 for 10 cts.; per doz., 30 cts.; per $100, \$ 2.00$.

\section{Ornithogalum Arabicum}

\section{(Star of Bethlehem)}

Very desirable for pot culture in the window garden. The flowers are large, pure white, with a black center, borne on a tall spike. In pots they should be treated in the same manner as the Hyacinth. At 100 rate buyer pays transit. Each, $10 \mathrm{cts}$; per doz. 40 cts.; per $100, \$ 2.50$.

\section{SNOWDROPS}

These elegant little flowers, the first to open in spring, should be found in cvery garden, not only because they are the earliest Spring flowers, but because they are the loveliest. The Snowdrop thrives in almost any situation or soil, and should be planted as early in the Autumn as possible, as they suffer much if left long out of the ground.

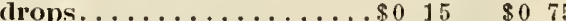

Donble .................... $25 \quad 175$

Elwesii, Giant Snowdrops......... $25 \quad 100$

\section{STERNBERGIA}

s. Lutea. Large, pure yellow. Crocus-like flowers, which are produced with the leaves during late Autumn. This is supposed by some writers to be the true Lily of Scriptures, as it grows abundantly in the vales around Palestine, etc. 3 for 10 cts.; per doz., 30 cts.; per $100, \$ 2.00$.

\section{SCILLAS}

Most charming and desirable Spring Howering bulbs. The flowers resemble the Hyacinth, but are much smaller; their colors are more intense, and they come into flower much earlier. As an edging, or for filling small beds, if planted sufficiently thick, the effect is matchless. Treat in the same manner as Hyacinths for outdoor culture, or for pots in the window garden.

Sibiriea, dark blue...........\$ $25 \quad \$ 150$ " mammoth bulbs.......... $40 \quad 200$ Campanulata, white.......... 25

“ $\quad$ rose $\ldots \cdots \cdots \cdots \cdots \cdots \cdots \cdots \cdots \cdots \cdots$

\section{SPIRAEA}

GLADSTONE. Two new Spiræas of recent introduction. The trusses are as white as snow, and supported on good, strong stalks $1 \frac{1 / 2}{2}$ feet long, and standing well erect, and emitting an agreeable odor. Plants often produce from 30 to 40 of these trusses. Each, 35c.; doz., $\$ 3.00 ; 100, \$ 16.00$.

S. Japonica ............... \$0 15 . $\$ 150$ S. Astilboides Floribunda ........ $20 \quad 200$ S. Nana Compacta Multiflora....... $25 \quad 250$

NEW PINI SPIRAA, QUEEN ALEXANDR. Entirely new departure in Spiræas introduced this year for the first time. Of a clear pink color with dense compact spikes; the plants are most attractive and equally as strong and vigorous as the white varieties. One of the most interesting novelties of recent years. Per doz., \$4.00; per 100 , $\$ 30.00$.

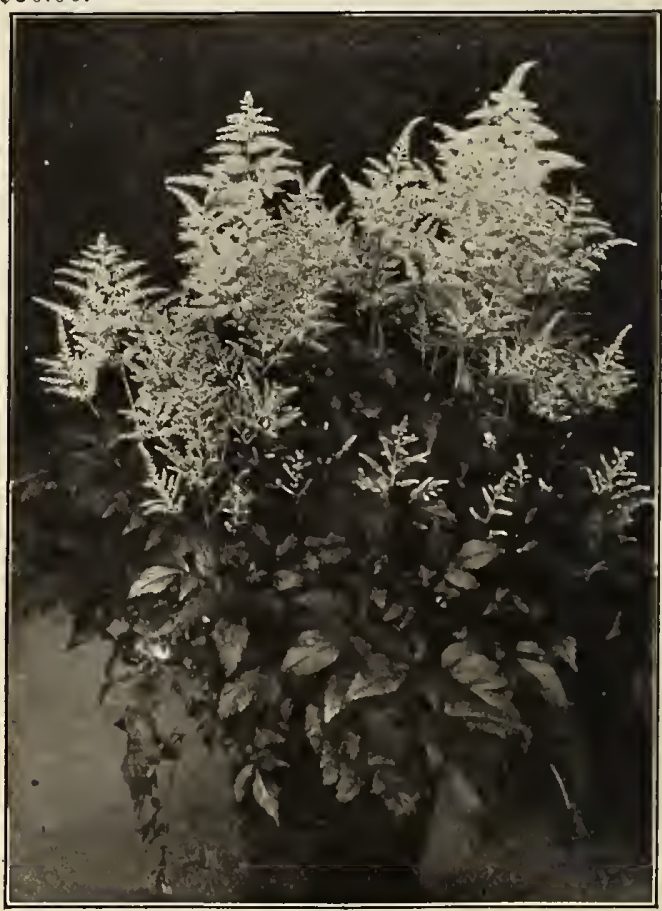

Spiraea Gladstone 


\section{PEONIES}

Agnes Mary Kelway. Outer petals losy Each Doz. pink, center yellowish; one of the earliest to $\mathrm{flower} \ldots \ldots \ldots \ldots \ldots . . . . . . . .50 .50$

Agida. Dark red; fine full flower....... . . J

Alba Plena. Pure white; fine strong plant, good for cut flowers............

Boule de Neige. Sulphur white. with carmine tips on some of the petals......

Caroline Allain. Blush white........

Canary. White tinted primrose; rers handsome, large, full flower..........

Charles Leveque. Delicate rose, large erect flower, very pretty when partly open: ane of the finest rose-colored varieties ...................... 1.00

Cytheria. Creamy white tinted rose; an exceptionally fine cut flower variety, very strong stem and a good grower........

Duchesse de Nemours. Pure white, perfect flowers, extra fine.............

Duke of Wellington. White yellowish center; perfect flower; very fragrant...

Festiva Maxima. Farly; very large and full shell-shaped Hower, often 6 to $\delta$ inches in diameter, stems 3 to $31 / 2$ feet; color snow white shading to delicate creamy white at base of petals, with an occasional clear purple spot on edges of center petals; very fragrant. The finest

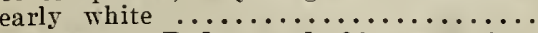

Fragrans. Red; good bloomer; long stems; a very good variety...........

Francis Ortegal. Purplish crimson....

Hamlet. Red; good flower............

Hume: Carnea. Clear cherry pink; strong grower: large, very full, highly cinnamon-scented flower: very late; graceful habit. An excellent rariety for

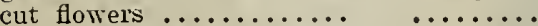

Lady Leonora Bramwell. Compact. rigorous habit; color delicate silvery pink shaded lilac and chamois; three nankeen petals tipped with crimson at the center; good keeper and shipper..............

Mary Lemoine. Very large; ivory white bloom shaded pink and chamois; strong stems of medium height; late bloomer; excellent variety; scarce............1.0

Mme. Calot. Pinkish white tinted with flesh color ................... .

President Roosevelt. Fxtra large floter, fine scarlet, good keeper......... 1.00

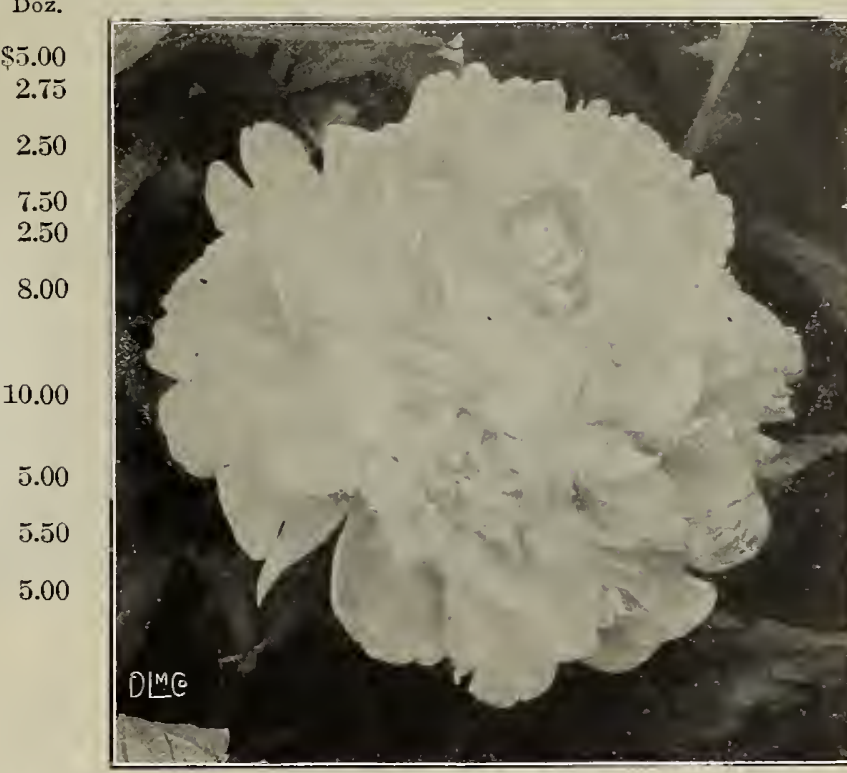

Festiva Maxima

5.00

3.50

5.00

2.50

Pulcherrima. Rose violet. center rose Each and salmon; a good rariety for collection ..................... $\$ 0.20$

$\$ 2.00$

Queen Victoria. Large, full, compact bloom, with fine broad guard petals: opens flesh white center petals tipped mith red blotches. One of the best cut flower varieties, as it is an exceptional shipper and keeper..................

Reevesii Plena. Rosy flesh, red blotch

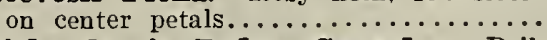

Richardson's Rubra Superba. Bril7.50 liant deep crimson; the latest of all Peonies to bloom; very fragrant; the

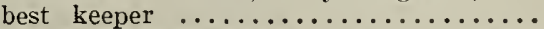

Rubra Triumphans. Rich gloming crimson $\quad \ldots \ldots \ldots \ldots \ldots \ldots \ldots \ldots \ldots$.35

Pink Shades Mixed........ \$0.20

Red Shades Mixed.......... .25

\section{Japanese or Anemone Flowered PEONIES}

Our stock of Herbaceous Peonies is imported direct from our grower in Japan and our collection of these embraces the finest and best varieties in the world. While the price that we ask for them may seem rather higl remember the roots that we offer are large, undivided field grown, and about four times the size of those generally supplied by other dealcrs.

No. 1. Pink tipped white variegated center.

No. 2. Blush petals, large full chrysanthemum center.

No. 3. Pink tipped white, white shaded center.

No. 5. Rose shaded white, crimson tipped $w$-ith orange center.

No. 6. Blush with rose at base of petals, yellow center.

No. 11. Purplish rcse with variegated center, rery haudsome.

No. 13. Rose and white with dark rose at base of petals, full orange center.
No. 14. Tiolet red, full rariegated sellow and marocn center.

No. 16. Ilandscme pure white.

No. 23. Tert shading to wine color. chrysanthemum shaped center of gold.

No. 26. Tristed and curred petals of rose, crrdinal white, rariegated center.

No. 27. Solid dark scarlet red, rers handsome.

Price. each 75c.; collection of 12 named rarieties as above. \$7.50. 


\section{HARDY SHRUBS}

All Shrubs: Each 50c., doz. \$4.50, unless otherwise priced.

Our Shrubs are all large, carefully selceted plants, and can be sent by cxpress only, purcliaser paying express charges. Special priees giveu ou quantities.

\section{CALYCANTHUS FLORIDUS}

\section{(Strawberry Shrub)}

An interesting shrub, having a rare and peculiar fracrance of nood and flowers; its blooms are abundant and of a peculiar chocolate color. 2 to 3 feet.

\section{CARYOPTERIS (Blue Spiraea)}

A pretty Autumn blooming plant; prodnees clusters of fragraut blue flowers.

\section{CYDONIA (Japan Quince)}

C. Maulei. Beautiful orange-colored floters, a distinet shade; fine.

C. Jap. atrosanguinea. A handsome rariety witl semi-double scarlet flowers.

\section{CORNUS (Dogwood)}

C. Sikirica. A rare and remarkable variety with bright, red bark in Winter.

C. Sibirica. Variegated foliage, a very pretty variety.

C. Spathei. Foliage pale yellow and green.

\section{DAPHNE}

D. Mezereum. White, small ercet branches; clusters of pink flowers in March.

D. Mezereum. Red, rery pretty red flowers.

\section{DEUTZIA}

D. gracilis. Of a dwarf, bushy habit: the raeemes of white flowers completely cover the plant, waking it one of the most attraetive shrubs of the season, blossoming iu June.

D. Lemoinei. The branches are entirely corered with erect panicles of large, snow-white flowers, quite distinct from all other Deutzias; one of the hest dwallf varieties; fue for forcing.

D. Pride of Rochester. It excels all the older sorts. in size of flower, lengtl of pauiele, profuseness of bloom and rigorous habit.

D. Wateri. A new free-flowering, dounle white rariety.

\section{EXOCHORDA (Pearl Bush)}

E. grandiflora. A fine 'shrub, produeing larse white flowers in May.

\section{FORSYTHIA}

F. viridissima. Bright yellow flowers, which appear early in the Spring.

F. suspensa. Jellow flowers, droopiug habit.

\section{FLOWERING CURRANTS}

The Flowering Currants a re gay, heatiful slirubs in early Spring. and of the casiest eulture. White flow crini, red flowering, yellow floweriug.

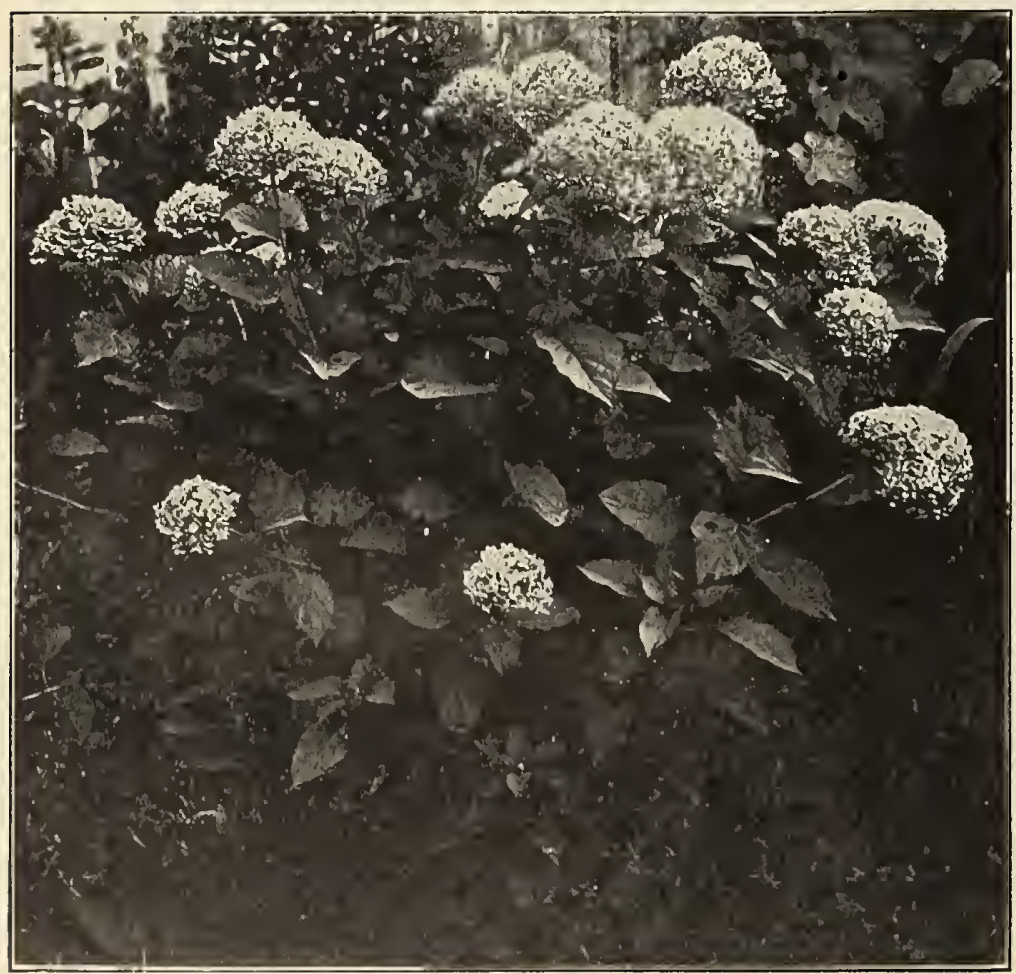

Hydrangee arborescent grandiflora-" Hills of Snow"

\section{GENISTA}

G. sagittalis. I finc dwarf perennial; flowers pea-shaped, yellow, in a terminal spike.

\section{HYDRANGEA}

H. arborescens grandiflora (IIills of Snow). This superb uew IIy draugea is a variety of the hardy uative species II. arborescens, commouly found "wild" in most of the States east of the Mississippi liver: The variety graudiflora is likewise absolutely hardy aud is, moreover. of casy culture and is an exceedingly prolific bloomer. A five-ycar-old plant has produced one hundred aud twenty-six perfect blooms at onc time. The size of the flower is onc of the striking features of this slirub. Twelvcincl blooms are freguent on young plants, while the average size on matured plants is usually six inches or molc. 'The rolor of the flower is a pure snow-like whitc. without the crearuy and later pink tints that are eharacteristic of the 11 . paniculata erandifora. The lengtli of time this whiteness is retained depeuds somewhat on local conditions, but usually from four to five weeks, when the flower's begin to changc slowly and gradually to a liwht green color, and by October the foliage and flowers are of a similal' shade. 'The fowcr clusters 
HYDRANGEA-Continued

remain intact long after the leaves have fallen, and frequently throughout the following Wiuter. 'This Hydrangea gives every promise of becoming eren more popular than the well-known H. paniculata grandiflora, as it lacks the coarseness and stiffness of that variety; it is refined in tone and effect. and with its abundant and handsome foliage it lends itself readily to landscape effects. It is a comely. handsome shrub at all times. It reaches a height of five to six feet. and when in full bloom is one of the most striking as well as the most beautiful shrubs of its season, suggesting the descriptive synonym referred to in Bailey's " $\mathrm{Cy}$. clopedia of American Horticul-" ture," viz., "Hills of Snow." Strong, two-year-old plants, each $\$ 1.00$, doz. $\$ 10.00$.

H. paniculata grandiflora. One of the most popular shrubs in cultivation, blooming at a time when few other shrubs are in flower; bearing immense panicles of pure white flowers, which appear in August, turning to a delicate pink and remaining till late in the

Autumn. Spikes of flowers have been known to measure 12 inches long by 22 inches in circumference. Extra strong plants, 5 to 6 branches. Standards about 5 feet high, extra fine. Each $75 \mathrm{c}$., doz. $\$ 8.00$.

H. Hortensia (Garden Hydrangea). A well-known variety, used for porch decoration and Easter forcing. The flower heads are large, showy and of a pretty pink tint which may be changed to blue by the use of iron filings in the soil.

H. Otaksa. Of vigorous growth, especially in rich moist soil, heary, dark green foliage; large heads of beautiful rose-pink flowers, blooming freely when quite young. Each 50c., doz. $\$ 4.50$.

\section{HIBISCUS (Rose of Sharon)}

This has become one of the most popular flowering shrubs, coming in flower, as it does, in July and August, when few shrubs are in bloom. The entire plant is covered with beautiful double flowers, which, at a distance, look like roses. They make a very pretty flowering hedge. Three years old in ten separate varieties. single and double, in white, blush, shaded, blue, purple, red, violet, pink, shaded, yellow.

\section{HONEYSUCKLE (Upright)}

The following rarieties are of erect, shrubby habit, valuable for their showy fruit. The climbing sorts will be found under head of Hardy Vines and Creepers:

Morrowii. A very fine variety from Japan, valuable for its handsome red fruit.

Tatarica Rose. Pink flowers which contrast beautifully with the foliage.

Tatarica alba. Forms a high bush, with creamywhite fragrant flowers.

Tatarica grandiflora. A beautiful shrub, producing large red and white flowers.

\section{HYPERICUM}

H. Moserianum. The showiest of all the varieties and a novelty of decided merit. Of dwarf, half-pendulous habit; fine for massing; elegant, glossy foliage; the largest blossoms of the whole family, having orangevellow petals and a beautiful red mass of stamens in the center, produced freely from Midsummer until hard frost.

All Shrubs: Each 50c., doz. \$4.50, unless otherwise priced.
KERRIA

IX. Japonica. A slender, green-branched shrub, covered with a profusion of globular yellow flowers from July to October.

IX. variegata. A dwarf variety from Japan, with small, green foliage, edged with white. One of the prettiest and most valuable of dwarf shrubs.

\section{LILACS}

(Our pot-grown Lilacs will produce 10 to 15 flowers the first season.)

L.Chas. X. A strong, rapid growing rariety, with large, shining leaves; trusses large, reddish-purple. Pot grown, extra fine. Each $\$ 1.25$, doz. $\$ 12.00$.

L. Marie Legraye. Large panicles of white flowers, valuable for forcing. The finest white Lilac. Potgrown plants. Each $\$ 1.25$, doz. $\$ 12.00$.

L. Souv. de L. Spath. Panicles Iong; individual flowers large, single; dark purplish red; the finest of its color. Pot-grown plants. Each $\$ 1.25$, doz. $\$ 12.00$.

Standard or tree-shaped, 7 feet high, best named varieties. Each $\$ 2.50$, doz. $\$ 25.00$.

\section{MAHONIA (Ashberry)}

M. aquifolia. A native shrub of medium size with large, shining, prickly leares, similar to those of the famous English Holly, which turn scarlet in the Fall; bright yellow flowers in May, succeeded by bluish berries.

M. Japonica. A new variety from Japan, with very broad, spiny foliage of a light green color; yellow flowers in May.

\section{PRUNUS}

P. triloba (Double-Flowered Plum). Native of China. A highly interesting and desirable addition to hardy shrubs; flowers double, of a delicate pink, upward of an inch in diameter, thickly set on the long, slender branches; flowers in May.

\footnotetext{
Our Shrubs are all large, carefully selected plants, and can be sent by express only, purchaser paying express charges. Special prices given on quantities.
} 


\section{SAMBUCUS (Elder)}

S. Goiden Elder. One of the most showy shrubs grown, on account of its golden foliage. Very desiruble for ornamenting Jawns: with I'runus I'issardi there is nothing finer.

S. laciniata. I valuable valiety, with elegantly divided leaves; one of the best cut-leaved shrubs.

S. Weeping. A fine drooping variety.

\section{SNOWBERRY}

S. racemosus. A well-known shrub, with small pink flowers, and large white berries that hang on the plant tbrough part of the Winter.

\section{ST APHYLEA (Bladder-Nut)}

S. Colchica. One of the finest early flowering shrubs. Flowers white, fragrant, disposed in clusters. Flower's at the same time as the lilacs.

S. Bumalda. A handsome shrub with large clusters of cream-colored flowers.

\section{SYRINGA (Mock Orange)}

S. coronarius (Garland Mock Orange). This is the popular well-known variety; very sweet and one of the first to flower.

S. grandiflorus (Large-Flowered Syringa). Has very showy, large flowers, slightly fragrant; branches somewhat straggling.

S. foliis aureis (Golden-Ieaved Syringa). A rery pretty plant of medium size, of golden-yollow foliage. It keeps its color the entire season, and will be found valuable for creating pleasing aud striking contrasts with purple-leaved shrubs.

S. nanus (Dwarf Syringa). Of low labit; makes a dense, compact bush, rarely produces flowers; useful as a dwarf shrub.

S. Lemoinei erectus (Lemcine's Frect Syringa). A charming variety of upright growth ; flowers small, yellowish-white, fragrant, completely covering the plant.

s. Double Deutzia-Flowered. A fine double-flowering variety.

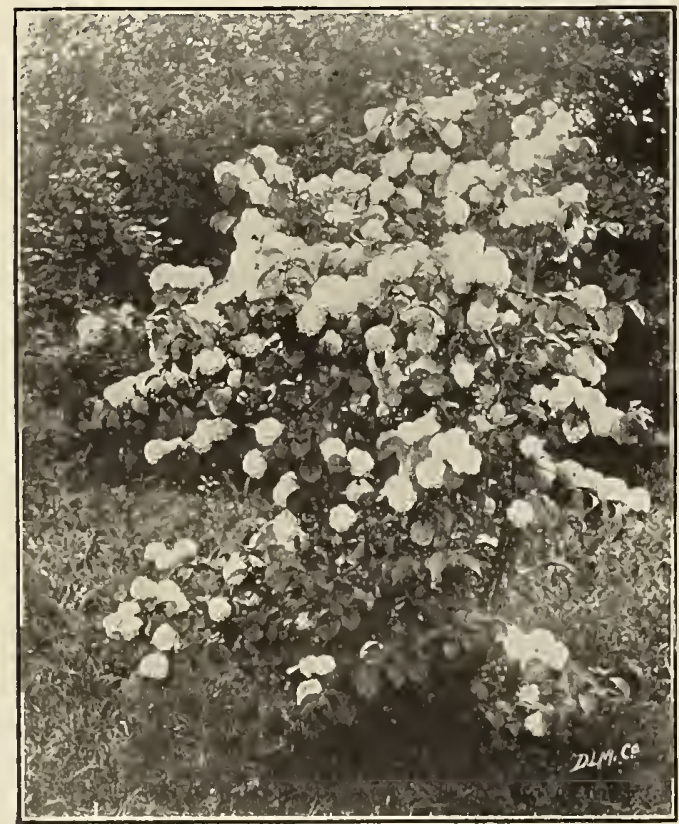

Viburnum

All Shrubs:

\section{SPIRAEA}

S. Fortune's Rose. Ilas large panicles of dnep rosy blossoms; grow's freely and blooms nearly all simmer: fine.

S. Anthony Waterer. I fine new dwa of spiral with dark crimson flowers. darker than sipira liumalda. One of the finest shrnbs of recent years. liach :3i.. doz. $\$ 3.50$.

Spiræa Van Houttei. W"ithout doubt the finest rariety in the collection. It the flowring seison in May and early June the plant is covered with a mass of liage, white flowers, presenting a beautiful appearance.

\section{TAMARIX}

These are rery beautiful shrubs, with small learos. somewhat like those of the Juniper, and delicate smill flowers in spikes. They are invaluable for planting by the seaside, where scarcely anything else will grow.

T. Africana. Handsome foliage, upright habit: flower's in May:

T. Chinensis. A vigorous, upright grower, witl delicate foliage of a lively green color; flowers rose-colored, in September.

T. Narbonne. Of straggling habit. Foliage glancous green; flowers in May before the leaves appear.

\section{VIBURNUM (Snowball)}

V. sterilis (Guelder Rose. Snowball Tree). A wellknown, favorite shrub, of large size, with globular clusters of pure white, sterile flowers the latter part of May.

V.plicatum (Japan Snowball), From North ("hina. Of moderate growth; handsome plicated leaves, globular heads of pure white neutral flowers early in Tune, It surpasses the common varict $r$ in several respects. Its habit is better, foliage much handsomer, flowers whiter and more delicate. One of the most valuable flowering shrubs. Each 75c, doz. \$7.50.

V.tomentosum. The single form of the beautiful Japan Snowball (V'iburnum plicatum); flower's pure white, borne along the branches in flat crmes, in the greatest profusion, early in June. Perfectly hards. vigorous, and free-blooming.

\section{WEIGELA}

W. nana foliis variegatis (Variegated-Leaved Dwarf Weigela). Of dwarf habit, and possessing clearly derfined, silvery variegated leaves; flowers nearly white. It stands the sun well, and is one of the best dwart ra riegated-leaved shrubs.

W. rosea (Rose-Colored Weigela). An elegant dirub, with fine rose-colored flowers, introduced from China by Mr. Fortune, and considered one of the finest plants he has discovered; of erect, compact growth; blossoms in June.

W. amabilis or splendens. Of robust liabit, linge foliage and pink flowers: blooms freely in the Autumn; distinct and beautiful.

W. Eva Rathke. I charming now Weigela, flowers brilliant crimson: a beautifnl, distinct, clear sharle.

W. Mme. Van Houttei. Clear carmine flowers. Slowr and handsome.

W. Conquete. Flowers deep pink, the largest of all Vieigelas.

w. Mont Blanc. Flowers very large, pure white. hardy and vigorous.

W. La Perle. Large flowers, creamy-white, edged witl; li.tit rose.

\section{XANTHOCERAS}

X. sorbifolia. From Central China. Forms a shruh or small tree, foliage resembling that of the Service Tree or Mountain Ash : flowers five-petaled. white, resldish copper-colored at base, disposed in racemes about eight inches long: flowers expand in April or May with the leaves. It is very floriferous, young plants flowering freely. Requires protection until establisled. Each 75c., doz. $\$ 7.50$.

Onr shrubs are all large, carefully selected plants, and can he sent by express only. purchaser paying express charces. Specinl prices given on quantities. 


\section{Tools and Requisites}

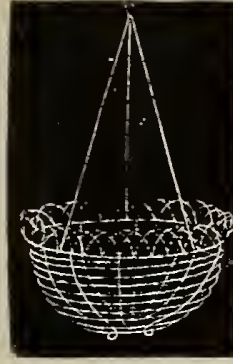

\section{WIRE HANGING} BASKETS

Each Doz.

10 in. $\cdots \frac{30}{30} \$ 2.75$

12 in.

14 in.

GALVANIZED WIRE HANGING BASKETS

10 in. Each $\$ 0.50 \quad$ Doz.

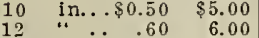

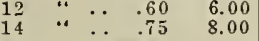

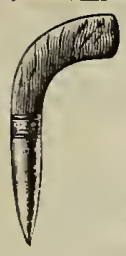

\section{GARDEN DIBBLE}

For transplanting cabbage, celery, tobacco, etc.

Small size $\ldots \ldots \ldots \ldots \ldots \$ 0.35$ Large

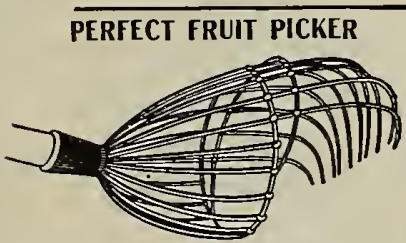

Galvanized wire. to fit any sized pole. $\begin{array}{r}\$ \\ 10\end{array}$

S. \& W. CO.'S FLOWER POT BRACKET

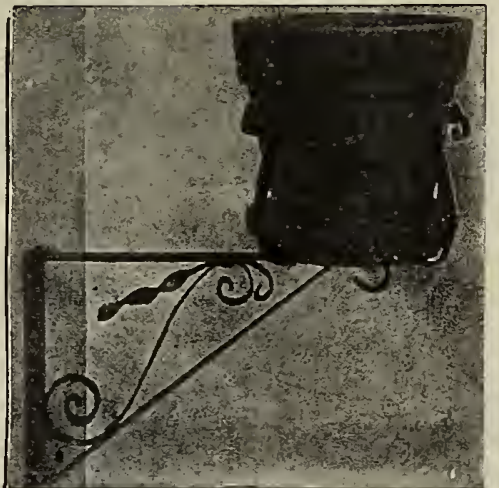

Made of steel, artistic in design and finish. Finished black, very strong and durable. Flower-pots and Saucers are absolutely secured by the spring clasp. Especially adapted to hold plain pots and saucers.

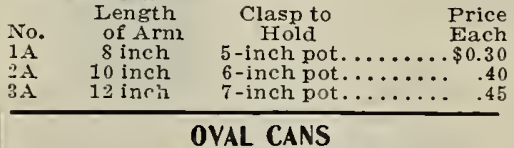

Heavy Galvanized

Each

qt. $\ldots \ldots \ldots \ldots \ldots \ldots \ldots \ldots \ldots \ldots \ldots 2.50$

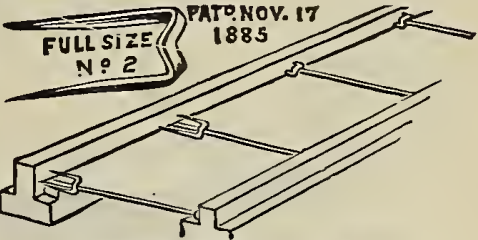

GLAZING POINTS Van Reypezs.

Per $1.000 \ldots . \$ 0.65 \quad 5.000 \quad \ldots \ldots \$ 3.00$

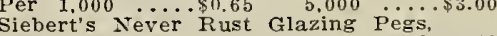
Model Points, lb

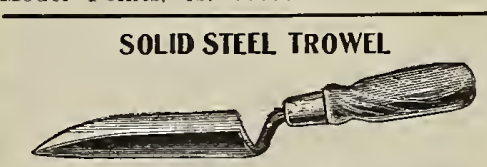

Hand forged, oil tempered, ferrule andle, and a splendid trowel for gen-

6 in. .... \$0.35 7 in. $\$ 0.40$ MAYNARD TROWEL

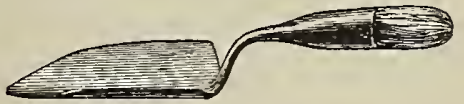

Solid steel trowel, the very best trowel made, socket shank, highly polished.

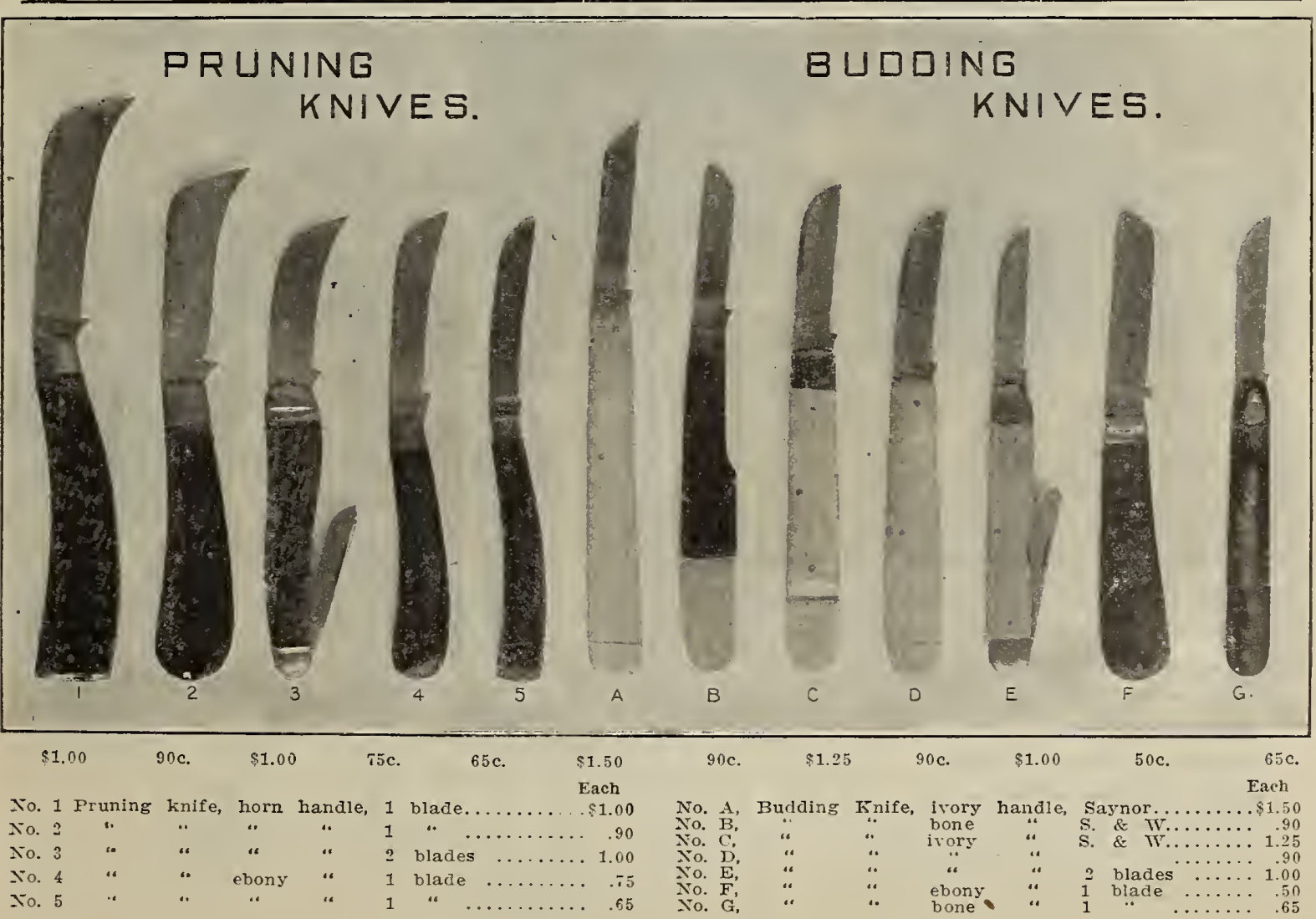




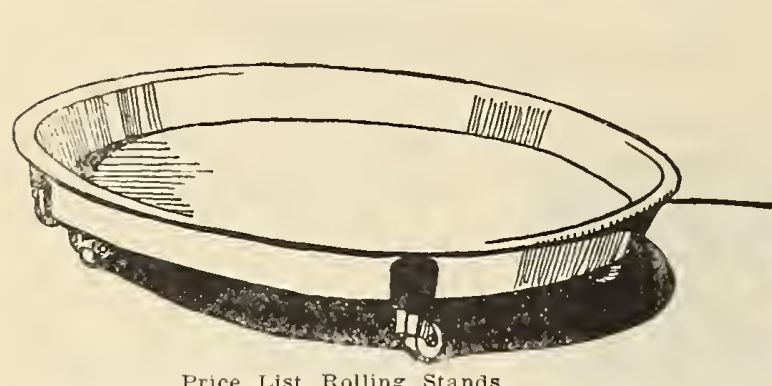

Price List Rolling Stands
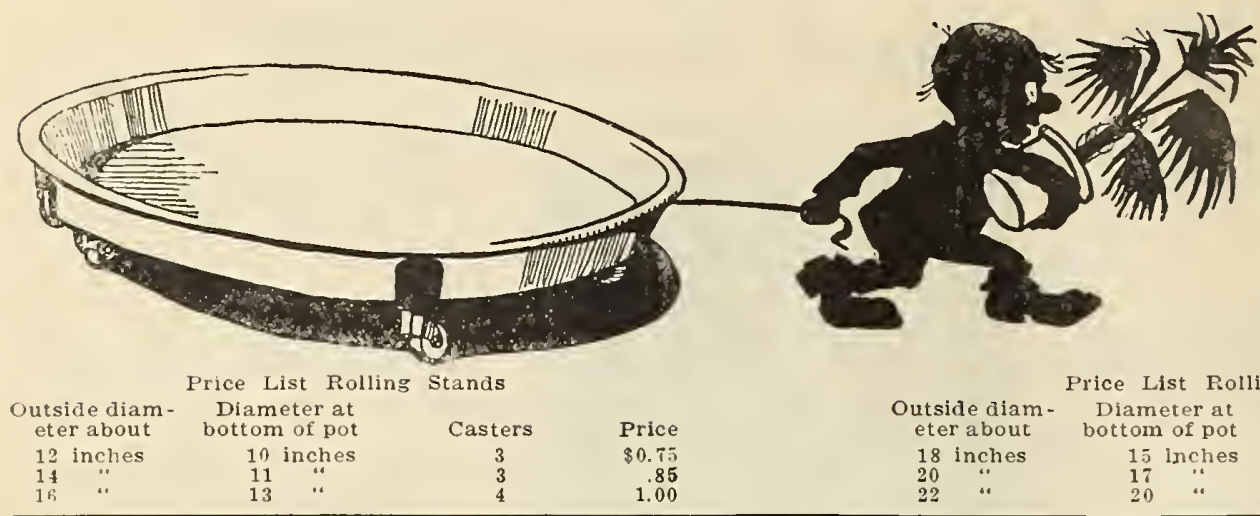

ROLLING STANDS FOR HEAYY PLANTS

platforms are Indurated Fiber Ware. Will not soak or rust. Casters harc ball-bearings. Evcry heavy p!ant solu needs one to save carpets and floors, and to enable carpets and floors to be readily cleaned.

\section{FLOWER POT SAUCERS (Waterproof)}

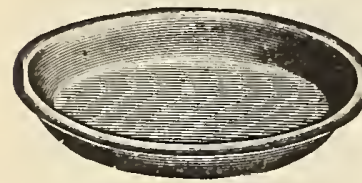

If you have ever been angoyed with ordinary, flowerpot saucers absorbing moisture and dispensing it imperceptibly until the article it sat on was ruined you will then fully appreciate the value of these new indurated fuer-ware saucers. They do not absorb moisture and are not easily broken. Color. terra cotta brown.

\begin{tabular}{|c|c|c|c|c|c|}
\hline & Each & Doz. & & Each & Doz. \\
\hline $4-i \pi c h$ & $\ldots \ldots \ldots \$ 0.10$ & $\$ 1.00$ & 10 -inch &.$\$ 0.20$ & $\$ 2.00$ \\
\hline ; " & $\ldots \ldots \ldots$ & 1.30 & $11 \quad "$ & . $\quad .21$ & \\
\hline$"$ & $\ldots \ldots \ldots$ & 1.50 & 12 & 23 & 2.30 \\
\hline & 16 & 1. 601 & 13 & 24 & 2.40 \\
\hline .. & $\cdots \cdots$ & $\begin{array}{l}1.10 \\
1.80\end{array}$ & & & \\
\hline
\end{tabular}

\section{HOTBED MATS}

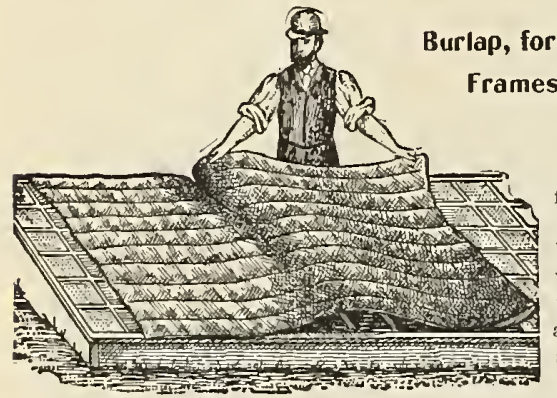

These are $6 \times 6$ feet. square. made of strong burlap bagging w a $r m$ i y lined with waste wool and cotton, which are quilted in to hold position.

\begin{tabular}{|c|c|c|c|c|}
\hline & & & Each & Doz. \\
\hline No. & $40 \times 76$ & Burlap & $\$ 1.00$ & $\$ 10.00$ \\
\hline No. & $76 \times 76$ & Burlap & .1 .40 & 15.00 \\
\hline No. 2 . & $40 \times 76$ & Duck and Burlap & 1.25 & 12.00 \\
\hline No. 2 , & $76 \times 76$ & Duck and Burla'p & 2.00 & 20.00 \\
\hline No. 3 , & $40 \times 76$ & Duck both sides & 1.50 & 16.00 \\
\hline 3 & $76 \times 76$ & Duck both sides & 2.50 & \\
\hline
\end{tabular}

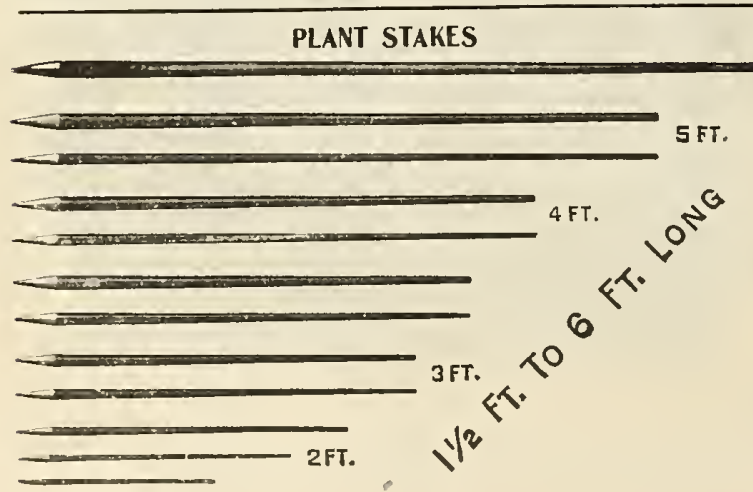

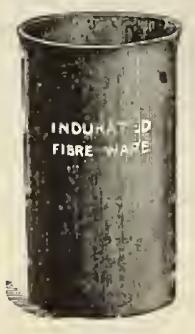

Price List Rolling Stands

Outside diam - Diameter at $\begin{array}{rr}\text { eter about bottom of pot } \\ 18 \text { inches } & 15 \text { lnches }\end{array}$

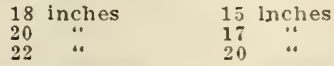

Caster

PRICE-LIST OF FLORISTS' VASES

For Displaying Cut Flowers Diameter Depth Order by Plain, Inch, inside Inch, inside No. perdoz.

\begin{tabular}{lccr}
8 & 13 & 0 & $\$ 6.01$ \\
$51 / 2$ & 10 & 1 & 5.511 \\
$41 / 2$ & 9 & 2 & 4.79 \\
4 & 6 & 3 & 3.75 \\
3 & $41 / 2$ & 4 & 3.11 \\
9 & 22 & 00 & 24.100 \\
$51 / 2$ & 18 & 11 & 7.50 \\
$41 / 2$ & 15 & 22 & 6.00 \\
4 & 12 & 33 & 5.51 \\
3 & 9 & 44 & 5.00 \\
9 & 29 & 000 & 30.011 \\
\hline
\end{tabular}

LABELS, Wooden, Pot and Garden
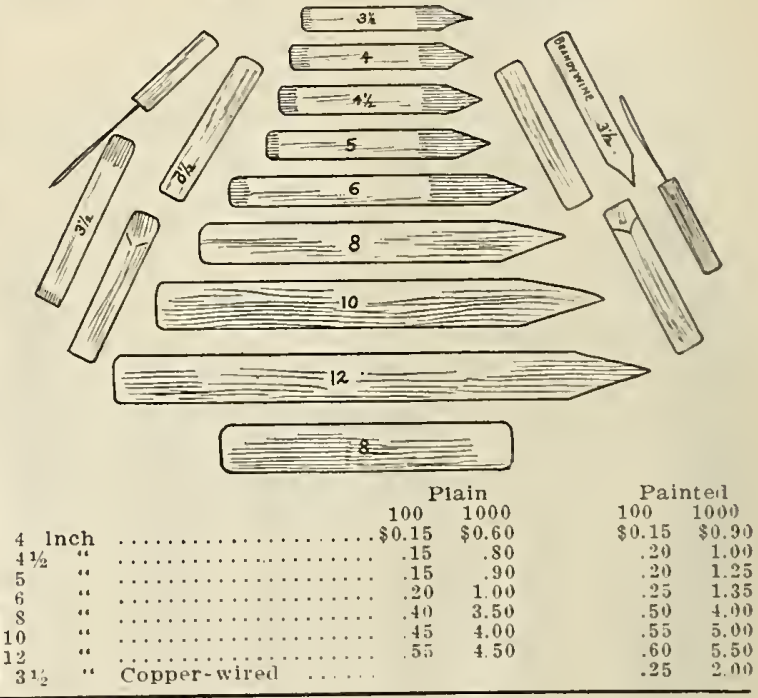

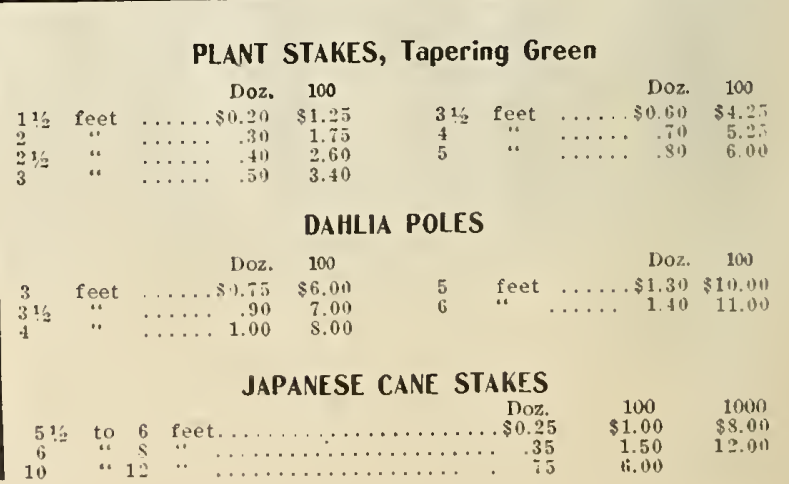




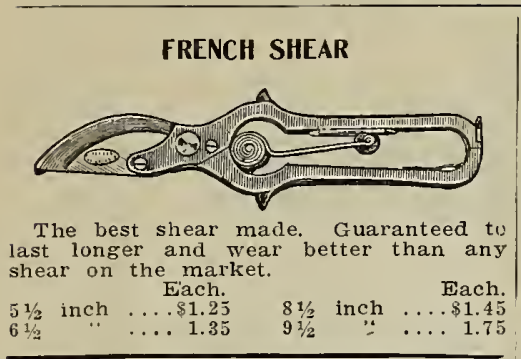

Wiss Solid Steel Pruning Shear

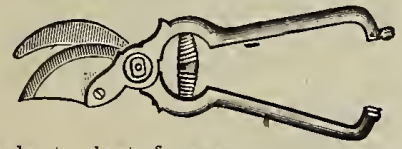

Nade to last forever.

$109-9$ inches, each........... $\$ 2.00$ $110-10$

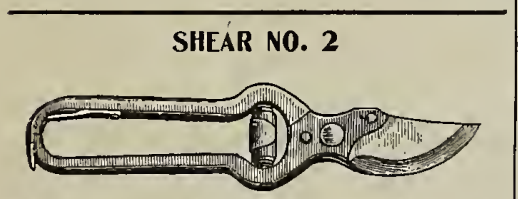

Steel blades, malleable handles, 8 inches. Each. $\$ 0.50$.
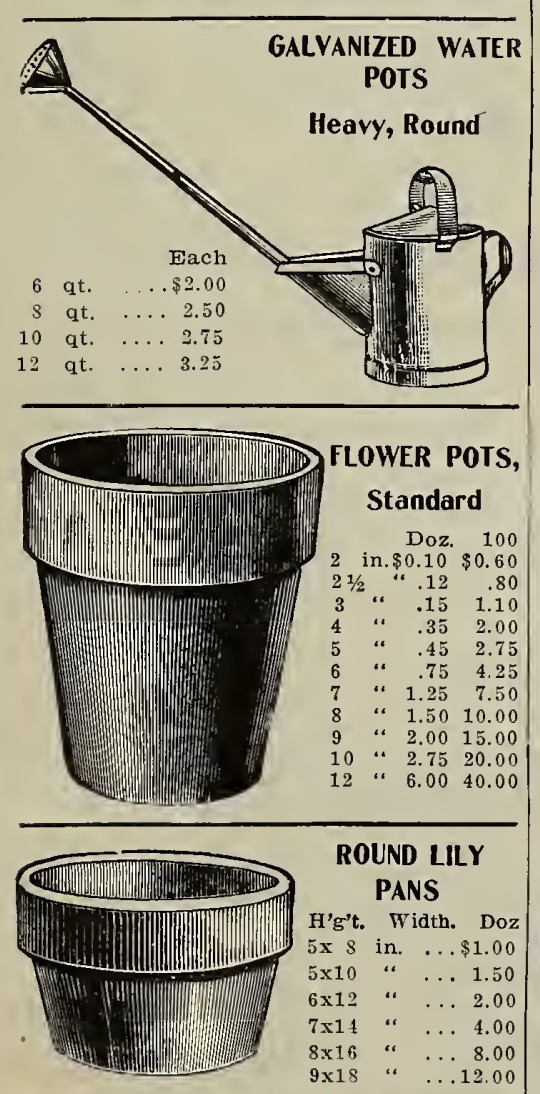

\section{ROUND LILY \\ PANS}

H'g't. Width. Doz $5 \mathrm{x} \&$ in. $\ldots \$ 1.00$ $5 \times 10 \quad$ “ $\ldots 1.50$ $6 \times 12 \quad \cdots \quad \ldots 2.00$ $7 \times 14 \quad$ “ $\ldots 4.00$ $8 \times 16$ “ $\ldots 8.00$ $9 \times 18 \quad$ " $\ldots 12.00$

\section{PAPER}

Wax $\ldots \ldots 24 \times 36$, ream $\ldots \ldots \ldots \$ 3.00$ Tissue $\cdots \ldots \ldots 18 \times 24, \quad " \ldots \ldots \ldots \ldots 2.00$

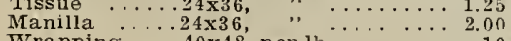

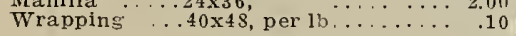

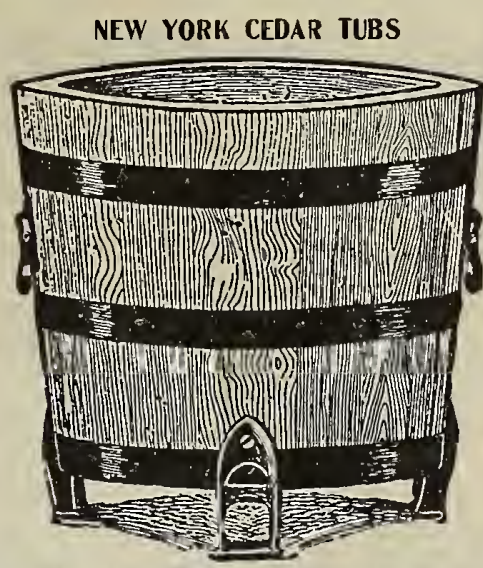

These tubs are made of the very choicest, seasoned cedar, linghly finished with black hoops, cypress tubs. They are very strong and durable, No. $\quad$ Diameter $\quad \begin{gathered}\text { Height } \quad \text { Price } \\ 1 \ldots \ldots \ldots \ldots \\ 2 \ldots\end{gathered}$

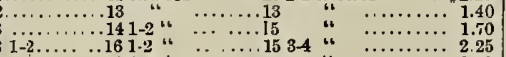

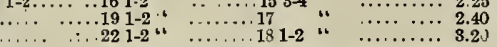
CEDAR TREE TUBS

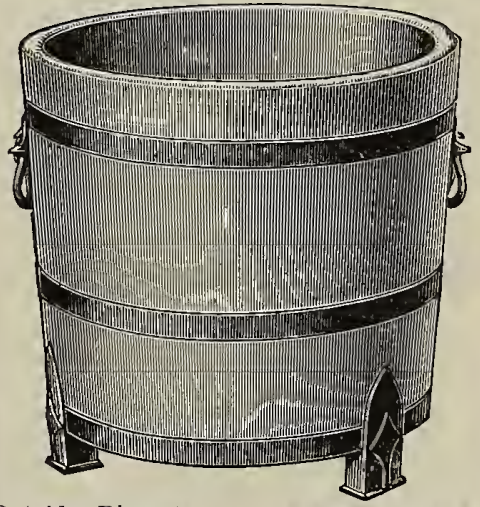

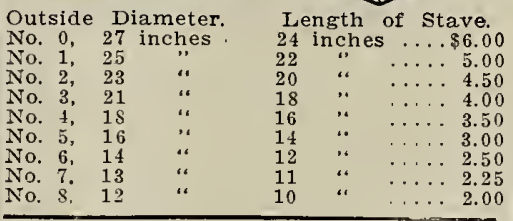

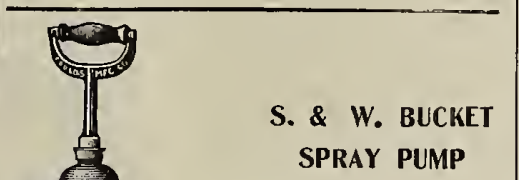
$20 \times 7 \times 4$
$28 \times 8 \times 5$
$30 \times 12 \times 6$
$36 \times 14 \times 8$
$48 \times 14 \times 8$

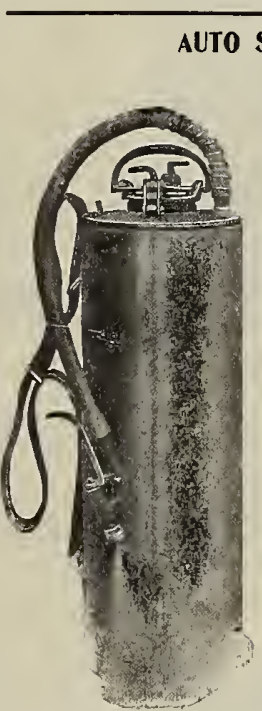

AUTO SPRAY

C o n ve $n$ i ent durable, efficient Our pate n te leader of spray small uses. Will do better work and do it easiel than any other similar article Useful with Bordeaux a $n$ all solutions, also in applying paints or white wash. Holds four gallons. Illustration shows our new "Auto-Pop" at a chment the efficiency by saving half the sol u tion and labor. Our "Anti-Choke" Nozzle, cleaned at every operation of "Auto-Pop' can never clog. galvanized stee or brass. Higl gr a d e hos e

Heavy self-contained pump, all brass. Nipple connections, nozzle, etc., turned from solid brass rod with full threads. Castings for handle, etc., all malleable. No continuous pumping as in the case of the Knapsack Sprayer-no continuous pumping or slopping as in the case of the bucket pump. A few strokes of plunger compresses enough air to cover a quarter acre of potatoes or similar crop. The operator simply holds the nozzle. Also used for spraying disinfec tants. A practical machine for potatoes, tobacco, small fruits, vineyards, poultry houses, greenhouses, etc. Extension pipes useful for spraying tall trees. Detailed descriptive circular on request.

"Auto-Spray," No, 1. Brass Tank, with Stop Cock ............. \$6. "Auto-Spray," No, "1, Brass Tank,

"Auto-Spray," No. 1. Galvanized Tank, with Stop Cock ....... 4.50 "Auto-Spray," "No. 1, Galvanized
Tank, with "Auto-Pop" ...... 5.50 "Auto-Pop," supplied separately... 1.50 


\section{FERTILIZERS}

\section{Clay's Celebrated Fertilizer}

Prices. in bags, 1 cwt. (112 lbs.) $\$ 5.00$, 1/2 crt. (5i lbs.) $\$ 4.00,1 / 4$ cwt. (28 lbs.) $\$ 2.25$, 1/4 cwt. (14 lbs.) $\$ 1.25$.

\section{Quick-Acting Bone Flour .}

This bone is ground as fine as it is possible to have it. and where a high grade bone is wanted for immeliate results we recommend its use. 5 lbs. 3.5c., $10 \mathrm{lbs}$. b0c., 25 lbs. $\$ 1.25,50$ lbs. $\$ 2.00,100$ lbs. $\$ 3.50$, ton $\$ 50$.

\section{General Use Bone}

This bone is ground to about pin-hear size, with a fair percentage of flour bonc, and where a high grade bone for immediate and continuous use is manted, mould advise using this grade. 5 lbs. 25 c.. 10 lbs. 40c., $25 \mathrm{lbs}$. 7.jc. 50 lbs. $\$ 1.40,100$ lbs, $\$ 2.50$, ton $\$ 40.00$.

\section{Pure Pulverized Sheep Manure}

A pure, natural and nutritious mauure. Immediate aud lasting in effect. Excellent for mixing with the soil for greenhouse plants. In the vegetable garden it promotes a rapid, steady growth until maturity. It makes a rich Liquid Manure.

Quantity Required. For zarlen and field crops, 1 to 2 tons per acre: one-half before plowing, the balance before harrowing. For top-dressing grass, use 1 ton per acre. applied in Fall or early Spring. 100-lb. bag $\$ 2.00$, ton of 2000 lbs. $\$ 30.00$. In packages of $2 \mathrm{lbs}$. $15 \mathrm{c} ., 5 \mathrm{lbs}$. $25 \mathrm{c} ., 10$ lbs. 40 c., car, 15 tons, $\$ 22.50$ per ton.
Thomson's Vine, Plant and Vegetable Manure

$2 \$$ lbs. $\$ 1.75$, 56 lbs. \$3.50. 112 lbs. $\$ 6.75$.

\section{Thomson's Special Chrysanthemum} and Top Dressing Manure

An excellent stimulant for top-dressin: rhrrsanthemums and all flowering plants. $T-1 b$. bag $\$ 1.50,13-1 b$. lag $\$ 2.50$, 2\$-1b. bag $\$ 4.00$, 56-lb. bag $\$ 7.00$.

\section{Ashes. \\ Canada Hard Wood}

Quantity Required. Ipply 1 to 2 tons per acle. as one heary application will help much more than the same quantity would applied in fractions. Bbl. of about $200 \mathrm{lbs}$. $\$ 3.00$, ton of 2000 lbs., in bbls. $\$ 22.00$, car, $\$ 20.00$ per ton.

\section{Nitrate of Soda}

Quantity Required. Being extremely soluble, it is usually applied after the plants are above ground, 100 to $500 \mathrm{lbs}$. per acre. 5 -lb. package $40 \mathrm{c}$. 10-lb. package T0c., 25-lb. bag $\$ 1.50$. 50-lb. bag \$2.50, 100-lb. bag \$4.50.

\section{"Bonora" "Nature's Plant Food"}

5 lbs. making 140 gallons. \$2.50. 1/4-1b. package 2-5c. 1-lb. package $50 \mathrm{c}$.

Circular and further information on application.

\section{REMEDIES FOR INSECTS AND FUNGUS}

\section{Fir Tree Oil}

The hest Insecticide in the market for greenhouse aud house plants; it frees plants of nearly all insects to which they are subject, and for the following it has no superior: Mealy bug, scale, red spider, aplis (black and green), thrips, blight, worms and slugs. and is also a valuable remedy for animal parasites and insects. $1 / 2$-pt. tin 40c., pt. Tic., qt. \$1.25, 1/2 gal. \$2.25, wal. \$4.00. Directions for use ou each can.

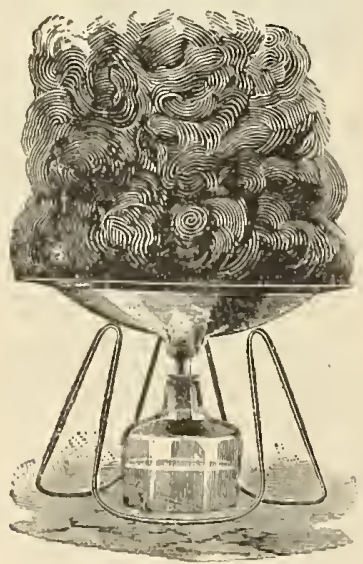

\section{Nicoticide}

For killing all kinds of insects on plants in greeuhonses and frames. Tlise most easy, safe aud effective metliod of fumiga ting greenhouses and frame ever introduced. $4-0 \%$ can $70 \%$. 1\%-pt. can \$1.2.) 1-pt. can \$2.ко. Fumisators for using above. complete, each J0c.

\section{Nikoteen}

Pt. $\$ 1.50$.

\section{Whale Oil Soap}

Ih. 20c.. ј lbs. नic.
To-bak-ine Products

Will positively kill green and black fly. thrips, mealy bug, red spider and other insects on flowers, plants. trees, etc.

To-bak-ine Fumigating Paper. For quick and effective fumigation. Box 60c.; by mail $70 \mathrm{c}$.

To-bak-ine Liquid. For spraying and raporizing. 1/4 pt. 60c., 1/2 pt. $\$ 1.10$, pt. $\$ 2.00$. gal. \$1J.(r).

\section{Flowers of Sulphur}

For mildew. I.b. 10c., 5 lbs, $40 \mathrm{c} ., 10 \mathrm{lbs}$. 60c.. 100 lbs. $\$ 5.00$.

\section{Grape Dust}

For mold mildew or rust mites, either in greenlinuse or ojen air. $5 \mathrm{lbs}$. 40c.

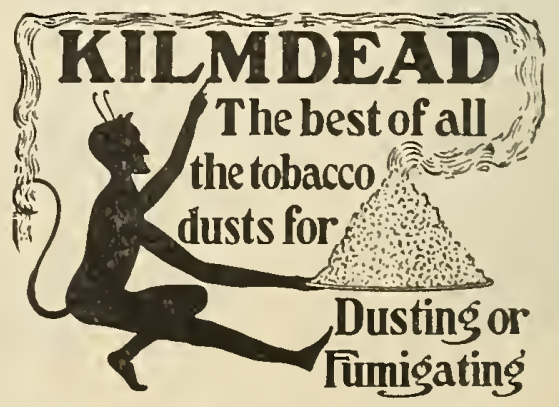

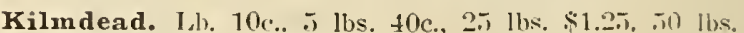
$\$ 2.25,100$ lbs, $\$ 4.00$.

Nikoteen Aphis Punk. By mail isc. per box of 12 rolls. 


\section{SELECTED

Reliable Red Winter Wheat is a very early variety, ripening before rust, blight, or chinch bugs or other insect pests appear in the fields. It yields from 30 to 40 tushels an acre and we have had reports of even larger yields on good soil. It is a bearded variety; the kernels are red with a very thin husk. are hard and flinty and very rich in gluten. It is stiff-strawed and will stand $u p$ in wind and rain which would lodge other varieties very badly. Peck 75c., bushel $\$ 2.75,10$ bushels $\$ 25.00$.

Klondike Wheat. Of all the Wheats introduced here during the past twelve or fifteen years, the one which seems to have created the greatest sensation among the farmers on account of its hardiness, productiveness and fine quality, is the Klondilie which was introduced a few years ago and has been making very rapid strides ever since. It has yielded in quite a number of instances, from 45 to 47 bushels per acre. One grower claims to have had over 45 bushels per acre for three consecutive years and we shall not be surprised to see the record broken this year for we have some crops which certainly look as though they would yield 50 bushels per acre. This is a bald, white Tinter Wheat which "stools" to a remarkable extent, producing a heavy yield notwithstanding the fact that the heads are not very large nor very long, enabling the straw to stand up much better than would be possible in the case of larger nead. The grain is large, plump and of a creamy white color. Millers are very mush pleased with it but have never been able to get as much as they wanted of it because the farmers have generally sold their crops for seed rather than for grinding. Peck $\$ 1.00$, bushel $\$ 3.00,10$ bushels $\$ 27.50$.

Red Cross (Beardless). An enormous yielder, and the best red wheat for all locations. Quart $20 \mathrm{c} .$, by mail $35 \mathrm{c}$; peck $75 \mathrm{c}$, , bushel $\$ 2.75,10$ bushels $\$ 25.00$.

Harvest Queen (Beardless). Considered one of the best for milling, early, hardy and very productive. Quart 20c., by mail 35c.; peck 65c., bushel $\$ 2.25$, 10 bushels $\$ 20.00$.

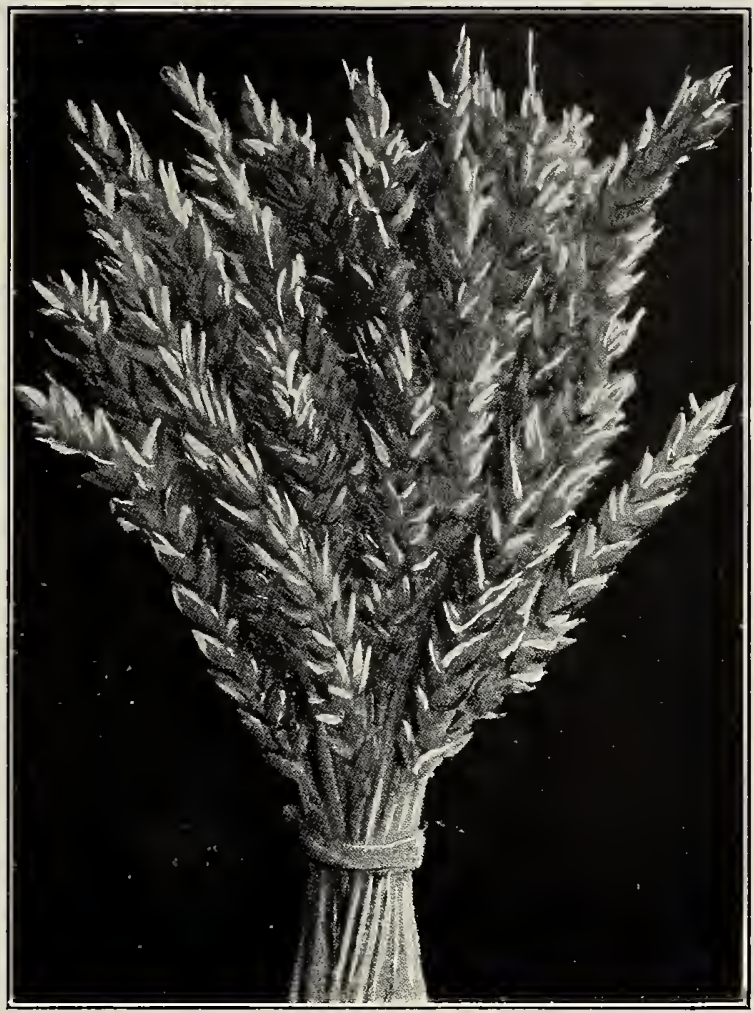

\section{Mammoth White Winter Rye}

Noted wherever tried for its productiveness both in grain and straw, the excellent quality of bread made from the flour, and its ability to yield heavy crops with but little or no manure. Quart $20 \mathrm{c}$., by nail $35 \mathrm{c}$; ; peck $65 \mathrm{c}$, bushel $\$ 2.15,10$ bushels or over $\$ 2.00$ per bushel.

\begin{tabular}{|c|c|c|c|c|c|c|}
\hline EED & $\begin{array}{l}\text { Weight } \\
\text { per bush } \\
\text { lbs }\end{array}$ & & & $\begin{array}{l}\text { Prie } \\
\text { bush } \\
\text { deliv }\end{array}$ & $\begin{array}{l}\text { per } \\
\text { nut } \\
\text { ered }\end{array}$ & $\begin{array}{l}\text { Price per } \\
1001 \text { be. not } \\
\text { delivesed }\end{array}$ \\
\hline ce seed. & . 14 & $\$ 0$ & 20 & $\$ 2$ & 25 & $\$ 14 \quad 00$ \\
\hline $\begin{array}{l}\text { Clean seed, free from chaff. } \\
\text { Grass (Poa Pratensis). Well-k }\end{array}$ & 32 & & 30 & 8 & 00 & 2300 \\
\hline $\begin{array}{l}\text { e country } \ldots \ldots \ldots \ldots \ldots \\
\text { A valuable pasture grass }\end{array}$ & 14 & & 25 & 2 & 50 & 1600 \\
\hline $\begin{array}{l}\text { ted for growing in shady } \\
\text { riety well-known and highly }\end{array}$ & 14 & & 35 & 4 & 50 & $\begin{array}{ll}30 & 0.0\end{array}$ \\
\hline dIIIS & 45 & & 15 & 3 & 50 & 700 \\
\hline
\end{tabular}

\section{CLOVER SEED}

Red Clover Medium (Trifolium Pratense). Medium clover. The leading rariety of clover for pastures or meadows. Very finest quality .......... White Dutch Clover (Trifolium Repens). The best variety for lawns, as it
forms a close herbage and remains green throughout the season ......

Alfalfa, or Lucerne (Medicago Sativa). One of the best varieties, succeeding especially in the South and West, and bearing heavy crops of forage.

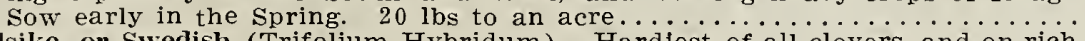

Alsike, or Swedish (Trifolium Hybridum). Hardiest of all clovers, and on rich, moist soils yields an enormous quantity of hay or pasturage. Lasts many

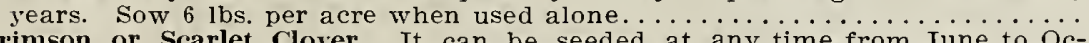

Crimson or Scarlet Clover. It can be seeded at any time from June to OcSpring pasture, blooming the latter part of April or May, and for feeding as hay should be cut just before coming into full bloom. Sow Crimson Clover at the last working of all crops like Beans, Corn, Melons, Cucumbers,

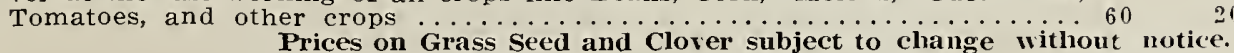





\section{The Effect}

of an application is visible within a very few hours; the weeds blacken and die; the grass may become pale, but it quickly recovers its color, and young growths appear on the bare spots previously occupied by the weeds.

"Climax Lawn Sand" combined with dry heat absorbs promptly every particle of sap contained in the foliage of a plant to which it can stick long enough and thereby kills it; on the other hand, just as soon as it combines with moisture and is carned to the roots of grasses the destructive qualities changes into a very productive one, as it acts as a most powerful fertilizer and produces the most vivid green on grass that has ever been seen. For this reason it is essential that should the weather be very hot and dry, the lawn should be thoroughly watered on the expiration of 48 hours after the application.

\section{Fertilizing Qualities}

Where "Climax Lawn Sand" is used no other manure is required. It acts as one of the most powerful fertilizers for grasses if applied as a top dressing in the early spring, and produces a green which cannot be equalled with any other chemical. Many of our friends who have used "Climax Lawn Sand" as a destroyer of weeds solely, were so pleased with its fertilizing qualities that they desire to use it in future as a manure in preference to well known preparations. For top dressing $1 / 4$ ton is required per acre.

\section{QUANTITY REQUIRED AS A DESTROYER}

\begin{tabular}{|c|c|c|c|c|c|c|c|c|}
\hline Can & of & 3 & 1-2 lbs. & will & dress & s 150 & square & fee \\
\hline “ & " & 7 & 14 & $" 1$ & $" 1$ & 250 & ". & 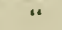 \\
\hline " & $\because$ & 14 & ". & “. & “. & 500 & .. & \\
\hline ". & “ & 28 & " & •. & ". 1 & 1000 & “ & \\
\hline$" 4$ & $"$ & 56 & .. & “. & . 2 & 2000 & “ & \\
\hline "6 & ." & 112 & “. & .. & " 4 & 4000 & " & 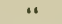 \\
\hline
\end{tabular}

If the weeds are but few in a space, the above quantities will cover correspondingly larger areas. "Climax Lawn Sand" is no more an unknown quality but has been extensively tried with splendid success all over the United States and Canada.

\section{TESTIMONIALS}

Gentlemen :

Southport, Jų̧e 8, 1908.

I have great pleasure in testifying to the satisfactory results obtained from the use of your "Climax Lawn Sand," in a plot of grass in our park, which was heavily covered with all kinds of weeds. This plot was dressed with your "Lawn Sand" and in a matter of three weeks, a most marvelous result was shown: Not a single weed was to be found on the plot, only a rich dark grass, of quite a different green, to that on parts which had not been dressed with the preparation, showing the Sand to be also a strong fertilizer. The plot in question is on public view and has been since the experiment was started, so that I can safely recommend the "Climax Lawn Sand" as a thorough Weed Destroyer and Fertilizer and I wish you all the success with it that it deserves. Yours respectfully,

Signed, WALLACE SHUTTLEWORTH.

We have used up the keg of "Lawn Sand" and it seems to be doing the work well. Kindly send me immediately two more kegs.

Mrs. F. NORTON BIGGS,

Hinsdale, Ills.

Please send me a $56 \mathrm{lb}$. keg of "Climax Lawn Sand." The sample I have used has proven very successful; also the "Climax Weed Killer" on roadway and pavement.

MARY CHENEY,

So. Manchester, Conn.

In regard to the "Climax Lawn Sand," which the writer tried last year, we wish to say that it gives extremely satisfactory results. On a portion of $m y$ lawn, in front of the porch, I had considerable plantain leaves, which, after an application of "Lawn Sand, "disappeared entirely and did not seem to appear again this year. It is highly satisfactory.

Truly yours,

PAUL F. RICHTER,

Philadelphia, $\mathrm{Pa}$.

July 8,1908 .

I have used the sample of "Climax Lawn Sand" you sent me some time ago and it seems to do the work very well. I want to try a $112 \mathrm{lb}$. wooden keg and you will please ship the same by fast freight. Truly yours,

F. L. COLBY,

Detroit, Mich. 
Recently I ordered from you a small package of "Climax Lawn Sand" and found it to work very well. I would like to get some more of it.

$$
\text { H. E. EYMAN, }
$$

86 Chestnut St., Mutley, N. J.

Gentemen s

Kindly send me a $56 \mathrm{lb}$, keg of "Climax Lawn Sand." Address as before to Worcester, via B. \& A. I have tried it and find it does just what you claim, although I must confess I didn't take much stock in it at first. Enclosed is my check to bal. Yours sincerely,

H. H. MERRIAM,

Worcetter, Mass.

Dear Sirs:-

Please send me a $56 \mathrm{lb}$. keg of your "Climax Lawn Sand." 1 find its action on weeds wonderful. Mrs. FRANK HINCKLEY,

Bangor, Maine.

August 13, 1908.

Dear Sirs:-I have bought several kegs of your "Lawn Sand," and can highly recommend it, both as a Fertilizer and Weed Killer.

$$
\text { Yours truly, }
$$

O. DANNESBOE.

I have been trying your "Lawn Sand" on a small space of very weedy lawn and it has killed off all the weeds.

\section{Mrs. E. A. RUSSELL.}

Lake Forest, III.

Please send me at the address below twenty-eight pounds of "Climax Lawn Sand" at your earliest convenience. I have tried the small sample which you sent me a short time since, and it seems to work fairly well.

Yours truly,

WM. NOTTINGHAM,

Syracuse, N. Y.

Having found "Climax Lawn Sand" quite successful on trial, I enclose $\$ 5.00$ and would like $56 \mathrm{lbs}$, sent to me. Truly yours,

Mrs. JOHN HAY,

Newbury, N. H.

I have received the sample of "Climax Lawn Sand" and have given it as much of a trial as I conveniendly could wih such a small quantity. I think it is effective.

HENRY A. SHERWIN.

Cleveland, Ohio.

\section{DANDELIONS DESTROYED}

Root and Branch, on Lawns, Drives, Paths, Roads etc. By "CLIMAX WEED KILLER"

A single application will destroy it and prevent its reappearance forever.

By its use weeding is dispensed with, and the surface remains in a firm and bright condition.

POWDER FORM: Packed in airtight tins. Mixes readily in cold water, without heat or fumes, convenient to store and handle. It will keep for an indefinite period.

\section{DIRECTION FOR USE}

Dissolve the powder to a liquid (Tin No. 1 is enough to make 25 gallons) and then employ the

\section{"Wikeham Weed Eradicator"}

a simple machine, as per cut enclosed, to do the work. It is a tubular staff 36 in. long, fitted with a self-acting valve, so arranged, that when filled with the "Climax Weed Killer" by simply pressing the point into the plant, enough liquid is infected into the tissues to destroy it.

It is made of brass, especially hardened and bronzed, fitted with a perfectly tight Screw Cap. When not in use the point is protected by a ferule which can be taken off when desired.

It is the simplest and most effective instrument ever made.

You pierce the point of the Eradicator into the very crown and root of the Dandelion and the root is forever destroyed without the least injury to the surrounding grasses or plants.

No bending, no scratching, no weight and no digging. A pastime for the young and old as well.

COST: "Climax Weed Killer" is put up in Tins of 2 sizes.

Tin No. I (enough to make 25 gallons of liquid) - $\$ 1.50$

" "2 (" " " 100 ". " " $\quad 3.00$

Wikeham Weed Eradicator (compiete) $\quad 4.00$ 
PRICES OF

\section{"Climax Lawn Sand"}

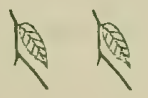

$31-2$ lbs. Tin can - - $\$ 060$

7 lbs. Tin can - - - 100

14 lbs. Tin can - - - 175

28 lbs. Wooden keg - 300

56 lbs. Wooden keg - 500

112 lbs. Wooden keg - 800

Purchaser paying transit

\section{Climax Lawn Sand}

KILLS EVERY WEED that grows on Grass Lawns, and also Improves the Grass.

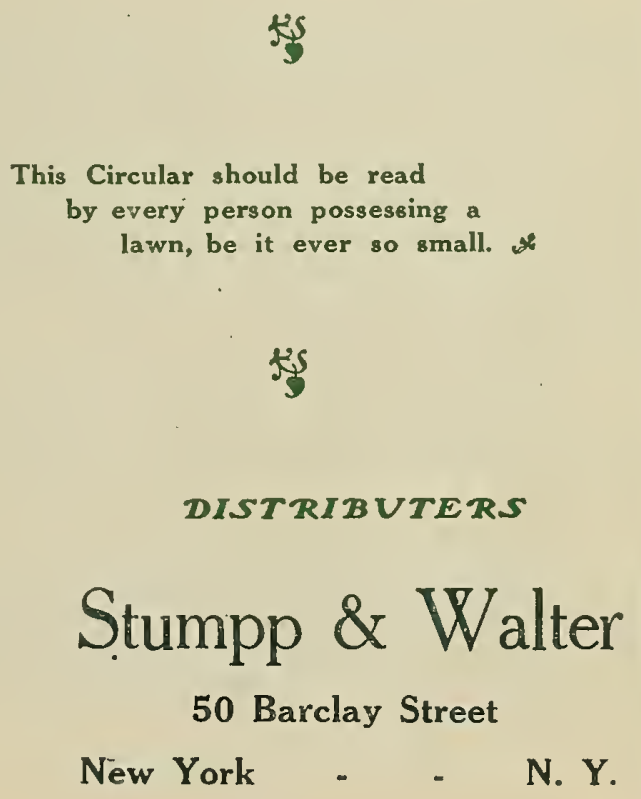




\section{What is}

\section{"Climax Lawn Sand"?}

A unique combination of carefully dried and finely ground chemicals, which if sprinkled over the grass possesses the remarkable property of destroying Moss, Chickweed, Plantains, Dandelions and all other weeds on Lawns, Tennis Courts, Golf Greens etc., at the same time promoting the growth of the finer grasses to such an extent that the spaces previously occupied by the disfiguring weeds are quickly covered by a perfect sward of fine closegrowing grass, of good color, which will retain its freshness under adverse conditions of continuous use and drought. Over five thousand American users during the past season have proved to their entire satisfaction that it is so.

When this article was first offered to the American Public we received hundreds of inquiries. How is it possible for any preparation to destroy weeds and not the grass? The explanation is as follows:

The chemicals used in "Climax Lawn Sand" are of such a nature, that they will readily destroy any plant to which they can adhere: Weeds as a rule have broad hairy leaves or grow in mattings so that powder can easily remain on the plants for several hours, while the grasses are smooth and finebladed and do not accept the sand as adherence.

\section{When to Apply}

SEASON: "Climax Lawn Sand" may be applied any time during the growing season of the year, namely from beginning of April to the end of October.

CONDITIONS OF THE LAWN: The law'n must be absolutely diy; by that is meant that no rain or dew must be visible on the grass.

TIME OF DAY: Ten to twelve a. $m$. during the months of April, May and October, nine to twelve a. m. during June, July, August and September.

WEATHER: Only apply in fine weather when the temperature is fairly high and when no rain appears likely for a day or two. This is most important.

\section{How to Apply}

For shallow rooted close-cropped weeds such as Moss, Chickweeds or Daisies sprinkle "Climax Lawn Sand" all over each patch, so as to lightly cover them with slight dusting, distributing evenly about five ounces for every square yard. Gauge the quantity according to the number of weeds. Repeat the application if any escape the first dressing. For all flatleaved, shallow rooting weeds such as Plantains, Thistles etc., a larger quantity is required and we recommend that a small teaspoonful should be placed on the crown of each plant.

DANDELIONS and other deep rooting plants with tap roots are the most plentiful and also the most troublesome to deal with. We recommend roughly slicing off the crown and putting a large teaspoonful on the wound. The plant will break out again lower down when this treatment should be repeated. The top root will then decay and the dandelion will never trouble you again. Only in rare instances is a third application necessary.

"Please note our offer of "Climax Weed Killer" for prompt and effective destruction of Dandelions." 


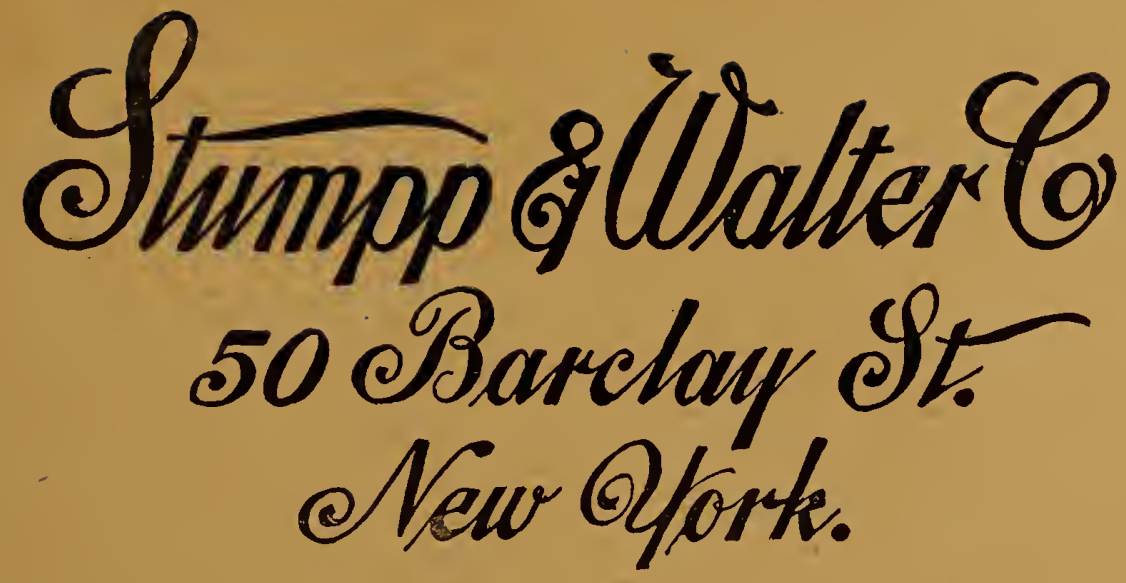






\section{FALL 1909}

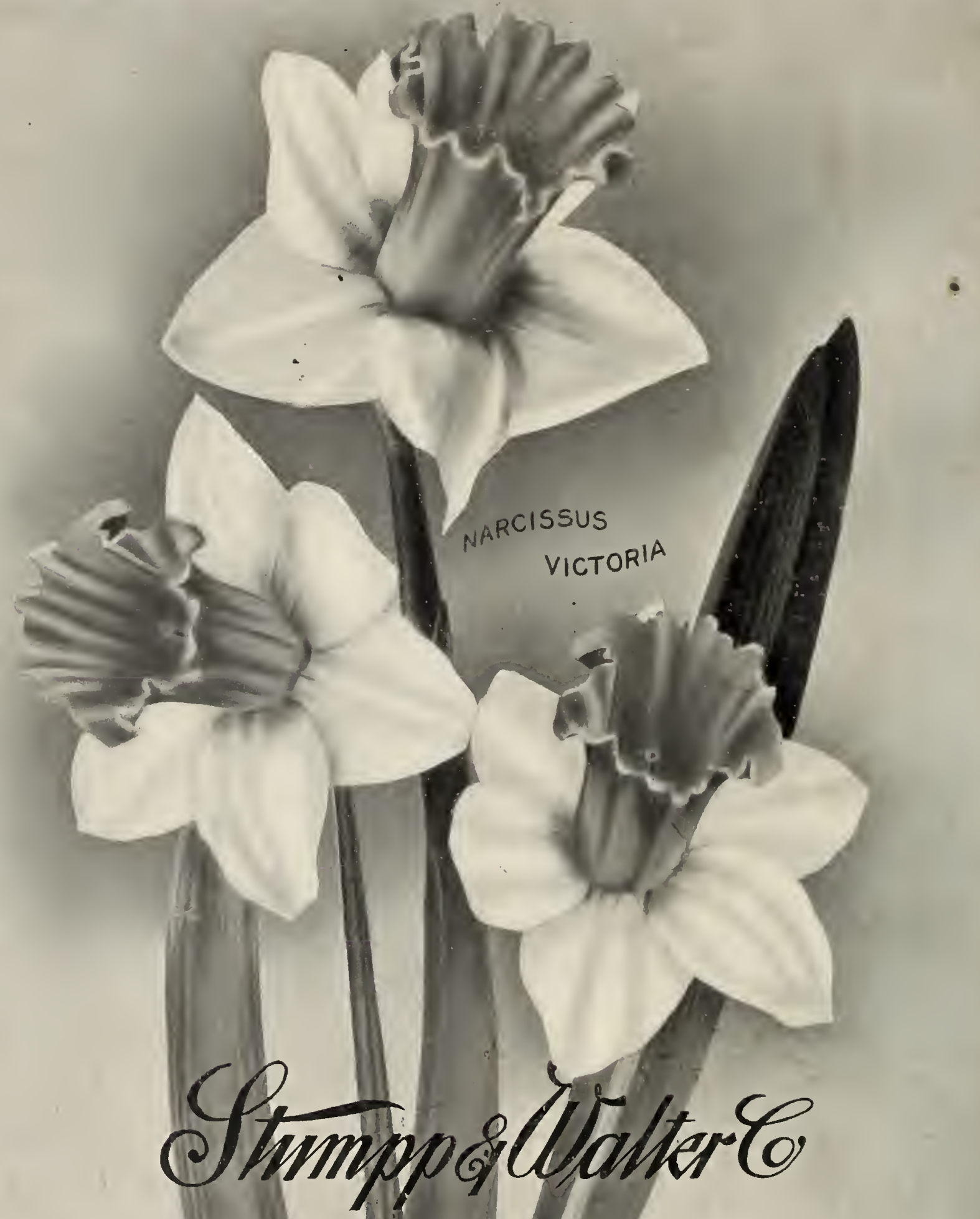

50 BARCLAY STREET,

NEW YORK 